\title{
The genera that never were: The impact of Janeia and Janacekia on phyletic and taxonomic relations within the Solemyidae (Bivalvia: Protobranchia)
}

\author{
Jack Bowman Bailey
}

\begin{abstract}
Proposed taxonomies of the Solemyoidea remain conflicted, particularly regarding the familiar genera, Solemya and Acharax, whose close phyletic kinship has been obscured by: 1) imperfect understanding of the chronological morphogenesis of diagnostically important ligament support structures, and 2) misconceptions triggered by two problematic Paleozoic genera, Janeia and Janacekia, including the prevalent mischaracterization that the primary ligament in Janeia was located in an internal chondrophore. Whereas Janacekia and certain Janeia are synonyms of Acharax, other alleged Janeia are shown to be clinopisthins such as Dystactella and Clinopistha. Morphological analysis supports DNA studies suggesting Acharax and Solemya are monophyletic, thereby challenging recent taxonomies placing them in separate families or superfamilies. The primary ligaments of Acharax and Solemya are basically similar (opisthodetic, parivincular, attached at nymphae), the main differences being placement: external in Acharax but slightly internal (submarginal) in Solemya. Character analyses suggest the external nymphae of Acharax are plesiomorphic, arising by the Early Devonian, whereas the submarginal placement of the nymphae in Solemya is shown to be a Mesozoic apomorphy involving depression and secondary enclosure of the ligament and nymphae by a shelly outer layer. Nymphal enclosure has had two concomitant effects: 1) dorsal occlusion of the posterior adductor muscle; 2) fusion of the nymphae to internal buttresses that plesiomorphically functioned as simple reinforcement for the anterior margin of the posterior adductor muscles whereas, by exaptation, they become apomorphically modified to serve as supporting braces for the submarginal nymphae by dorsally uniting with them.
\end{abstract}

Jack Bowman Bailey. Department of Earth, Atmospheric and Geographic Information Sciences Western Illinois University, 1 University Circle, Macomb, IL 61455 USA. jb-bailey@wiu.edu

Keywords: Solemyidae; Acharax; Solemya; Janeia; Janacekia; bivalve classification

Bailey, Jack Bowman. 2021. The genera that never were: The impact of Janeia and Janacekia on phyletic and taxonomic relations within the Solemyidae (Bivalvia: Protobranchia). Palaeontologia Electronica, 24(1):a12. https://doi.org/10.26879/945 palaeo-electronica.org/content/2021/3309-on-janeia-and-janacekia 


\section{INTRODUCTION}

\section{Overview}

Bivalve lineages are well known for evolutionary stasis, often showing only minor oscillations in shell morphology occurring over millions of years (Stanley and Yang, 1987). Throughout their roughly 475-million-year history, the Solemyidae have remained among the most conservative of bivalves in both morphology and chemosymbiotic autecology (Seilacher, 1990; Cope, 2000; Imhoff et al., 2003; Kiel, 2010; Bailey, 2011). Consequently, many fossil species have been reasonably placed within two ancient and enduring genera, Solemya Lamarck, 1818, and Acharax Dall, 1908. Commonly called "awning shells", both genera uniquely share the same thickened frill of radially pleated periostracum extending well beyond the calcified shell margins (e.g., see various figures of Pojeta, 1988; Dell, 1995; Taylor et al., 2008; Oliver et al, 2011; Walton, 2015). The frill is an ancient character well documented in Pennsylvanian Acharax (see Bailey, 2011) with possible traces in an Ordovician antecedent, Ovatoconcha Cope, 1996 (see Cope, 2000, 2002).

In Solemya, minor differences in the ligament are used as a basis for division into subgenera. Although the resulting system has been confusing and its application often inconsistent, several studies (Pojeta, 1988; Carter, 1990; Taylor et al., 2008; Kamenev, 2009; Bailey, 2011) have provided much needed clarification. However, significant problems remain especially regarding the precise relation between Solemya and Acharax, whose intimate phyletic ties have been obscured by: 1) incomplete understanding of the chronological morphogenesis of the diagnostically important ligaments and their associated structures; and 2) confusion generated through the widespread and persistent use of the ambiguous names, Janeia King, 1850 and Janacekia Růžička and Řehoř, 1978 along with their attendant mischaracterizations of Paleozoic solemyids.

\section{Terminology, Figure Scales, and Repositories}

Due to inherent ambiguities, certain traditional terms used to describe the bivalve shell and its orientation are sometimes replaced herein by unbiased and directionally neutral terms proposed by Bailey (2009, 2011; see also Carter et al., 2012).
This system was designed to be useful in describing fossil bivalve specimens where recognition of the anterior and posterior ends of the shell is problematic due either to differences of opinion or data insufficiency. The system is especially useful in the present study inasmuch as edmondioids and several other posteriorly elongate fossil taxa have been historically confused with solemyids, all of which are anteriorly elongate.

Beginning with Children (1823, p. 300) the archaic spelling "Solenomya" [nomen vanum] and its variation, "Solenimya" were widely used by early authors in lieu of Lamarck's (1818, p. 488) original spelling, Solemya. To avoid confusion in the text, uncorrected orthographies are here limited to the Appendix.

Illustrations of early authors reproduced herein are 600 dpi grayscale digital scans of the original physical publications, not screen captures borrowed from various online sources. Because authors rarely mention the size or dimensions of illustrated specimens, 1 centimeter bar scales shown in the figures herein were measured directly from the original printed sources.

Repository abbreviations are as follows: BGS British Geological Survey, Keyworth, Nottinghamshire, UK; UM - University of Missouri, Columbia, MO; USNM - United States National Museum of Natural History, Washington, D.C. The specimen E1114 is in the collections of the Sedgwick Museum, Cambridge, UK.

\section{SOLEMYA, ACHARAX, AND THE SOLEMYIDAE}

\section{Ligament and Support Structures in Solemya and Acharax}

In the Solemyidae an understanding of the ligament and its supporting structures is fundamental in ascertaining the systematic relations among constituent genera. In the familiar solemyids Acharax and Solemya, the ligament is amphidetic, composed of two principal components: 1) a dorsally arched, parivincular portion posterior to the beaks (= primary ligament) consisting of an inner fibrous layer (Figure 1, Igf) attaching on each side at insertion grooves, bordered by narrow ridges (i.e., nymphae) (Figure 1, ne, ns) that function as attachment sites for an outer lamellar layer (Figure 1, |gl); and 2) an anterior extension (not shown) of the lamellar outer layer in front of the beaks that is often asym- 


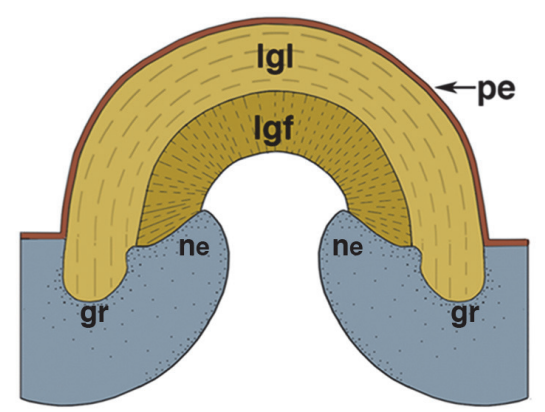

A

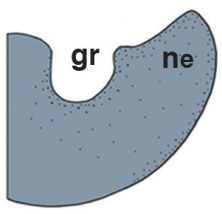

B

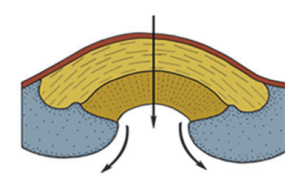

C

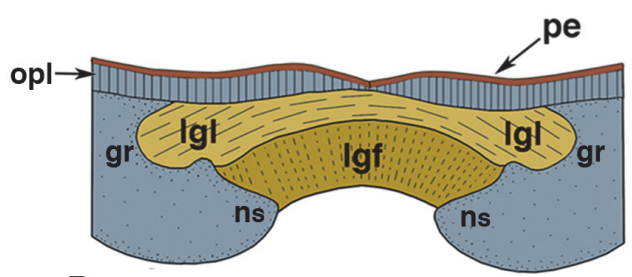

D

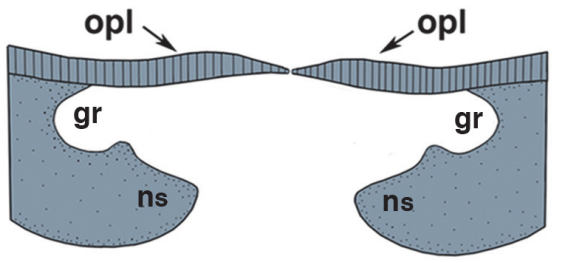

E

FIGURE 1. Diagrammatic transverse sections comparing the posterior portion of the ligament and nymphae of $A c h a-$ rax and Solemya. A, the upward-arching (parivincular) external ligament and nymphae, i.e., the plesiomorphic condition as seen in Acharax. (Drawing based on Carter, 1990, fig. 17D; Bailey, 2011, pl. 4, figs. 4-6; and Taviani et al., 2011, fig. 5). B, external nymphae of Acharax with the ligament removed. When the ligament is not preserved, the nymphae are visibly separated by an internymphal gap. $\mathbf{C}$, hypothetical intermediate condition showing beginning stages of ligament depression and inward rotation of nymphae (arrows). D, submarginal ligament and nymphae - the apomorphic condition seen in Solemya. The depressed ligament is secondarily overgrown by a shelly outer prismatic layer. (After Carter, 1990, fig. 17A.) E, the submarginal nymphae of Solemya with the ligament removed. Notice the outer secondary layer that covers the former internymphal gap. Abbreviations: ne - external nymph, ns - submarginal nymph gr - ligament insertion groove, ig - internymphal gap, lgf - fibrous inner layer of ligament, Igl - lamellar outer layer of ligament, pe - periostracum, opl - outer (secondary) prismatic shell layer.

metrically attached between the left and right valves (see Carter, 1990, p. 174; Bailey, 2011, p. 19).

In Acharax the primary ligament is external, attaching at external nymphae (Figures 1, 2, ne) and insertion grooves (Figure 1, gr). However, in all subgenera of Solemya the primary ligament is sunken to a shallow internal (= submarginal) position immediately below the posterodorsal margins of the shell. There it is attached to a pair of submarginal nymphae and flanking grooves (Figure 1, ns, gr and Figure 2, ns), each supported at its anterior end by attachment to a ridge-like buttress (= rib, ridge, prop, or clavicle of various authors), i.e., a narrow thickening of the valve that extends along the anterior margin of the posterior adductor muscle (Figure 2, btc). Submarginal nymphae in Solemya are conventionally termed chondrophores (e.g., Dall, 1908) thus obscuring their homological relation to external nymphae. Unlike Solemya, the internal buttress (Figure 2, bts) of Acharax is not attached to nymphae and is variable in development, sometimes prominent but often weak or obsolescent. Peripheral thickenings of adductor attachment sites in other bivalve taxa (Bailey, 1983; Taylor et al., 2008) suggest that the buttress in Acharax functions in part for added reinforcement of the thin valve along the posterior adductor margin (Bailey, 2016).

Because of its remarkable similarities to Solemya in gross morphology, Acharax was originally recognized as a subgenus of Solemya (see Dall, 1908, p. 2). Even the diagnostic primary ligament, aside from its external vs. submarginal location, is fundamentally similar in the two genera (Figure 1; see also Bailey, 2011, text-fig. 2). The homologies seem obvious. Together, Acharax and Solemya arguably form a monophyletic group (i.e., clade) in which the external ligament and nymphae of Acharax, the probable plesiomorphic condition (Figure $1 \mathrm{~A}-\mathrm{B})$, later achieved submarginal (apomorphic) status in Solemya through depression of the nymphae and ligament below the posterodorsal margin (Figure 1C-E), along with attendant overgrowth of a thin outer prismatic layer (Carter, 1990, fig. 17; Bailey, 2011; Carter, et al., 2012, fig. 216). As 


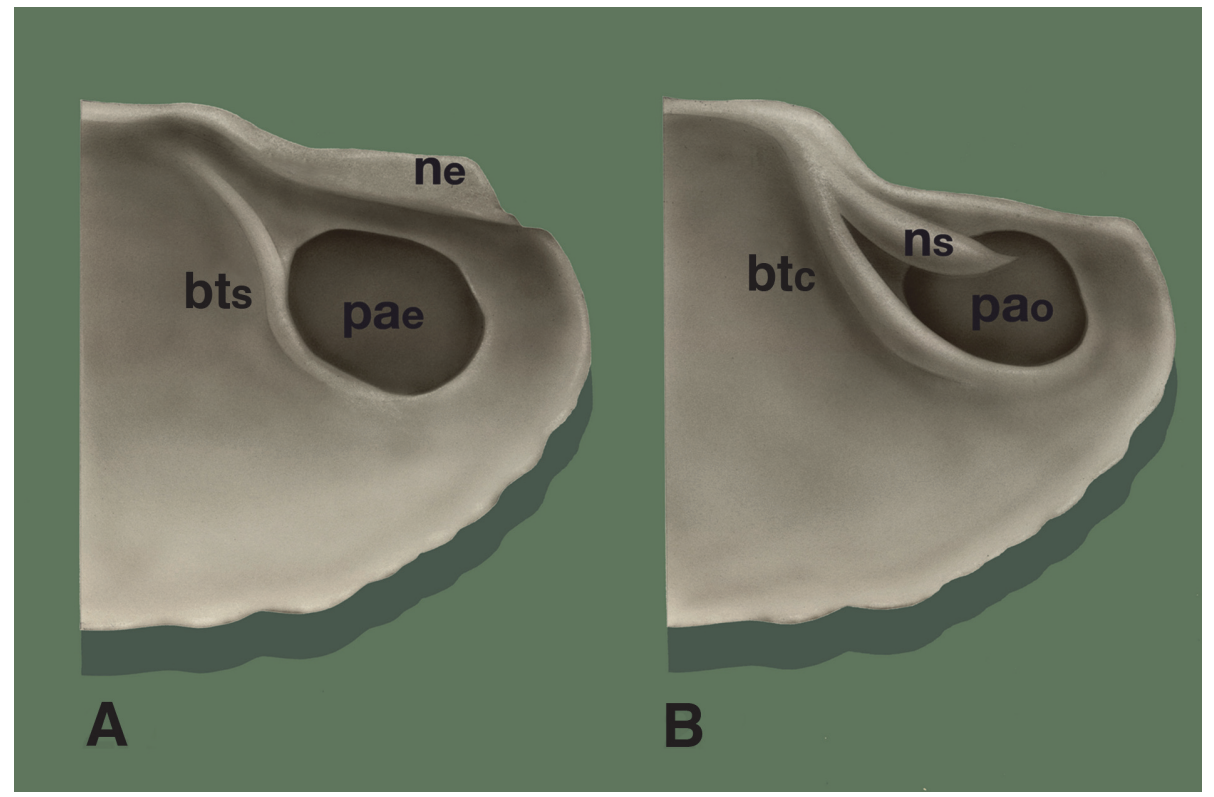

FIGURE 2. Comparative internal views of the posterior portion of the right valves of Acharax (A) and Solemya (B) showing character states of the nymphae, internal buttresses and posterior adductor scars. In Acharax the nymph (ne) is external, the condition of the internal buttress is simple (bts), and the condition of the posterior adductor muscle scar is entire (pae). In Solemya, depression of the nymph to a submarginal position (ns) results in a compound buttress (btc) and an occluded posterior adductor scar (pao).

noted by Waller (1998, p. 19), the outer prismatic layer (Figure 1, opl) covering the ligament "is a secondary [apomorphic] feature that is not present in the earliest ontogeny of the dissoconch...nor in the earliest members of the Solemyoidea and Solemyidae." Depression of the nymphae may have been facilitated by the natural tendency of the thin shells and periostracum (Figure 1, pe) to crack and repair in the umbonal and ligamental regions during growth (Waller, 1990; Bailey, 2011).

In Solemya, depression of the nymphae below the hinge margin has resulted in: 1) fusion of the anterior end of each nymph directly to the internal buttress such that the function of the buttress becomes altered by exaptation from an original one of reinforcing the attachment site of the posterior adductor muscle along its anterior border (Figure $2 \mathrm{~A}$, bts) to one of serving as a supporting brace or prop for the submarginal nymph (Figure 2B, btc; see also Bailey, 2016); and 2) dorsal occlusion, either by embayment, truncation, or intersection, of the posterior adductor muscle by the nymph. In the case of intersection, the posterior adductor partially continues around the obstructing nymph, passing posteriorly above it (Figure 2B, pao). The resulting cross-cutting relationship firmly establishes the submarginal posterior ligament and nymphae in Solemya as apomorphic traits (see also pl. 4, fig. 2 of Pojeta, 1988, and figs. 3h, 3i of Hryniewicz et al., 2014).

\section{Proxy Characters Linked to Nymphal Placement}

In Acharax and Solemya, nymphal placement has a significant influence on the internal morphology of the shell. If neither nymphae nor ligament are preserved, the two genera may nevertheless be distinguished from each other in internal molds or incomplete specimens so long as traces of the buttresses and posterior adductor scars are present. Serving as proxies of nymphal placement, two functionally linked character states are here designated as follows: Where the nymphae are external (a plesiomorphy), the buttress will be simple and the posterior adductor will be entire. Where the nymphae are submarginal (an apomorphy), the buttress will be compound, and the posterior adductor will be occluded. In Acharax: 1) the buttress is simple (Figure 2A, bts), that is, from the anterior limit of the posterior adductor scar, it extends dorsally to the underside of the umbo without any evident attachment to a nymph; and 2) in the absence of a submarginal nymph the posterior adductor muscle is entire, that is, whole and unobstructed (Figure 2A, pae). The condition is reversed in Solemya: 1) the buttress is compound, that is, it adjoins the anterior terminus of the sub- 

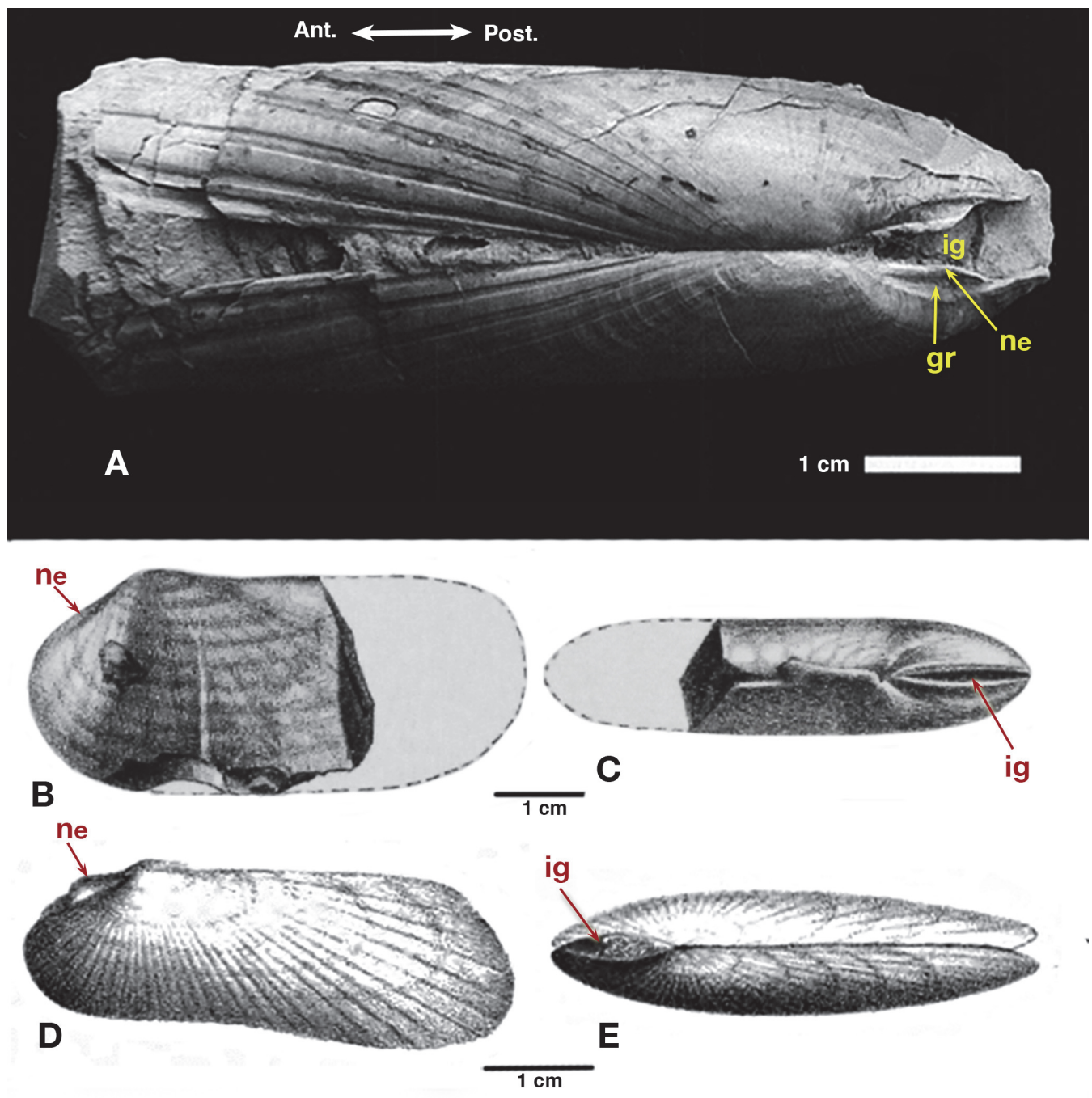

FIGURE 3. Internymphal gaps in fossil examples of Acharax. A, Acharax doderleini (Mayer, 1861), Pliocene of Italy; dorsal view showing external nymphae and ligament insertion grooves separated by internymphal gap that in life is covered by the ligament. In Solemya, the gap is secondarily closed off by the addition of a thin, outer prismatic shell layer. (Photo by permission, Taviani et al., 2011, fig. 5; yellow arrows with notations added here.) B-E, Solemya puzosiana de Koninck, 1842, Lower Carboniferous of Belgium. B, right lateral view of an incomplete articulated specimen (de Koninck, 1885, pl. 23, fig. 33). C, same specimen in dorsal view (de Koninck, 1880, pl. 23, fig. 34), reversed, anterior at left. D, right lateral view of an articulated specimen (de Koninck 1842, pl. 5, fig. 2b). E, same specimen in dorsal view (de Koninck 1842, pl. 5, fig. 2a). Hind (1900, p. 439) synonymized this specimen with Solemya primaeva Phillips, 1836, the type species of Janeia King, 1850. Internymphal gaps shown in de Koninck's figures are consistent with Acharax but not Solemya. Red arrows with notations added here. Abbreviations: ne - external nymph; ig internymphal gap; gr - ligament insertion groove.

marginal nymph, the resulting configuration of the two forming a "7" shape (Figure 2B, btc); and 2) the posterior adductor is thereby occluded, becoming dorsally truncated, embayed, or intersected by the nymph (Figure 2B, pao).

One additional proxy needs to be discussed. Among fossil solemyids, paired external nymphae are often visibly separated by a narrow space whenever the primary ligament is not preserved. In error, Hind (1900, p. 442) referred to the space as a "slit for the ligament." Herein termed the internymphal gap (Figures 1B, 3A-E, ig), it is a character seen in living and fossil Acharax but not in Solemya. In his original diagnosis Dall (1908, p. 2) referred to it thusly: "Ligament opisthodetic, wholly external, visible internally only where it crosses the gap between the margins of the valves." In Acharax, the internymphal gap is cov- 


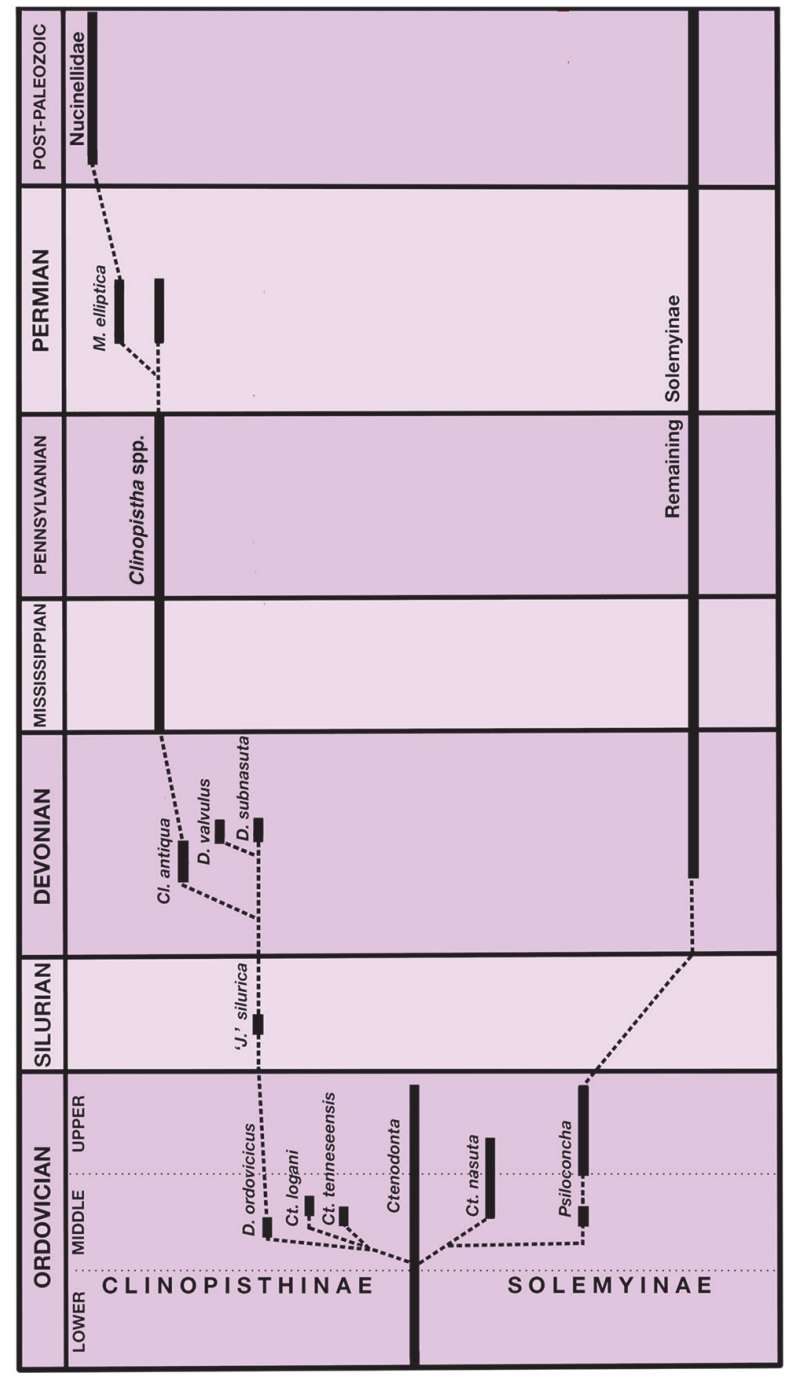

A

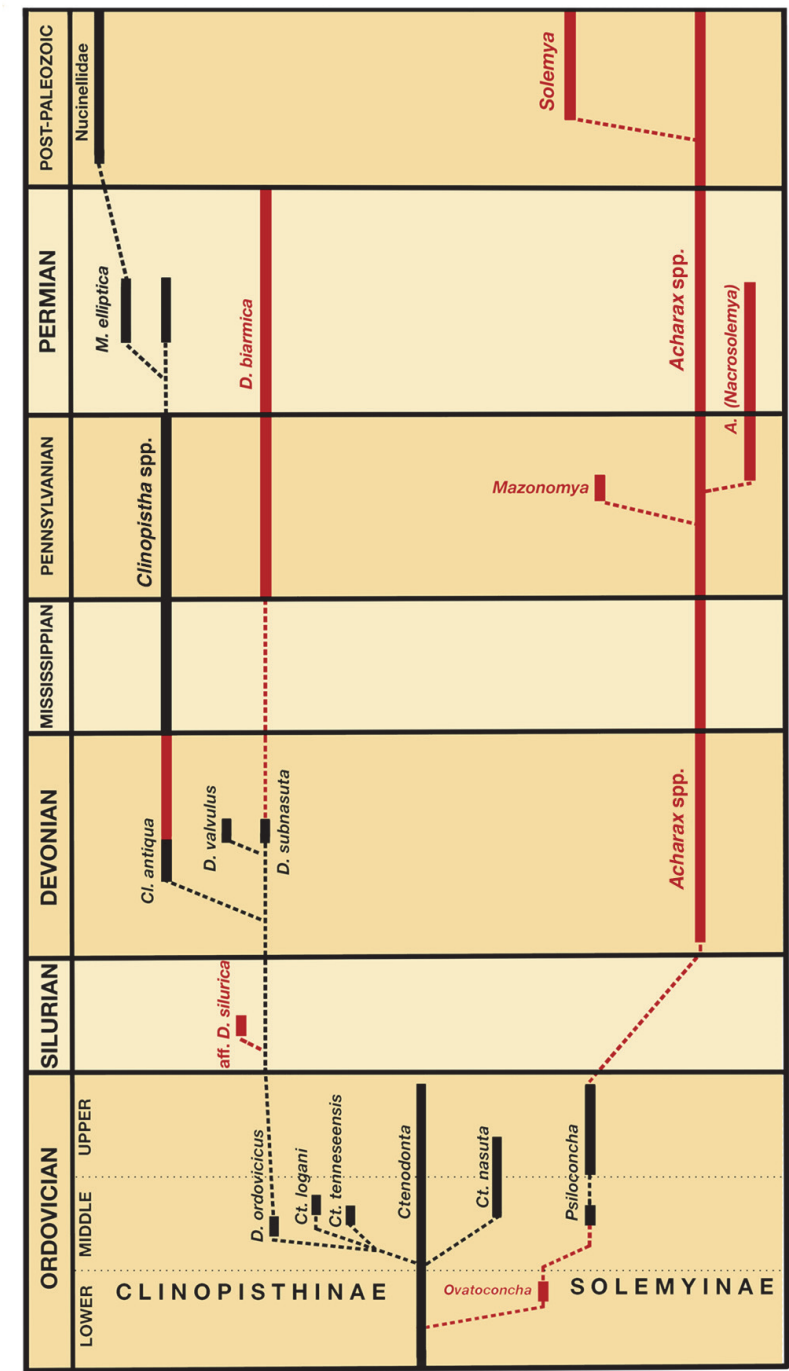

B

FIGURE 4. Phyletic schemes and biostratigraphic ranges (solid bars) of Paleozoic solemyoid genera. A, phyletic scheme of Pojeta (1988, fig. 3) postulating derivation of the Clinopisthinae and Solemyinae from nuculoid ancestors (i.e., Ctenodonta). B, proposed modifications (in red) of Pojeta's scheme based on studies herein. Abbreviations of generic names: $A$. = Acharax; $C l$. = Clinopistha; Ct. = Ctenodonta; $D$. = Dystactella; ' $J$.' = Janeia; and $M$. = Manzanella.

ered in life by the arch of the external ligament and is thereby visible only when the ligament is not preserved. In contrast, the internymphal gap is missing in Solemya because the nymphae are submarginal and the former gap is secondarily covered over by the aforementioned outer prismatic shell layer (Figure 1D-E, opl). In addition to Acharax, the internymphal gap (a probable symplesiomorphy) is observed in other fossil solemyid genera with external nymphae including both Clinopistha Meek and Worthen, 1870, and Dystactella Hall and Whitfield, 1872.

\section{Solemyid Origins and Phylogeny}

Parivincular ligaments with supporting nymphae are key characters used in Pojeta's (1988) proposed phylogeny of fossil and extant Solemyidae (Figure 4A). Pojeta (1988) and Waller (1990, 1998) posited that these characters were acquired from nymph-bearing ctenodontid nuculoid ancestors such as Ctenodonta nasuta (Hall, 1847) and, especially, Ctenodonta tennesseensis Pojeta, 1988, which, aside from the taxondont hinge, is strikingly similar to the early solemyid Dystactella 
Hall and Whitfield, 1872. Strong phylogenetic connections of the solemyids and nuculoids are supported by numerous other studies (e.g., Carter et al., 2000; Carter, 2001; Giribet and Distel, 2003; Giribet, 2008; Bailey, 2011; Carter et al., 2011; Bieler et al., 2014). However, based on stratigraphic occurrences Cope (2002) suggested that these characters might have arisen independently in the two groups. Whereas the solemyid Ovatoconcha is dated as late Early Ordovician, ligamental nymphae do not occur in ctenodontids until the Middle Ordovician. Alternatively, Cope also posited that nymphae could be persistent characters derived from earlier, as yet undocumented ctenodontid stock. Indeed, persistent solemyid traits are fairly common among much later nuculoids, for example, in Spathelopsis oakvalensis Peck, Bailey, Heck, and Scaiff, 2009 from the Mississippian of West Virginia (see Peck et al., 2009, p. 959; Bailey, 2011, p. 14).

Pojeta's (1988, fig. 3) phyletic scheme divided the Solemyidae into two sister subfamilies, the Clinopisthinae and the Solemyinae (Figure 4A). With the exception of Solemya, external placement of the nymphae and ligament is broadly shared in both subfamilies. Among the Solemyinae it occurs in Psiloconcha Ulrich, 1894 (Ordovician), Acharax (Devonian-Holocene), and Mazonomya Bailey, 2011 (Pennsylvanian). Among the Clinopisthinae, it occurs in Clinopistha Meek and Worthen, 1870 (Devonian-Permian) and Dystactella Hall and Whitfield, 1872 (Ordovician-Permian). Thus, it is likely to represent the primitive (symplesiomorphic) condition for the Solemyidae as a whole. In contrast, the submarginal ligament structure of Solemya is unique, representing a derived (autapomorphic) condition evidently not occurring prior to the Mesozoic (Figure 4B). Although ligament and nymphae are as yet unknown in Ovatoconcha, the genus is a near match for its possible congener, Psiloconcha with respect to: 1) shell profile, aspect ratio and shell gapes; 2) umbonal placement and elevation; 3) small size and high placement of the posterior adductors to accommodate the underlying hypertrophied gills and hypobranchial gland; and 4) pyriform outline and elevated placement of the anterior composite (adductor/visceral retractor) scars (Bailey, 2011, p. 12). Radial elements in the prosopon are not well developed in either genus, i.e., weak in Ovatoconcha and mostly lacking in Psiloconcha.

\section{The Problem of Range}

In order to establish a convincing phylogenetic derivation of Solemya from Acharax ancestry, the geologic timing of the split must be consistent with the foregoing character analysis.

The Y-shaped burrows of the ichnogenus Solemyatuba Seilacher, 1990 occur as early as the Ordovician (Seilacher, 1990). Although they are usually attributed to Solemya, comparable burrows are also associated with Acharax (Stanley, 1970, Campbell et al., 2006; Ros-Franch et al., 2014). Thus, their occurrence cannot be attributed to a particular genus.

Early authors, including Beushausen (1895), Zittel (1913), Quenstedt (1930), Shimer and Shrock (1944), as well as more recent authors, notably Cox (1969), gave the stratigraphic range of Solemya as Devonian-Holocene under the apparent misapprehension that the submarginal ligament and compound buttress were primitive characters, whereas the external ligament and simple buttress of Acharax were tacitly regarded as later derivations. For example, Cox (1969) regarded Acharax as a later genus with a verified range limited to Miocene-Holocene. However, Pojeta (1988) subsequently emended the range of each genus thusly: For Solemya, Upper Pennsylvanian-Holocene; and for Acharax, Lower Permian-Holocene, (with a dubious Middle Devonian occurrence). Pojeta's basis for concluding that Solemya occurred as early as the Upper Pennsylvanian was a single specimen, "Solemya sp." (USNM 415967), from the Hertha Limestone, Erie, Kansas (Pojeta, 1988, pl. 23, figs. 5-8). However, this specimen is a probable Acharax because the alleged free ends of the "chondrophores" shown in his figure 8 are probably the compressed and broken termini of external nymphae, a conclusion supported by his figure 5 of the same specimen showing: 1) simple buttresses that dorsally reveal no indication of either added reinforcement or attachment to internal nymphae; and 2) posterior adductor scars that are entire, lacking the expected dorsal occlusion caused by submarginal nymphae.

Although the study of Dickins (1963), like that of Pojeta (1988), ostensibly provided support for the late Paleozoic occurrence of Solemya, Dickins himself was tentative regarding the final generic assignment of his material. His "Solemya" holmwoodensis Dickins (1963) from the Lower Permian of western Australia is herein assigned to Acharax inasmuch as the holotype and three paratypes show strong external nymphae as well as the anterior ligamental extension (Dickins, 1963, p. 60; pl. 7, figs. 1-9). Even a dorsally arched portion of the external parivincular ligament is preserved in the holotype (Dickins, 1963, pl. 7, fig. 2). In error, Hajkr 
et al. (1978, p. 14) transferred this species to the Sanguinolitidae Miller, 1877.

Contemporary studies support the view that Acharax arose much earlier than Cox (1969) had supposed. For example, Acharax has been reported from the Early Devonian of Arctic Canada (Bailey, 2011, 2016; Bailey and Prosh, 2016). In addition, there are Pennsylvanian occurrences in both Kentucky (Carter, 1990) and the Mazon Creek Lagerstätte of Illinois (Bailey, 2011). Furthermore, all of the Devonian-Permian examples of alleged Solemya (and its doppelgänger, Janeia King, 1850) reviewed herein have external ligament and nymphae like Acharax, whereas the submarginal ligament and associated compounding of the buttress of Solemya appear to be Mesozoic modifications (see Appendix; also Bailey, 2011, 2016).

Unverified examples of Solemya have been reported from the Permian (Ciriacks, 1963; Sterren and Cisterna, 2010) and Triassic (Conrad, 1870). Ciriacks $(1963$, p. 42, pl. 5, figs.12, 13) tentatively designated a nearly featureless internal mold of a possible solemyid as Solemya sp. (UM $5275=$ "S. radiata?" sensu Branson, 1930) from the Park City Formation, near Cody, Wyoming. Although Ciriacks (p. 42) described the specimen as "insufficiently preserved for specific identification", the form superficially resembles Dystactella. Sterren and Cisterna (2010, p. vi) reported an occurrence of Solemya from the Early Permian of Argentina, but they provided neither figure nor description. Con$\operatorname{rad}(1870, p .102)$ described the shell exterior and radial prosopon of "an obscure cast" he designated Solemya triasina Conrad, 1870, from the Triassic of Perkiomen Creek, Pennsylvania. However, data on the hinge and ligament are lacking, and no figure of the specimen, now lost, was provided.

Other studies place the earliest occurrence of Solemya in either the Jurassic (Coan et al., 2000; Imhoff et al., 2003; Neulinger et al., 2006) or Cretaceous (Dechaseaux, 1952). Hryniewicz et al. (2014) reported convincing examples of Solemya from Late Jurassic-Early Cretaceous hydrocarbon seeps of Spitzbergen. The silicon rubber casts of their (fig. 3h-i) internal molds of Solemya (Petrasma) cf. woodwardiana Leckenby, 1859 clearly show the compound buttress and occluded posterior adductor scar. It should be noted, however, that alleged "Solemya woodwardiana" reported by Duff (1978) from the Lower Oxford Clay (Middle Jurassic of England) is a possible Acharax. Although data on the posterior adductor is lacking, a simple buttress is evident. In addition, the butterflied specimen figured by Duff (1978, pl. 1, fig. 40) shows what appear to be traces of a deltoid parivincular ligament stretching across an internymphal gap with a possible nymph and insertion groove preserved in the right valve.

The accumulation of 18S rRNA gene sequence disparities (Neulinger et al., 2006) separating extant species of Acharax and Solemya seem consistent with a Mesozoic (possibly Jurassic) split. The timing of the split is interesting. Among the Bivalvia in general, the Mesozoic is associated with episodes of rapid expansion and diversification (Ros et al., 2012).

\section{Taxonomic Dissent}

Despite extensive study, solemyoid classification remains in dispute, noticeably in regard to the systematic relations of Solemya and Acharax (Table 1). Owing to the external ligament, Cox (1969) in Part N of the Treatise first elevated Solemya (Acharax) Dall from subgeneric to full generic status while adding, in error, the vesicomyid, Adulomya Kuroda, 1931 (i.e., see Amano and Kiel, 2011) to the Solemyidae and, unfortunately, giving full recognition to the problematic Janeia King, 1850 as a subgenus of Solemya.

Based on the ontogenetic expansion vector of the shell and underlying soft anatomy, Pojeta's (1988) landmark study argued for two main phyletic lines (Figure 4A) within the Solemyidae, thereby subdividing the Solemyidae into two subfamilies: 1) the Solemyinae for anteriorly elongated solemyids with "barely discernible" beaks and umbos (i.e., Solemya, Acharax, and Psiloconcha); and 2) the Clinopisthinae for anteroventrally elongated solemyids with more conspicuous umbos and beaks (i.e., Clinopistha and Dystactella). This system was followed by Bailey (2011) and used herein (see Figure 4B, Table 1 and Appendix).

Scarlato and Starobogatov (1979) split the order Solemyoida into two suborders, the Nucinellina and Solemyina. Emphasizing the relative significance of the submarginal vs. external ligament, they divided the Solemyina into two taxonomic divisions: 1) the Superfamily Solemyoidea/Family Solemyidae was proposed for genera with submarginal ligaments such as Solemya; and 2) the Superfamily Acharacoidea/Family Acharachidae was proposed for genera with an external ligament, including Acharax and, in error, the vesicomyid Adulomya (see Amano and Kiel, 2011). A similarly divided system was endorsed by Zardus (2002), Nevesskaja (2009), and Nevesskaja et al. (2013).

Maxwell (1988) likewise placed Acharax and Solemya in separate superfamilies, the Acharac- 
TABLE 1. Solemyoid classification schemes of various authors. Acharax and Solemya have been placed either in separate families (or superfamilies) or grouped together within the same family (or subfamily).

\section{Cox, 1969}

Class BIVALVIA Linné, 1758

Subclass CRYPTODONTA Neumayr, 1884

Order SOLEMYOIDA Dall, 1889

Superfamily SOLEMYOIDEA Adams and Adams, 1857 (1840)

Family SOLEMYIDAE Adams and Adams, 1857 (1840)

(Includes Solemya and Acharax; Clinopistha [= Dystactella] placed in

Ctenodontidae Wöhrmann)

\section{Scarlato and Starobogatov, 1979}

Class BIVALVIA Linné, 1758

Superorder PROTOBRANCHIA Pelseneer, 1889 (= Nuculoida Dall, 1889)

Order SOLEMYIDA Newell, 1965

Suborder SOLEMYINA Newell, 1965 (= Solenomyina Dall, 1889)

Superfamily ACHARACOIDEA Scarlato et Starobogatov, 1979

Family ACHARACIDAE Scarlato et Starobogatov, 1979

(Acharax placed here)

Superfamily SOLEMYOIDEA H. Adams et A. Adams, 1857

Family SOLEMYIDAE H. Adams et A. Adams, 1857

(Solemya placed here)

Suborder NUCINELLINA Scarlato et Starobogatov, 1971

Superfamily AFGHANODESMATOIDEA Scarlato et Starobogatov, 1979

Family AFGHANODESMATIDAE Scarlato et Starobogatov, 1979

Superfamily MANZANELLOIDEA Chronic, 1952

Family MANZANELLIDAE Chronic, 1952

Family NUCINELLIDAE Vokes, 1956

Superfamily HUXLEYOIDEA Scarlato et Starobogatov, 1971

Family HUXLEYIIDAE Scarlato et Starobogatov, 1971

Allen and Hannah, 1986

Class BIVALVIA Linné, 1758

Subclass PROTOBRANCHIA Pelseneer, 1889

Order SOLEMYOIDA Dall, 1889

Family SOLEMYIDAE Gray, 1840

(Includes both Solemya and Acharax)

Family NUCINELLIDAE Vokes, 1956

Maxwell, 1988

(Class BIVALVIA)

(Subclass PROTOBRANCHIA)

Order SOLEMYOIDA Dall, 1889

Suborder SOLEMYINA Dall, 1889

Superfamily SOLEMYOIDEA Gray, 1840

Family SOLEMYIDAE Gray, 1840

(Solemya placed here)

Family ACHARACIDAE Scarlato and Starobogatov, 1979

(Acharax placed here) 
TABLE 1 (continued).

Suborder NUCINELLINA Scarlato and Starobogatov, 1971

Superfamily MANZANELLOIDEA Chronic, 1952

Family MANZANELLIDAE Chronic, 1952

Cope, 1996

Class BIVALVIA Linnaeus, 1758

Subclass LIPODONTA Cope, 1995

Order SOLEMYOIDA Dall, 1889

Superfamily SOLEMYOIDEA Adams and Adams, 1857

Family SOLEMYIDAE Adams and Adams, 1857

Pojeta, 1988

Class PELECYPODA Goldfuss

Subclass PALAEOTAXODONTA Korobkov

(= Subclass PROTOBRANCHIA Pelseneer)

Superfamily SOLEMYOIDEA Adams and Adams

Family SOLEMYIDAE Adams and Adams

Subfamily SOLEMYINAE Adams and Adams

(Includes both Solemya and Acharax)

Subfamily CLINOPISTHINAE Pojeta, 1988

(includes both Clinopistha and Dystactella)

Superfamily NUCINELLOIDEA Vokes, 1956

Family NUCINELLIDAE Vokes, 1956

Family MANZANELLIDAE Chronic, 1952

Amler, 1999

(Class BIVALVIA)

Subclass LIPODONTA (Iredale, 1939) Cope, 1995

Order SOLEMYOIDA Dall, 1889

Superfamily SOLEMYOIDEA (Adams and Adams, 1857) Gray, 1840

Family SOLEMYIDAE (Adams and Adams, 1857) Gray, 1840

(Solemya placed here)

Family JANACEKIIDAE Růžička and Řehoř, 1978

(Janacekia placed here)

Family ACHARACIDAE Scarlato and Starobogatov, 1979

(Acharax placed here)

Nevesskaja, 2009; Nevesskaja et al., 2013

Class BIVALVIA

Superorder PROTOBRANCHIA Pelseneer, 1889

Order SOLEMYIDA Newell, 1965

Superfamily SOLEMYOIDEA H. et A. Adams, 1857

Family SOLEMYIDAE H. et A. Adams, 1857

(Solemya placed here)

Superfamily ACHARACOIDEA Scarlato et Starobogatov, 1979

Family ACHARACIDAE Scarlato et Starobogatov, 1979

(Acharax placed here)

Superfamily MANZANELLOIDEA Chronic, 1952 
TABLE 1 (continued).

Family MANZANELLIDAE Chronic, 1952

Family NUCINELLIDAE Vokes, 1956

Beiler et al., 2010

Class BIVALVIA Linnaeus, 1758

Subclass PROTOBRANCHIA Pelseneer, 1889

(= Sublcass PALAEOTAXODONTA Korobkov, 1954)

Order SOLEMYOIDA Dall, 1889

Superfamily MANZANELLOIDEA Chronic, 1952

Family MANZANELLIDAE Chronic, 1952

Superfamily SOLEMYOIDEA Gray, 1840

Family SOLEMYIDAE Gray, 1840

Subfamily SOLEMYINAE Gray, 1840

(= Family JANACEKIIDAE Růžička and Řehoř, 1978)

(Includes both Solemya and Janacekia)

Subfamily ACHARACINAE Scarlato and Starobogatov, 1979

(Acharax placed here)

Subfamily CLINOPISTHINAE Pojeta, 1988

\section{Carter et al., 2011}

Class BIVALVIA Linnaeus, 1758

Subclass PROTOBRANCHIA Pelseneer, 1889

(= Subclass PALAEOTAXODONTA Korobkov, 1954)

Superorder NUCULIFORMII Dall, 1889

(= Superorder FOLIOBRANCHIA Ménégaux, 1889)

Order SOLEMYIDA Dall, 1889

Superfamily SOLEMYOIDEA Gray, 1840

Family SOLEMYIDAE Gray, 1840

Subfamily SOLEMYINAE Gray, 1840

(Includes both Solemya and Acharax)

Subfamily JANACEKIINAE Růžička and Řehoř, 1978

(Janacekia placed here)

Family CLINOPISTHIDAE Pojeta, 1988

Family CTENODONTIDAE Wöhrmann, 1893

Family OVATOCONCHIDAE Carter, 2011

\section{Bailey, 2011 (and herein)}

Class BIVALVIA Linnaeus, 1758

Subclass PROTOBRANCHIA Pelseneer, 1889

(= Subclass PALAEOTAXODONTA Korobkov, 1954)

Superorder NUCULIFORMII Dall, 1889

Order SOLEMYOIDA Dall, 1889

Superfamily SOLEMYOIDEA Gray, 1840

Family SOLEMYIDAE Gray, 1840

Subfamily SOLEMYINAE Gray, 1840

(includes both Solemya and Acharax)

Subamily CLINOPISTHINAE Pojeta, 1988

(includes both Clinopistha and Dystactella) 
oidea and Solemyoidea, respectively, whereas Amler (1999) recognized only one superfamily, the Solemyoidea made up of three families, the Solemyidae, the Janacekiidae, and the Acharacidae.

Bieler et al. (2010) combined and modified the classifications of both Pojeta (1988) and Scarlato and Starobogatov (1979) by dividing the Solemyidae into three subfamilies, the Clinopisthinae, the Acharacinae, and the Solemyinae, the latter considered as a synonym of the Janacekiidae Růžička and Řehor 1978 . However, this system is problematic in that it results in the division of the AcharaxSolemya clade into two paraphyletic subgroups. Furthermore, treating the Janacekiidae as a synonym of the Solemyinae is antithetical because the namesake, Janacekia Růžička and Řehoř, 1978, has the external ligament and nymphae like Acharax but unlike Solemya, as discussed further below.

Carter et al. (2011) proposed dividing the order Solemyida into two superfamilies, the Solemyoidea and the Manzanelloidea. In this system, the Solemyoidea comprises four families: the Solemyidae, consisting of the subfamilies Solemyinae (containing both Acharax and Solemya), as well as the Janacekiinae, Clinopisthidae, Ctenodontidae, and Ovatoconchidae. However, because Janace$k i a$ is herein accepted as a junior synonym of Acharax, the Janacekiinae becomes superfluous. In addition, Ovatoconcha, because of its similarities to Psiloconcha, may arguably be placed in the Solemyinae.

If, indeed, as posited herein, Solemya was derived from Acharax ancestors by, perhaps, midMesozoic times through depression of the primary ligament and nymphae to a submarginal position, the two genera are monophyletic, a conclusion independently corroborated by both Sharma et al. (2013) and Combosch et al. (2017) in each of their phylogenetic tests of molecular markers in the genomic DNA of Solemya and Acharax. The 18S rRNA analysis of these genera by Taylor et al. (2008) reached a similar conclusion. According to Mayr and Ashlock (1991) higher taxa should consist of monophyletic groups separated from groups of similar rank by a distinctive gap. Their understanding echoes Schenck's (1934, p. 55) classic criterion: "One basic principle is that a family should be monophyletic." When inherent misunderstandings associated with Janeia and Janacekia are eliminated, the morphologic and temporal gaps separating Acharax and Solemya are not only minimized, but also consistent with DNA studies. Thus, of the various systems described above, Pojeta's
(1988) taxonomic scheme combining both genera within a single subfamily (Solemyinae) remains a viable alternative to placement into separate (paraphyletic) superfamilies or families.

\section{THE JANEIA PROBLEM}

Key issues influencing the taxonomic debate are historical interpretations (sometimes incomplete or erroneous) of past authors regarding the placement of the primary ligament and its associated structures, specifically, the mistaken assumption that among Paleozoic Solemyidae, the primary ligament was placed internally, supported there by so-called "chondrophores" as in modern Solemya. This assumption has been largely based on a series of misapprehensions regarding a single illusory genus, Janeia.

\section{In Search of a Concept}

Janeia King (1850) may be justifiably regarded as a nomen dubium (Hryniewicz et al., 2017). Commenting on its ill-defined and confusing history, Pojeta (1988, p. 214) called it "a name looking for a concept." Nevertheless, Janeia continues to be widely applied in recent publications (e.g., Nevesskaja, et al., 2013) and many online databases, even though it is devoid of any essential meaning. Historically, the ongoing confusion began with King (1850) himself. In his celebrated monograph, The Permian Fossils of England, he first proposed the genus on page 177 of the text, but subsequently withdrew it in an appendix note (p. 246-247) of the same publication, concluding that Janeia and Solemya are synonymous. In addition, King's original diagnosis of Janeia is both ambiguous and inaccurate, reflecting not only a misunderstanding of the fossil material at hand but also a lack of familiarity with solemyid soft anatomy. In his diagnosis the anterior and posterior ends of the shell were reversed, and he mischaracterized the ligament (i.e., "cartilage") as "internal; attached to a considerable portion of, and a little within, the dorsal margin of the valves; dilated, and somewhat oval within the umbonal cavity; narrow and elongated behind [sic] it" (King, 1850, p. 177). The "considerable" dorsal attachment of the ligament possibly refers only to the secondary ligament, that is, the anterior extension of the ligament outer layer (seen in both Acharax and Solemya) that runs along much of the anterodorsal (longidorsal) length of the valves. The "somewhat oval" portion is more difficult to interpret; perhaps it refers to the variably developed subumbonal ligamental 
demipads seen in Solemya and some Acharax (see Bailey, 2011).

King $(1850$, p. 247$)$ reported that his withdrawal of Janeia was based on an evaluation of the anatomical and conchological figures of Solemya mediterranea Lamarck, 1818, as contained in Cuvier (1836, plate 115). Curiously, despite anatomical evidence to the contrary, King (1850, p. 247) persisted in his erroneous interpretation of shell orientation and criticized contemporary conchologists who disagreed. Despite King's withdrawal of Janeia, the name has had a lasting legacy inasmuch as it has been accepted by many subsequent authors who, in an attempt to salvage the concept, have ascribed to it additional characters far beyond those originally intended by King.

Historically, Janeia has been conceptually applied to Paleozoic solemyids having an internal (primary) ligament supported by internal "chondrophores" (= nymphae) as in extant Solemya. It must be emphasized that the nature of the primary ligament in Janeia is purely an unsupported assumption based on: 1) King's (1850, p. 177) mischaracterization of the ligament as internal; and 2) his subsequent conflation of Janeia with extant Solemya. Inasmuch as the name Janeia has been restricted to Paleozoic solemyids, the internal primary ligament has been accordingly presumed to be a primitive (plesiomorphic) character within the Solemyidae, whereas the external ligament in Acharax, is implicitly understood to be a postPaleozoic derived (apomorphic) condition. However, evidence suggests the opposite to be true, given the many published examples of Janeia showing evidence of an external primary ligament similar to Acharax (see Logan, 1967; Carter, 1990; Dickins, 1999; Bailey, 2011, and Appendix herein), whereas other examples of putative Janeia with external ligaments are assignable to either Dystactella or Clinopistha.

\section{Types and Archetypes}

Each of the species of Janeia originally proposed by King is evaluated below:

Janeia primaeva (Phillips, 1836). Logan's (1967) restudy of Janeia primaeva accepted the primary ligament as external, a conclusion later confirmed by Bailey (2011) who emended the name as Acharax primaeva (Phillips, 1836) (see Appendix).

As type species of Janeia, King (1850) selected Solemya primaeva Phillips, 1836 from the Lower Carboniferous (Tournaisian-Viséan) of Lowick, Northumberland, England (see Figure 5A), but he neither discussed it nor its relationship to his two other exemplars, Janeia biarmica (de Verneuil, 1845) from the Upper Permian Magnesian Limestone at Tunstall Hill and Humbledon Hill, Durham, England, and Janeia phillipsiana (King, 1848), allegedly from Humbledon Hill.

Solemya primaeva was evidently based on a single specimen. Phillips' (1836, p. 209, pl. 5, fig. 6 ) original treatment consists of an imprecise diagnosis and simple drawing. The putative holotype consisted of a composite mold with attached shell showing no evidence of the ligamental condition aside from the apparent non-occlusion of the posterior adductor scar, suggestive of an external ligament as in Acharax (Figure 5A). The specimen, originally stored in Phillips' personal collection, is lost, allegedly stolen by thieves (see Hind, 1896 footnote, p. 19). Portlock's (1843, p. 441) subsequent re-description $S$. primaeva was based on a single unfigured hypotype collected from an alternate location, i.e., Carboniferous shales of Aghaloo Parish, County Tyrone, Northern Ireland. Portlock's hypotype, much larger and more elongated than Phillips' holotype, was later illustrated by Hind (1900) (see Figure 5B). In the same study, Hind illustrated five additional specimens of $S$. primaeva (e.g., Figure 5C-D). One of these, a topotype (Figure 5C), was reproduced by Cox (1969, fig. B1.1a) in Part $\mathrm{N}$ of the Treatise where it was used as a principal basis for accepting Janeia as a valid subgenus. Unfortunately, the Treatise figure is mistakenly credited to Phillips (1836) rather than Hind (1900). Apart from the significant size disparity, the morphologic similarities of Hind's topotypic example (Figure 5C) and Portlock's hypotype (Figure 5B) are compelling. Both lack direct ligament data but show simple buttresses and entire posterior adductors characteristic of Acharax.

M'Coy (1855) approved of King's decision to withdraw Janeia in favor of Solemya in apparent agreement with King's presumption that the primary ligament is internal. However, he disagreed with King on shell orientation, asserting correctly that the valves are anteriorly elongate. On page 519 of the same work M'Coy provided a detailed description of an additional topotype he identified as Solemya primaeva Phillips, although the shell shape significantly differs from the aforementioned specimens of Hind. As shown in Figure 5E-F, it appears to be either an internal or composite mold with well-marked adductor scars and radial striae. As in Acharax, the posterior adductor scar is entire, and the internal buttress is weak and simple, extending along the anterior border of the posterior adductor and diminishing in relief as it approaches 


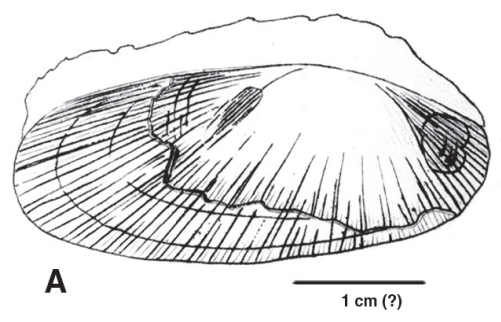

B
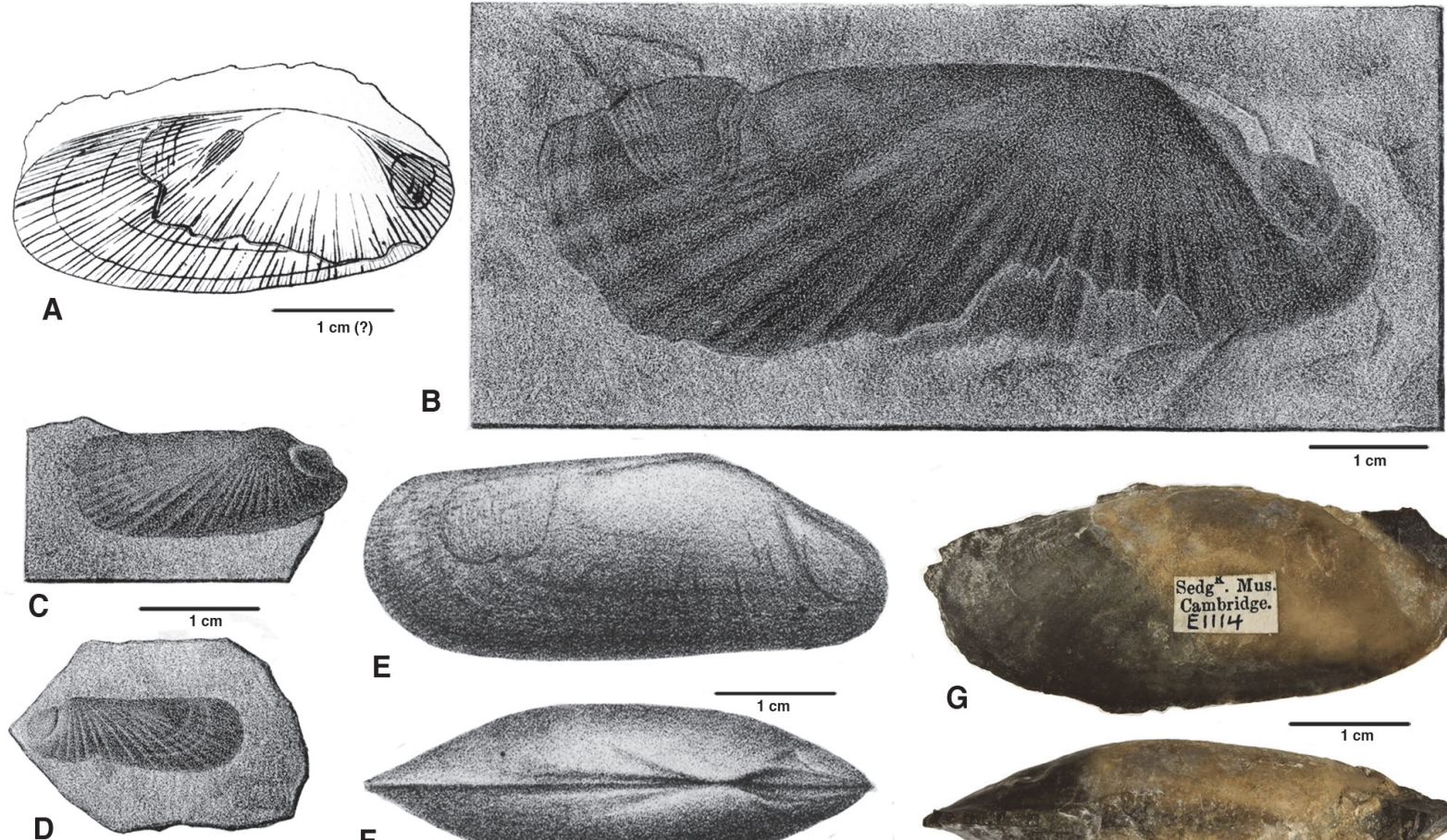

E
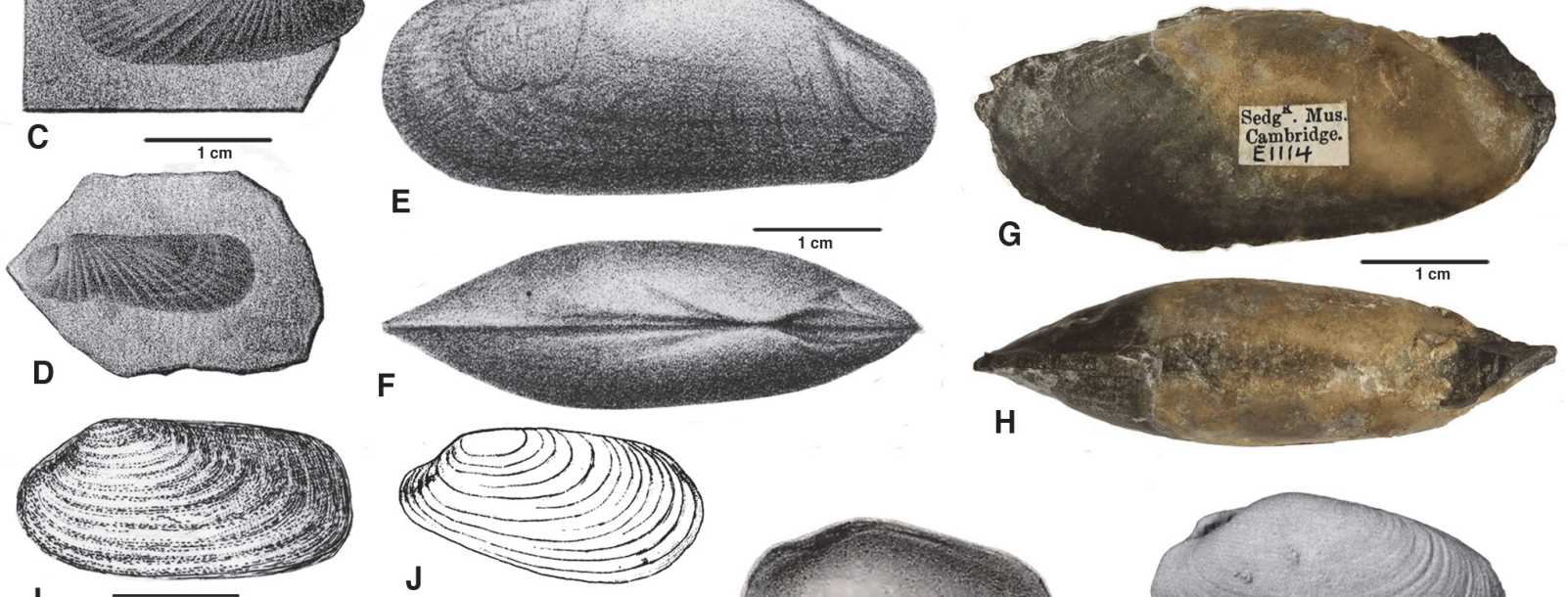

$\mathrm{F}$
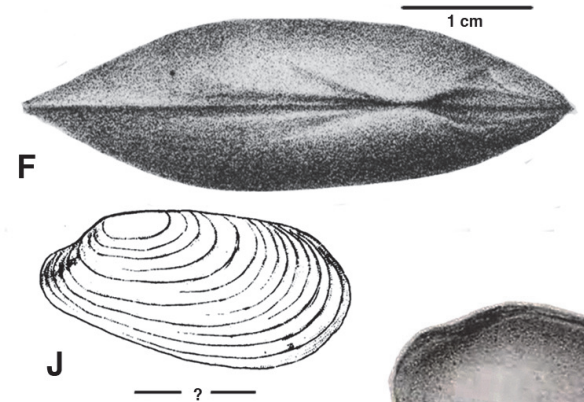

$1 \mathrm{~cm}$

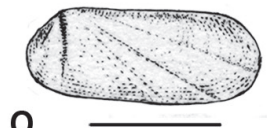

O

$1 \mathrm{~cm}$

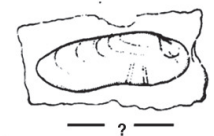

$\mathbf{P}$

$\mathbf{R}$

Q
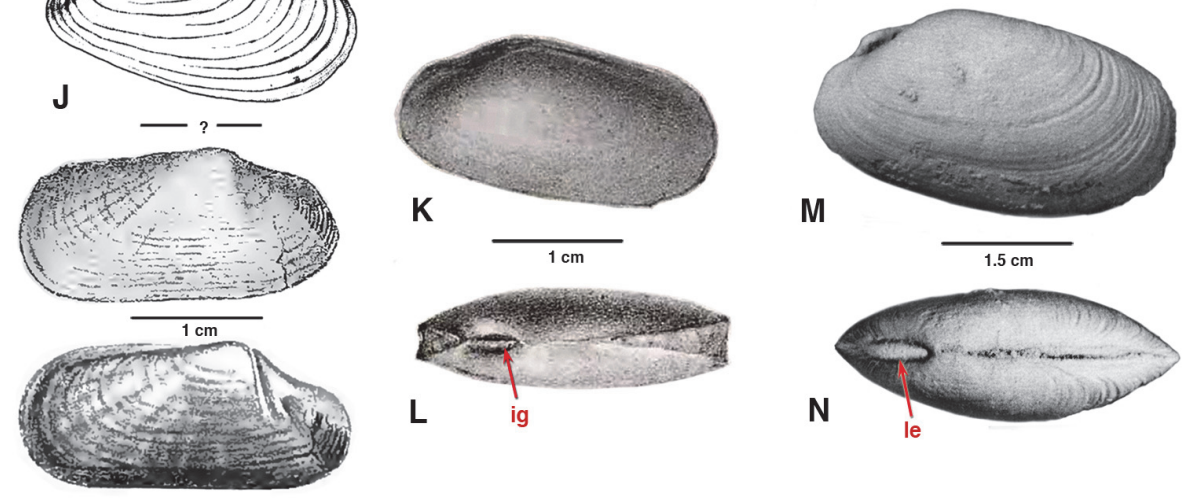

FIGURE 5 (caption on next page).

the interior of the umbo. The close-set nymphae shown on the brevidorsum appear to be external, recalling those of Acharax (Nacrosolemya) trapezoides (Meek, 1874) (see Beede and Rogers 1899, pl. 32, fig. 2b; Carter, 1990, fig. 17d), an interpretation that seems supported by M'Coy's own description (1855, p. 519$)$ : “...on its outer or posterior margin the slight thickening of the external cartilage support [= nymphae] is clearly seen, and the reflected gaping [= internymphal gap] edge of the lunette in some specimens..." Surprisingly, these features are not validated by M'Coy's actual topo- type (Sedgwick Museum, no. E1114), a natural cast with attached matrix (Figure 5G-H) on which his illustrations (evidently interpretive reconstructions) were based. In particular, the hinge morphology of the topotype is inconsistent with M'Coy's figure, providing few clues concerning the exact mode of ligament attachment. Yet, the posterior adductor is simple, and the elevated brevidorsal feature that M'Coy called a "lunette" (p. 519) appears consistent with external nymphae. It is worth noting here that Hind (1900, p. 444) 
regarded M'Coy's figures as "largely hypothetical, especially the view of the hinge-line and umbones."

Solemyids comparable to $S$. primaeva have been treated by several authors. De Verneuil's (1845, pl. 19, fig. 5) specimen of S. primaeva from the Lower Permian of Russia is fragmentary; only the anterior portion of the shell is preserved; the ligament-bearing posterior portion of shell is missing. Both M'Coy (1855 p. 520) and Hind (1900, p. 440) accepted Solemya puzosiana de Koninck, 1842, Carboniferous of Belgium (Figure 3B-E), as a synonym of $S$. primaeva. However, M'Coy (1855) separated the species into two varieties: $S$. primaeva of Phillips he informally called S. primaeva var. $\alpha$ whereas Solemya puzosiana de Koninck, 1842 (p. 60, pl. 5, fig. 2a, b; Carboniferous of Belgium) he formally named $S$. primaeva var. $\beta$. Similar shells, M'Coy noted, occur in the Lower Carboniferous dark limestone of Lowick and black beds of Derbyshire.

Zhang and Pojeta (1986, p. 670, fig. 5.4) reported Solemya (Janeia) primaeva (Phillips) from the Ceshui Formation (Lower Carboniferous of China). Their specimen resembles Hind's (1900) topotype and Portlock's hypotype (Figure 5B).
Janeia biarmica (de Verneuil, 1845). King's (1850, pl. 16, fig. 7) example of J. biarmica from the Upper Permian, Tunstall Hill, and Humbledon Quarry, is not a solemyid (Figure 5I). The umbos are too prominent, and the shell is marked by regular, broadly rounded comarginal ribs (radii lacking), and a subtruncate longiterminus. Rather, it is a probable pholadomyoid, i.e., Wilkingia elegans (King) (see Logan, 1967, p. 63). Richard Howse (1857a, p. 309), a colleague and collaborator of King's, called it a juvenile specimen of Allorisma elegans [= Wilkingia elegans], and Geinitz (1861, p. 57) agreed.

King (1850, p. 178) placed Solemya abnormis Howse, 1848 from the Upper Magnesian Limestone (Upper Permian), Tunstall and Silksworth, in synonymy with J. biarmica. Howse (1857a, p. 309) not only disagreed with King's conclusion but also professed reluctance in referring it to Solemya. His two figures of S. abnormis (Howse, 1857a, pl. 4, figs. 8,9$)$ are simple drawings. Although the ambiguous shell fragment in his figure 9 shows no distinguishing traits, the modioliform Silksworth shell shown in his figure 8 (Figure $5 \mathrm{~J}$ herein) compares with Stutchburia modioliformis (King) sensu Logan (1967, p. 50, pl. 8, fig. 8a-e) from the reef

FIGURE 5 (figure on previous page). Classic exemplars of Janeia King of past authors. A-H, Solemya primaeva Phillips, 1836. A, putative holotype (lost) of Phillips, 1836, pl. 5, fig. 6 (= type species of Janeia by original designation of King, 1850, p. 177), Lower Carboniferous of Lowick, Northumberland, England. B, composite mold, left valve; a large hypotype identified by Portlock (1843, p. 441) as S. primaeva Phillips (figure of Hind 1900, pl. 50, fig. 1), Carboniferous shales of Aghaloo Parish, Co. Tyrone, N. Ireland. C, composite mold, left valve of a topotype (Hind, 1900, pl. 50, fig. 5); same figure used by $\operatorname{Cox}(1969$, fig. B1.1a), Lower Carboniferous, Lowick, Northumberland. D, composite mold, right valve of a hypotype (Hind, 1900, pl. 50, fig. 6) (= type of Sanguinolites radiatus M'Coy, 1844, p. 50), Killymeal, Dungannon, Co. Tyrone. The simple buttresses and non-occluded posterior adductors in 5B-D are consistent with Acharax. E-F, Solemya primaeva Phillips as figured by M'Coy (1855), Lower Carboniferous, Lowick, Northumberland. E, left lateral view (M'Coy, 1855, pl. 3F, fig. 3). F, same specimen, dorsal view (M'Coy, 1855, pl. 3F, fig. 3a). G-H, actual specimen (Sedgwick Museum no. E1114) used by M'Coy as the basis for Figures 5E-F (photos by Matthew Riley). G, left lateral view. H, dorsal view. The details shown in M'Coy's figures appear to be largely hypothetical. I, Janeia biarmica (de Verneuil, 1845), figure of King, (1850, p. 178, pl. 16, fig. 7) [= Wilkingia elegans (King)], Upper Permian, Humbledon Quarry, Durham, England. J, Solemya abnormis Howse, 1848, p. 244; 1857a, p. 309, pl. 4, fig. 8; Upper Permian "Shell-Limestone", Silksworth, Durham; King (1850) accepted it as a synonym of J. biarmica; Logan (1967) called similar topotypic shells Stutchburia modioliformis (King). K-L, Solemya biarmica de Verneuil 1845, pl. 19, fig. 4a, 4b, Lower Permian, Nizhny, Novgorod Oblast, Russia; herein reassigned to Dystactella Hall and Whitfield. $\mathbf{K}$, holotype, an internal mold, right lateral view. L, dorsal view of same showing anterior and posterior gapes; the infilling of the internymphal gap (ig) is evidence of an external parivincular ligament. $\mathbf{M}-\mathbf{N}$, Dystactella subnasuta (Hall and Whitfield, 1872), Lower Devonian (Upper Helderberg), Louisville, Kentucky. M, right lateral view of articulated specimen (= "Specimen A", USNM 145650) of McAlester (1968, pl. 5, fig. 7). N, dorsal view of "Specimen A" of McAlester (1968, pl. 5, fig. 9) showing cylindrical external ligament (le) on the posterodorsum; the similarities to $S$. biarmica de Verneuil are conspicuous. O, Janeia phillipsiana King, 1848 (from King, 1850, p. 179, pl. 16, fig. 8); Howse (1857b, p. 9) called it a "mere fiction." P, Solemya normalis Howse, 1848 as figured by Howse (1857a, pl. 4, fig. 7); placed in synonymy with J. phillipsiana by King (1850, p. 179), Upper Permian, Humbledon Hill, Durham. Q, Solemya phillipsiana King, figure of Schauroth (1854, p. 553, pl. 21, fig. 5), lower Zechstein (Upper Permian), Bucha, Germany. R, same specimen reinterpreted by Geintiz (1861, p. 60, pl. 12, fig. 19) and placed by him in synonymy with S. biarmica. Note the marked differences in shell shape and detail; both the cleft formed by the buttress and adjacent adductor scar are missing in Schauroth's figure. 
facies, Middle Magnesian Limestone (Upper Permian), Tunstall Hill, Durham. Later, Howse (1858, p. 266 , pl. 11, figs. 8, 9) published the same Silksworth shell under the name of "Solemya biarmica?" (see Appendix).

De Verneuil's (1845, pl. 19, fig. 4a, b) original specimen of Solemya biarmica, herein assigned to the clinopisthin, Dystactella, is a smooth internal mold from the Lower Permian of Nizhny Novgorod Oblast (Russia) (see Figure 5K-L). Unlike Acharax and Solemya, the umbos are broader, more elevated and more subcentrally placed than in either of these genera, and the shell is expanded anteroventrally. Furthermore, the shell radii that often mark internal molds of both Solemya and Acharax are uncharacteristically absent. The thin cylindrical ridge along the brevidorsum is probably a sediment infilling of an internymphal gap associated with a strong external ligament. The characters and the shell profile of de Verneuil's figured type precisely match McAlester's (1968, pl. 5, figs. 3-11) and Pojeta's (1988, pl. 8, figs. 1-10) specimens of Dystactella subnasuta Hall and Whitfield, 1872 (type species of Dystactella) from the Silver Creek Limestone Member of the Sellersburg Limestone (Middle Devonian) of Clark County, Indiana. (compare Figure 5K-L with Figure 5M-N) Herein, de Verneuil's original figured type of Solemya biarmica is emended as Dystactella biarmica (de Verneuil, 1845) new combination (see Appendix).

A tiny specimen attributed to $S$. biarmica by Geinitz (1848, p. 8, pl. 3, fig. 34) from the Permian Kupferschiefer of Kamsdorf, Germany, is not instructive. However, a second example figured by Geinitz (1861, p. 60, pl. 12, fig. 18) superficially resembles de Verneuil's figured type (= Dystactella), but ligamental and other data are lacking. Logan's $(1967$, pl. 10, fig. 11, 12) figured specimens, hypotypes "A" and "B" respectively, from the Upper Permian Middle Magnesian Limestone, Durham, were described under the emended name, Janeia biarmica (de Verneuil, 1845). Hypotype "A", from Humbledon Hill, is an internal mold that generally agrees with de Verneuil's type. However, Logan's inferred profile of the incomplete hypotype " $\mathrm{B}$ " from Tunstall Hill is more like Acharax although the prosoponal radii characteristic of some (but not all) species of this genus are not evident. Unlike de Verneuil's figured type, hypotype "B" is far more inequiaxal with lower umbos. Significantly, it convincingly shows remains of paired external ligamental nymphae separated by a narrow oval cleft (internymphal gap), features associ- ated with both Acharax and Dystactella but not Solemya.

Janeia phillipsiana (King, 1848). King's figure (1850, pl. 16, fig. 8) shows an internal mold, extremely inequiaxial in form, with barely discernible umbo and beak. A few radial ribs are indistinctly shown along with a narrow furrow for a simple buttress extending vertically to the beak but lacking an adjoining groove for the diagnostic submarginal nymph of Solemya (see Figure 50). Significantly, in a scathing denunciation of King's work, Howse (1857b, p. 9) accused King of specimen theft, plagiarism, and deceit, calling King's Janeia phillipsiana a "mere fiction", and asserting that his published description and figure were inventions based on non-existent fossil material. Accordingly, King's (1850, p. 179) placement of Solemya normalis Howse, 1848 in synonymy with J. phillipsiana was also denounced by Howse (1857a, p. 309; 1857b, p. 9; 1858, p. 266).

Howse's (1857a, pl. 4, fig. 7; 1858, pl. 11, fig. 7 ) own illustration of $S$. normalis is a simple drawing of an elongated shell with low umbos marked by comarginal lineations with few radii and, apparently, an entire posterior adductor scar (see Figure $5 \mathrm{P})$. However, the shell is unusual in its slightly arcuate profile and broadly embayed ventral margin. In a footnote, Howse (1857a, p. 308; 1858, p. 265) admitted that anterior extremity of his drawing was not correctly represented. Thereby, placement within the Solemyidae cannot be fully confirmed. More recently, Logan (1967, p. 61) gave recognition to Janeia normalis (Howse) based on material from the Upper Permian Magnesian Limestone at Tunstall Hill. However, these are referable to Acharax inasmuch as Logan (p. 62) observed external ligamental nymphae in his hypotypes. Although prosoponal radii are either weak or lacking, the shell profiles (see Logan, 1967, pl. 10, figs. 13, 14) are intermediate between Solemya parallela Beede and Rogers, 1899, pl. 34, fig. 1 (= Acharax parallela (Beede and Rogers) emend. Bailey, 2011) and Acharax primaeva (i.e., S. primaeva sensu Hind, 1900, non Phillips, 1836).

From the lower Zechstein (Upper Permian) of Germany, Schauroth (1854, p. 553, pl. 21, fig. 5) described a specimen he hesitatingly referred to Solemya phillipsiana (King). His figure shows a relatively featureless internal mold with an anomalously thick shell remnant attached just above the "posterior" (breviventral) margin (Figure 5Q). The shape of the bivalve superficially agrees with other solemyins and is subtly marked by a few radial elements. Subsequently, Geinitz (1861, p. 60, pl. 12, 
fig. 19) refigured Schauroth's original specimen but assigned it to Solemya biarmica de Verneuil, although the similarities to that species are few. Interestingly, Geinitz's figure of the same specimen is startlingly different from Schauroth's. Although Geinitz's figure, like that of Schauroth, shows the same telltale shell remnant, the overall profile of the bivalve is noticeably altered (see Figure 5R). More significantly, the internal mold in Geinitz's figure is marked by a deep groove for an internal buttress flanked by an adductor scar. Surprisingly, these features are altogether missing in Schauroth's figure. If Geinitz's illustration is accurate, the septum-like buttress is simple but appears unusually deep and well defined but does not appear to directly border the adductor scar as expected. The adductor scar, though entire, is unusual in its more breviventral placement. Although the shell profile superficially recalls Acharax parallela (Beede and Rogers), the umbos are more prominent and less extreme in posterior placement, and strong comarginal lirae adventitiously mark the outer surface of the shell remnant. Because of the many disparities, taxonomic placement of this specimen is undetermined, and its location is unknown.

\section{A PERPLEXING LEGACY}

\section{Janeia Reinvented}

Despite King's own abandonment of Janeia and Howse's recriminations, subsequent authors found various problematic reasons for reinstating the name. Fielding Bradford Meek (in Meek and Worthen, 1870, p. 44) suggested reviving Janeia as a subgenus of Solemya for CarboniferousPermian shells similar to those of King (1850) but showing left-over-right overlap of the beaks. Meek speculated that King's failure to mention overlap in his original diagnosis of Janeia may have been due to an insufficiency in available material. In 1871, Meek (p. 66) described Solemya (Janeia) vetusta from the Corniferous Limestone (Devonian), Franklin Co., Ohio, and published a figure of it two years later (Meek, 1873, pl. 18, fig. 4). The distinctive shell (Figure 6A) shows the marked anteroventral expansion vector and prominent external ligament seen in the Clinopisthinae (i.e., Clinopistha and Dystactella). The similarities to Dystactella valvulus (Hall and Whitfield, 1872) from the Middle Devonian (Silver Creek Limestone Member, Sellersburg Limestone) of Indiana are fairly strong although Pojeta (1988, p. 217) rejected conspecificity (but compare with Pojeta, 1988, pl. 10, fig. 1). The low, subcentrally placed umbos, long, low-angled pos- terodorsal slope, weakly developed radii, and narrow posterior adductor bordered by a thin, weak buttress led Meek to compare it to Solemya biarmica de Verneuil, suggesting that King's abandoned genus, Janeia, should perhaps be reinstated and applied to solemyids with similar characters. James Hall (1885) followed Meek's precedent; his specimens of Solemya (Janeia) vetusta from the Middle Devonian Hamilton Group, near Louisville, Kentucky and Charlestown, Indiana, superficially agree with Meek's material (Figure 6B-D). Pojeta (1988, p. 217) placed all of Hall's figured specimens of Solemya (Janeia) vetusta in Dystactella valvulus. All of Hall's (1885) figured specimens show evidence of an external ligament in the form of narrow ridges (= external nymphae) along the brevidorsum. In particular, the uniquely scalloped radial elements in the prosopon (Figure $6 \mathrm{E})$ shown in one of Hall's $S$. (J.) vetusta exactly match those of $D$. valvulus illustrated by Pojeta (1988, pl. 10, fig. 1). Kindle's (1901) figures show similarities (Figure 6F-G). In addition, the paired external nymphae (Figure 6G, ne) are visibly separated by a narrow internymphal gap (Figure 6G, ig). All aforementioned biarmica-vetusta specimens of de Verneuil (1845), Meek (1873), Hall (1885), and Kindle (1901) are herein reassigned to Dystactella (see Appendix). Compare with figured specimens of McAlester (1968, pl. 5, figs. 1-11) and Pojeta (1988, pls. 6-10).

\section{Valve Inequality and Overlap}

In Dechaseaux's (1952, p. 264) treatment of solemyid genera, Janeia is given a range of Devonian-Permian and distinguished from Solemya only by being "légèrement inéquivalve." The roots of this problematic trait are traceable not only to Meek (p. 44 in Meek and Worthen, 1870; Meek, 1876, p. $127)$ but also to Beushausen (1895, p. 292). Both authors stressed the need for full reinstatement of Janeia in application to Paleozoic specimens similar to Solemya but showing a slight umbonal overlap (often left-over-right) of the opposing valves. However, Beushausen's (1895) emphasis on valve asymmetry in diagnosing Janeia must be seen within the larger context of his erroneous belief that, in general, valve inequality and overlap were natural characteristics of most Paleozoic bivalves.

Bailey (1983, figs. 34, 35, and p. 280) documented minor left-right inequalities in non-solemyoid protobranchs, for example, left-right valve height and depth inequalities in the Nuculidae (i.e., Nuculoidea deceptriformis Bailey, 1983) and leftright ligamental inequalities in the Malletiidae, i.e., 


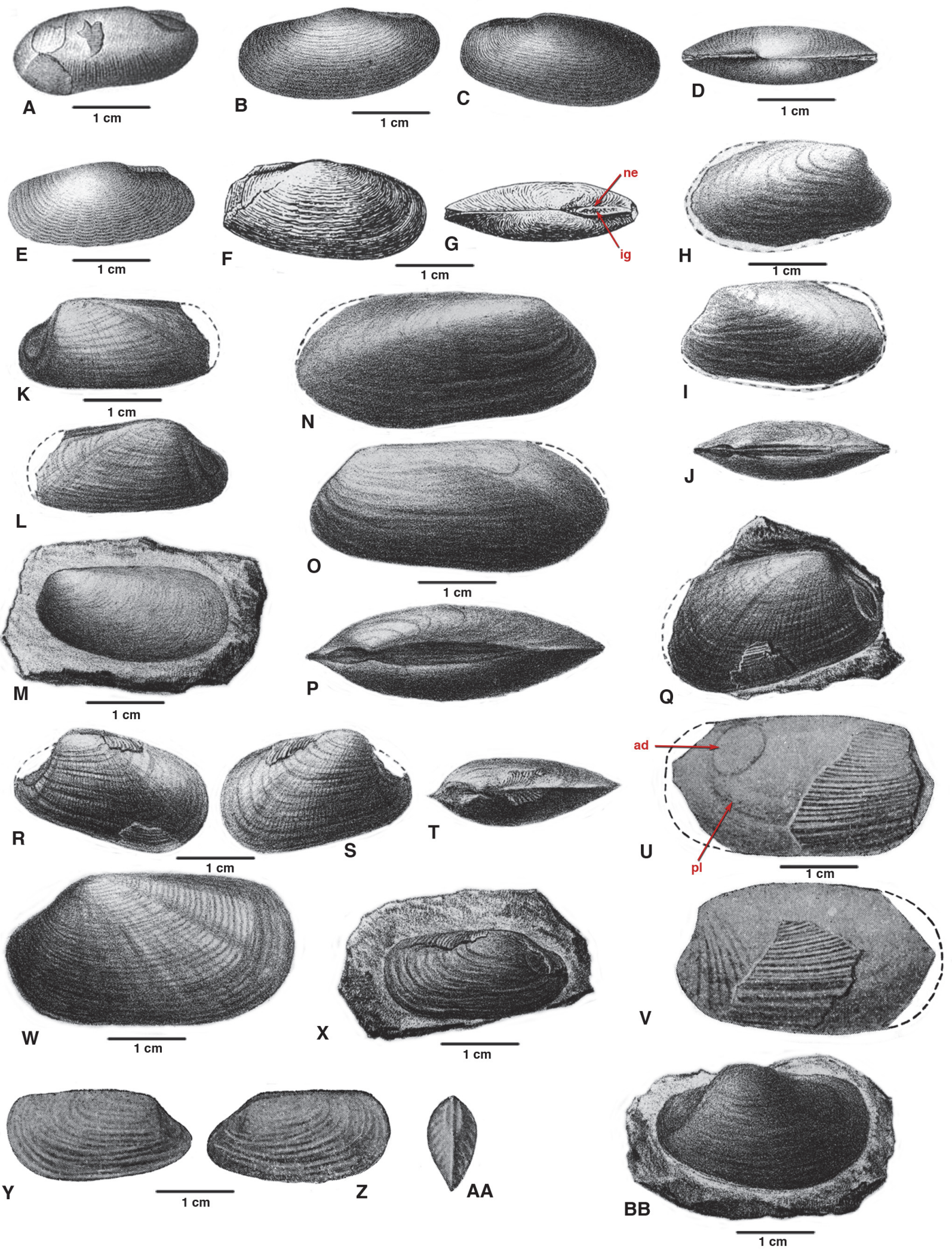

FIGURE 6 (caption on next page). 
Palaeoneilo filosa (Conrad, 1842). Among the Solemyidae, Bailey (2011) showed that valve overlap and inequality (including ligament lateralization) are common among the Solemyidae and by no means restricted to species referred to Janeia. Růžička and Řehoř (1978) likewise reported umbonal overlap in their Carboniferous genus, Janacekia, although it is a persistent character among the Solemyidae described as early as the Silurian (i.e., Janeia silurica Liljeldahl, 1984). Meek (1873) reported it in Devonian Clinopistha. It has also been observed in an undescribed species of Early Devonian Acharax (Bailey, 2011; Bailey and Prosh, 2016), as well as two common Pennsylvanian species, Acharax (Nacrosolemya) trapezoides (Meek, 1874) and Acharax radiata (Meek and Worthen, 1860) (see Carter, 1990; Bailey, 2011, text-fig. 4.2). In addition, it also occurs in extant Solemya, notably, Solemya (Zesolemya) parkinsoni Smith, 1874, and Solemya (Austrosolemya) australis Lamarck, 1818 (Carter, 1990; Carter et al., 1990; Bailey 2011).

Possible causes of the overlap summarized by Bailey (2011) include: 1) cracking and repair of the fragile umbonal region during growth (Waller, 1990); 2) reclining on one valve within the burrow as in extant Solemya (Petrasma) velum Say, 1822; and 3 ) the effects of post-mortem sedimentary compaction on the thin, pliable valves.

Based upon his incorrect assumptions regarding valve inequality and overlap, Beushausen (1895, p. 290) placed Paleozoic so-called "Solemya" of previous authors in Janeia. In addition, he expanded and shaped his understanding of Janeia to include both Dystactella and Clinopistha. As Beushausen admitted on page 294: "Eine generische Verschiedenheit von Clinopistha und Janeia kann ich jedenfalls nicht anerkennen." As exemplars of his broad vision of Janeia, he chose four species from the Devonian of the Rhineland previously placed by Goldfuss (1840) in Sanguinolaria Lamarck, 1799. Each of these is evaluated below:

Janeia? compressa (Goldfuss, 1840). Beushausen's placement of this species in Janeia was tentative. Neither his designated type (Sanguinolaria compressa Goldfuss, 1840 , p. 280 , pl. 159, fig. $16 \mathrm{a}-\mathrm{b}$ ) nor his figured specimen (Figure $6 \mathrm{H}-\mathrm{J}$ ) is a solemyid. Both are somewhat modioloid in form with a laterally compressed shell (height/total width $=1.73$ ). Alternatively, both favorably compare with published examples of Pleurophorella Girty, 1904, e.g., Pleurophorella transversa (de Koninck, 1842) (see Morris et al., 1991, fig. 41) from the Lower Carboniferous of Tournai, Belgium (see Appendix).

FIGURE 6 (figure on previous page). Classic exemplars of Janeia King of past authors. A-G, Solemya (Janeia) vetusta Meek, 1871 [= Dystactella Hall and Whitfield]. A, left lateral view, internal mold with partial shell (Meek, 1873, pl. 18, fig. 4), Devonian, Ohio. B-D, articulated specimen, Middle Devonian, Louisville, Kentucky. B, left lateral view (Hall, 1885, pl. 47, fig. 53). C, right lateral view (Hall, 1885, pl. 47, fig. 54). D, dorsal view, anterior to right (Hall, 1885, pl. 47, fig. 55). E, a left valve showing scalloped radii and cylindrical external ligament, Middle Devonian, Charlestown, Indiana (Hall, 1885, pl. 94, fig. 10). F-G, articulated specimen, Middle Devonian, Charlestown, Indiana. F, right lateral view (Kindle, 1901, pl. 16, fig. 1). G, dorsal view, posterior at right (Kindle, 1901, pl. 16, fig. 1a) showing external nymphae (ne) and internymphal gap (ig). H-J, Janeia? compressa (Goldfuss, 1840) of Beushausen (1895), an internal mold [= Pleurophorella? aff. transversa (de Koninck)], ?Middle Devonian, Daleiden, Germany. H, right lateral view (Beushausen, 1895, pl. 26, fig. 1a). I, left lateral view (Beushausen, 1895, pl. 26, fig. 1b). J, dorsal view showing lunule and escutcheon (Beushausen, 1895, pl. 26, fig. 1C). K-P, Janeia laevigata (Goldfuss, 1840). K-L, an internal mold [= ?Pleurophorella cf. tricostata (Portlock)], Middle Devonian, Gerolstein, Germany; note prosoponal radii and short buttress bordering deeply impressed anterior adductor scar. K, left lateral view (Beushausen, 1895, pl. 26, fig. 3a). L, right lateral view (Beushausen, 1895, pl. 26, fig. 3b). M, lateral view of type (Goldfuss, 1840, pl.159, fig. 14), gen. indet., Devonian, Eifel; also figured in Beushausen (1895, pl. 26, fig. 8) N-P, an articulated specimen [= Pleurophorella? sp.], Devonian, Daleiden. N, right lateral view (Beushausen, 1895, pl. 26, fig. 2a). O, left lateral view (Beushausen, 1895, pl. 26, fig. 2b). P, dorsal view (Beushausen, 1895, pl. 26, fig. 2c); note strong similarities to Figure 6J. Q-V, Janeia truncata (Goldfuss, 1840). Q, internal mold with attached shell fragments, left lateral view [= Clinopistha Meek and Worthen], Middle Devonian, Stringocephalus Limestone, Gerolstein (Beushausen, 1895, pl. 26, fig. 5). R-T, internal mold with attached shell fragments [= Clinopistha], Devonian, Eifel. R, right lateral view (Beushausen, 1895, pl. 26, fig. 4b). S, left lateral view (Beushausen, 1895, pl. 26, fig. 4a). T, dorsal view, anterior at right (Beushausen, 1895, pl. 26, fig. 4c). U-V, internal mold with partial shell [not a soleymid]; lateral views showing ciricular adductor scar (ad) and distinct pallial line (pl) (Beushausen, 1895, text-fig. 32, p. 297), Middle Devonian, Gerolstein. W-BB, Janeia phaseolina (Goldfuss, 1840). W, lateral view of type (Goldfuss, 1840, p. 279, pl. 159, fig. 15), gen. et sp. indet., Devonian, Eifel; also figured by Beushausen (1895, pl. 26, fig. 9). X, lateral view of an internal mold (Beushausen, 1895, pl. 26, fig. 6), Devonian, Eifel [= ?Edmondia de Koninck]. Y-AA, articulated specimen [= ?Edmondia], Gerolstein (Beushausen, 1895, text fig. 31, p. 296). Y, right lateral view. Z, left lateral view. AA, end view. BB, lateral view of an internal or composite mold, lower Middle Devonian, Gerolstein (Beushausen, 1895, pl. 26, fig. 7) [possible sanguinolitid; = ?Myofossa Waterhouse]. 
Although the hinge, ligament and internal morphology of Janeia? compressa are unknown, the dorsal views of both Goldfuss' shell and Figure $6 \mathrm{~J}$ are similar. Each is posteriorly elongate with a welldefined lunule and escutcheon.

Janeia laevigata (Goldfuss, 1840). Beushausen described neither the hinge nor internal characters. His first example (Figure 6K-L) favorably compares with Sanguinolites striatograunulatus Hind, 1900 (p. 393, pl. 42, figs. 6-22). Though superficially resembling a solemyid in profile and prosponal radii, it is posteriorly elongate. Like Acharax, it has an internal buttress, but here it is shorter and posteriorly borders a well-marked anterior adductor. Based on their restudy of Hind's syntypes from the Lower Carboniferous of the Isle of Man and Yorkshire, Morris, et al. (1991, p. 87, fig. 38c-h) judged $S$. striatogranulatus to be a likely synonym of Pleurophorella tricostata (Portlock, 1843). Beushausen's second example (Figure 6M), his designated type of Janeia laevigata, is a copy of Sanguinolaria laevigata Goldfuss, 1840, p. 279, pl. 159, fig. 14. However, because much of it is embedded in sedimentary matrix, the generic identity of the type is indeterminate. His third example (Figure 6N-P) compares in profile to the following: 1) ?Pleurophorella cuneata (Phillips,1836) (Morris et al., 1991, p. 88, fig. 42) from the Lower Carboniferous, Bolland, Yorkshire; 2) Pleurophorella sp. from the Upper Pennsylvanian of Texas (Morris et al., 1991, fig. 40), and 3) Pleurophorella? sp. from the Pennsylvanian of Brazil (Anelli et al., 2009, fig. 2H). The laterally compressed shell (dorsal view, Figure 6P), and well-marked lunule and escutcheon, are notably similar to Beushausen's Janeia? compressa (dorsal view, Figure 6J).

Janeia truncata (Goldfuss, 1840). Two of the figured specimens of $J$. truncata on Beushausen's (1895) plate 26 are solemyids (i.e., clinopisthins), probably Clinopistha Meek and Worthen (see Figure $6 \mathrm{Q}-\mathrm{T}$ ) although the ligament is not preserved. Beushausen (1895, p. 297) compared J. truncata to Janeia (Solemya) vetusta (= Dystactella valvulus sensu Pojeta, 1988, non Meek, 1871), whereas Hind (1900) compared it to Clinopistha. However, one of Beushausen's examples of alleged $J$. truncata is problematic (Figure $6 \mathrm{U}-\mathrm{V}$ ). The pallial line (pl) is far too distinct for a solemyid (see Cox, 1969, p. N241). In addition, the well-delimited circular profile of the "anterior" adductor scar (ad) suggests a discrete muscular unit, whereas among the Solemyidae it is typically a pyriform composite scar formed by the contiguous placement of the anterior adductor muscle and the visceral/pedal retractor and protractor muscle complex (Bailey, 2011, p. 12). Cox (1969, p. N242) considered the composite anterior scar to be a distinctive feature of the Solemyidae.

Janeia phaseolina (Goldfuss, 1840). The figured specimens of $J$. phaseolina on Beushausen's (1895) plate 26 appear to be a heterogeneous mix of bivalves none of which are solemyids (see Appendix). Goldfuss's type, Sanguinolaria phaseolina Goldfuss, 1840 (see Figure 6W) is generically indeterminate (possible edmondiid?), whereas two of Beushausen's shells (Figure 6X, Y-AA) appear to be edmondiids, possibly Edmondia de Koninck, 1841 (see remarks of Hind, 1900, p. 297). A third specimen (Figure 6BB), is substantially different from the others. Although the hinge and ligamental attachment are not shown, the short, sulcate shell with tumid umbo recalls certain sanguinolitids, possibly Myofossa Waterhouse, 1969 (see Morris et al. 1991, p. 61, fig. 8).

In his celebrated monograph on Carboniferous bivalves of Great Britain and Ireland, Hind (1900) was critical of Beushausen's (1895) reinstatement and emendation of Janeia, suggesting that the dorsal overlap emphasized by Beushausen was largely accidental due to simple displacement of the valves owing to the lack of dentition, noting similar displacement in unrelated bivalve taxa. Moreover, he observed, the left-over-right displacement, though common, was inconsistent. In many cases the displacement was the reverse, and in still other cases displacement was lacking altogether. As a result, Hind reassigned King's type species, Janeia primaeva once again to Solemya. Although Hind did not discuss the ligament, the internal molds figured specimens in his plate 50 (Solemya primaeva Phillips, Solemya excisa de Koninck, 1885, and Solemya costellata M'Coy, 1844), the simple buttresses and entire posterior adductors favor reassignment to Acharax.

\section{The Ligament Puzzle}

As noted above, King (1850, p. 247) in his final analysis judged Janeia to be identical with Solemya. As a result, the placement of the ligament of Janeia was presumed to be internal, attached at chondrophores. However, in order to explain the external ligament preserved on some fossil specimens, de Ryckholt (1854, p. 49) surmised that, although the ligament of Solemya was attached internally, it nonetheless protruded to the outside. Of particular interest here is Beushausen's (1895, p. 290) observation of a small opening ("schmale Oeffnung") bordered on each side by 
"verdickten, schrägen Ligamentstützen" (= external nymphae) in published figures of, for example, Solemya puzosiana de Koninck (1842, pl. 5, fig. $2 a, 2 b ; 1885$, pl. 23, fig. 34) (i.e., Figure 3B-E herein). Like de Ryckholt before him, Beushausen incorrectly hypothesized the opening (= internymphal gap) to be a dorsal orifice through which King's alleged internal ligament was permitted to protrude to the exterior. Hind (1900, p. 442) held a similar view. However, Beushausen accorded no particular taxonomic significance to this feature, noting that the opening was seen in some specimens of Janeia but not others. Among the Solemyinae, it must be again emphasized here that the presence of the internymphal gap argues for an external ligament as in Acharax. Generic placement in Solemya is thereby excluded because, as previously noted, the ligament is secondarily enclosed by an outer prismatic layer.

Although Quenstedt (1930), a follower of Beushausen, attempted to describe and illustrate the ligament support structures of Janeia, his conclusions are unsupported. At the outset, it must be emphasized that Quenstedt, like his antecedents, began with the erroneous assumption that the ligament of Janeia, like that of Solemya, was internal. His ink drawings (Quenstedt, 1930, pl. 1, figs. 3-4) compared transverse sections through the beaks, one in extant Solemya (Zesolemya) parkinsoni Smith, 1874, and the other in a specimen Quenstedt identified as Janeia truncata (Goldfuss, 1840), from the Middle Devonian, Gerolstein, Germany. The transverse section of the internal nymph in the former appears, as expected, as a simple, recumbent, distally thickened, sublamellar plate, whereas the transverse section of the latter unexpectedly shows a robust, L-shaped ossicle (Figure 7A) alleged by Quenstedt to be a chondrophore for attachment of an internal ligament, a conclusion derided by Hajkr, et al. (1978, p. 11) as unnatural (i.e., "unnatürlich"). Although the strong angle and upright prolongation of the ossicle are generally consistent with an external nymph, the structure is so unnaturally thick and large that neither it nor the associated ligament could believably be accommodated internally if a similarly structured opposing valve (Figure 7B) were fitted into place (Figure 7C). However, if an internymphal gap is introduced between the ossicles (Figure 7D), a reasonable configuration results. Thus, the problematic ossicles take on the form and placement of paired nymphae. By implication, the restored ligament was probably external.

A second problem in Quenstedt's (1930) study is his inappropriate choice of Janeia truncata as a basis for comparison with Solemya. As noted

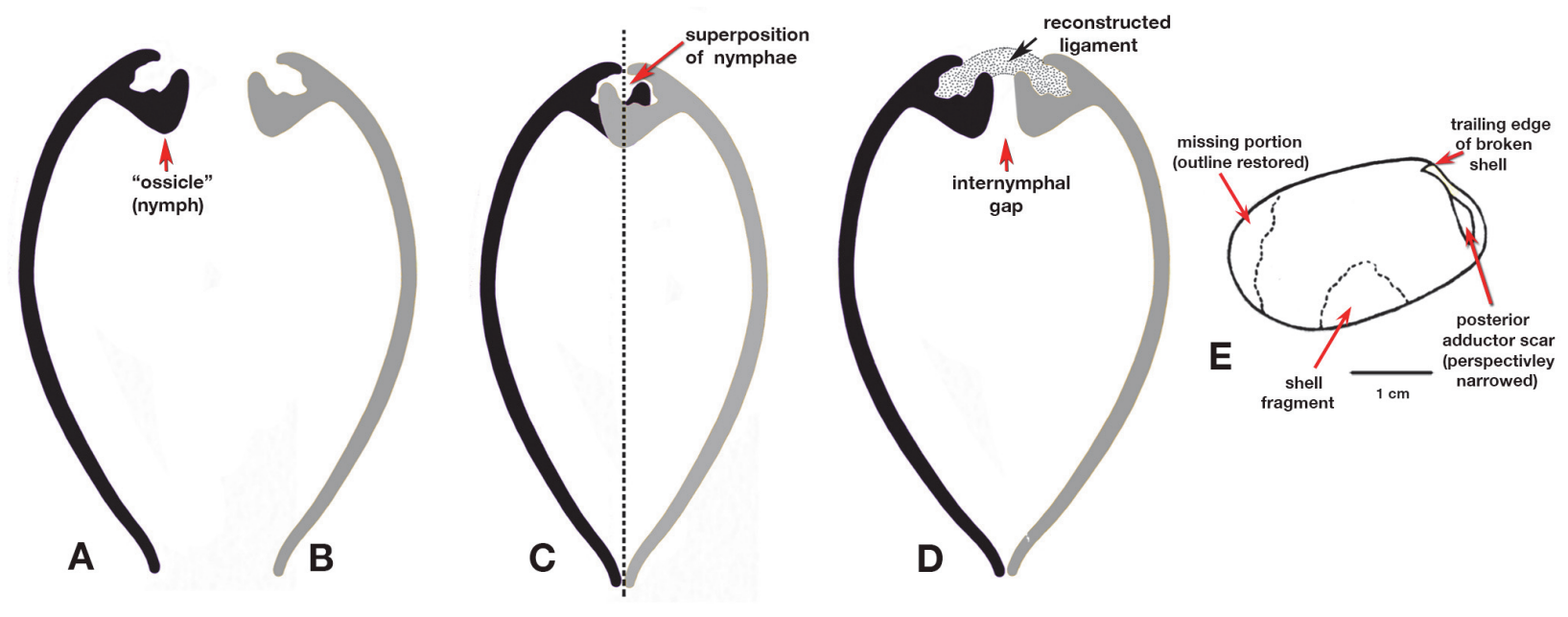

FIGURE 7. Interpretations of a transverse section through the beak of Janeia truncata, Middle Devonian of Gerolstein as figured by Quenstedt (1930, pl. 1, fig. 4) and reproduced in the Treatise by Cox (1969, N242, fig. B1,1b). A, Quenstedt's original ink sketch, a left valve, showing nymph-like ossicle (arrow) alleged to be a chondrophore for attachment of an internal ligament. B, inferred transverse section of right valve. C, incompatibility of right and left valves when fitted together with closed dorsal margins. As shown, the ossicle and its inferred counterpart irreconcilably overlap (arrow). D, a workable solution achieved by addition of an internymphal gap (arrow) separating the valves posterodorsally. By inference, the ossicles functioned as nymphae supporting an external ligament (stippled pattern, here reconstructed). E, Quenstedt's (1930, pl. 1, fig. 5) diagrammatic reconstruction of Janeia truncata based on the internal mold of a left valve figured by Beushausen (1895, pl. 26, fig. 5). For clarification, arrows and explanatory labels are added here. 
above, J. truncata is a clinopisthin, probably Clinopistha, a genus known to have strong external ligaments and nymphae (McAlester, 1968; Pojeta, 1988). Quenstedt's drawing of J. truncata (Figure $7 \mathrm{E}$ ) is a reconstructed outline of the left valve of an anteriorly incomplete internal mold earlier figured by Beushausen (1895, pl. 26, fig. 5). The missing portion of the specimen was restored differently by the two authors. Judging the anterior margin to be relatively short, Beushausen's reconstruction closely resembles Clinopistha, whereas Quenstedt's reconstruction shows anterior elongation comparable to Dystactella. In either case, the anteroventral growth vector (sensu Pojeta, 1988) is consistent with both Dystactella and Clinopistha but dissimilar to either Acharax or Solemya.

The diagrammatic markings along the posterior margin of Quenstedt's reconstruction were explained by Quenstedt in the explanation of his plate 1: 1) the narrow form and triangular outline of the posterior adductor is the result of perspective; 2 ) the vertical line running dorsally along the anterior margin of the posterior adductor represents the internal curvature of the umbo; 3 ) the sharp angle and short connecting line directly behind the beak corresponds to the trailing edge of the broken shell remnant and is indicative of the umbonal thickness of the shell (see Figure 7E).

\section{The Treatise and Beyond}

In Part N of the Treatise, Cox (1969, p. N242N243) accepted Janeia as a legitimate Paleozoic subgenus of Solemya. His diagnosis (p. N243) of $S$. (Janeia) reads as follows: "Resembling S. (Solemya) in external features and in presence of internal chondrophore; with internal ridge [= buttress] originating at anterior end of chondrophore and diverging from it at acute angle, passing below posterior adductor scar. Dev.-Perm., cosmopolitan." Unlike previous authors, Cox mentioned neither valve inequality nor umbonal overlap in his diagnosis. As exemplars, Cox chose a topotype of Solemya primaeva Phillips of Hind (1900) (see Figure $5 \mathrm{C}$ ) and the transverse section of Janeia truncata (Goldfuss) of Quentstedt (1930) (see Figure 7A). Cox's conclusions are rejected here for three reasons:

1. As noted by Logan (1967), Pojeta (1988), Bailey (2011) and herein, there is no evidence as alleged that the ligament was internally placed either in the type species or, indeed, any of the other species of Janeia proposed by King (1850) or subsequent authors. Cox's conclusion was apparently based on the L- shaped "chondrophore" in Janeia truncata figured by Quenstedt (Figure 7A). As shown above, J. truncata is a clinopisthin (probably Clinopistha). The L-shaped structures are nymphae supporting an external ligament.

2. Although the figured topotype $S$. primaeva used by Cox is a solemyin, the simple buttress and entire posterior adductor are consistent with Acharax but not Solemya. Previously, Bailey (2011, p. 30) argued that S. primaeva (and its possible variant, S. parallela Beede and Rogers, 1899) should be placed in Acharax (see Appendix).

3. Cox's conclusion that the internal "ridge" (= buttress) originates at the anterior end of the "chondrophore" and diverges from it at an acute angle was questioned by Dickins (1999) and is unsupported by the many published internal molds attributed to Janeia. Whereas it is true that the anterior end of the "chondrophore" (i.e., submarginal nymph) joins the buttress in modern Solemya, the two structures show no such connection in published specimens attributed to Janeia. Instead, the buttress in the topotypes is simple, continuing, as in Acharax, without connection or interruption along its entire length.

In a notable departure from the Treatise diagnosis, Liljedahl's (1984b, p. 27) reinterpretation of Janeia represents a revival of the criteria of valve inequality and overlap formerly advocated by Meek (1876), Beushausen (1895), and Dechaseaux (1952). His species, Janeia silurica Liljedahl, 1984a (Silurian of Mölbos, Gotland), is herein placed in the Clinopisthinae. As shown in his photographs (Liljedahl, 1984a, fig. 14A-J; 1984b, textfig. 1.1-1.6), the primary ligament (parivincular, opisthodetic) was attached at strong external nymphae. The parivincular primary ligament, internal features, and anteroventrally extended shell profile all support Pojeta's (1988, p. 217) contention that J. silurica should be reassigned to Dystactella. However, the left-over-right umbonal overlap in $J$. silurica is associated with a minor subumbonal ossicle (Liljedahl, 1984b, fig. 14H, 14I) present only in the right valve. The significance of this unique feature, which has elsewhere not been reported in Dystactella, was discussed by Bailey (2011).

Other studies accepting Janeia as a valid genus include Zhang (1977), Kłapciński and Karwowski (1978), Bernard (1980), Muromtseva (1981), Muromtseva and Guskov (1984), and Zhang and Pojeta (1986) (see Appendix). Like Cox (1969) before them, these studies either incorrectly 
accepted the ligament of Janeia as internal or do not mention the ligament at all. Bernard (1980, p. 21) regarded Janeia as a Permian subgenus of Solemya marked by prominent umbos at the posterior $1 / 4$ of the shell. Treating Janeia as a separate genus with a range of Silurian-Triassic, Nevesskaja, et al. (2013, p. 90) placed diagnostic emphasis on valve overlap.

\section{JANEIA VERSUS JANACEKIA}

There is a significant complication to the Janeia story. Rưžička and Řehor (1978) were critical of King's (1850) withdrawal of the name Janeia in favor of Solemya, arguing that King had failed to provide objective evidence that Janeia was related to Solemya. Determination of the anterior and posterior ends of the shell, placement of the ligament, and organization of the internal anatomy, they asserted, were King's personal opinions. Yet, because King's original diagnosis of Janeia is both ambiguous and subjective, they were also critical of subsequent authors who adopted the name. Curiously, however, Růžička and Rehor (1978) agreed with King's erroneous opinion that the long end of the shell is posterior. In their study of an assemblage of Janeia-like shells from the Carboniferous of the Czech Republic, Růžička and Rehor (1978) concluded that the ligament was external, rather than internal, as King (1850) and subsequent authors had alleged. By comparing their shells to those of extant Solemya togata, Poli 1795, they also affirmed that King (1850) was wrong in asserting that the ligament of Janeia, like that of Solemya, was internal. Unfortunately, the authors did not compare their material with extant examples of Acharax, comparing them instead to the solecurtid genus Tagelus Gray, 1847, which they selected as an archetype. Because their interpretations agreed neither with Solemya nor Janeia sensu King, they proposed a new genus, Janacekia Růžička and Řehoř, 1978, herein accepted as a junior synonym of Acharax. Thus, there is neither justification for recognition of Růžička and Řehoř's family Janacekiidae nor any basis for regarding it as synonym of the Solemyinae as opposed to the Acharachinae (contra Bieler, et al., 2010, p. 115).

Both Acharax and Janacekia share the same shell profile, the same thick periostracum marked by radial ribs and lirae, and the same primary ligament (external, parivincular, opisthodetic). Significantly, the ligament of Janacekia as originally described by the authors is ironically in agreement with Acharax but not Solemya: "Ligament ist ein äußeres, kurz und opisthodet." (Růžička and
Řehoř, 1978, p. 37). However, because their understanding of anterior and posterior is reversed, the term "opisthodet" was incorrectly applied. Thus, this portion of their description becomes essentially correct but for the wrong reason.

Of critical importance in diagnosing Janacekia is a unique feature Růžička and Rehor termed the "pseudolunula", consisting of paired external lamellae located on the brevidorsm. Having observed an equivalent feature in "Solemya" radiata Meek and Worthen, 1866 (Pennsylvanian of Illinois), they suggested that "S." radiata would more reasonably placed in Janackeia rather than Solemya. However, based on examples with well-preserved ligaments from the Mazon Creek Lagerstätte (Pennsylvanian of Illinois), Bailey (2011) transferred "S." radiata to Acharax. Visual comparison of the brevidorsum of Janacekia (e.g., fig. 64 of Růžička and Řehoř, 1978) with that of Acharax (e.g., pl. 2, fig. 2 of Pojeta, 1988) demonstrates that the "pseudolunula" and external nymphae are synonymous.

Janacekia and Acharax show additional similarities that further secure their identity. As shown in figure 61 of Růžička and Rehoř (1978), the buttress in Janacekia, as in Acharax, is simple, extending dorsally from the anterior limit of the posterior adductor scar to the underside of the umbo without any suggestion of attachment to nymphae, and the posterior adductor muscle shows no indication of dorsal occlusion.

Although the analysis of Janacekia by Růžička and Řehor (1978) is comprehensive, it contains numerous errors and internal contradictions. For example, in their extensive biometric section (p. 18-27) the anteriorly elongate shell orientation is understood correctly, whereas, in the systematic section, the incorrect orientation (posteriorly elongate) is applied beginning on their page 37: "Der Vorderteil der Schalen ist kurz, enger als die Hinterzeite. Die hintere Teil ist stets länger als die Vordere." In addition, the authors provided a detailed reconstruction (their fig. 65) of the foot and pedal accessory musculature (pedal protractor, retractors, and elevators) placed at the short end of the shell, which they regarded incorrectly as the anterior.

Interpretative errors notwithstanding, the deltoid outline of the distinctive external, convexupward ligament of Acharax is documented in those authors' photos of Janacekia herberti (pl. 1, fig. 2, showing collapsed ligament with nymph termini), and Janacekia leosi (pl. 7, fig. 9). Moreover, deltoid traces (or possible traces) of the external 
ligament of Janacekia herberti and Janacekia leosi seem evident in several of their other photos (pl. 3 , fig. 12; pl. 8, fig. 9; pl. 11, fig. 4; and especially both pl. 7, fig. 9 and pl. 14, fig. 6). Traces of the anterior ligamental extension like Acharax radiata (Meek and Worthen, 1860) as figured by Bailey (2011, pl. $3,4)$ are evident in their pl. 6 , fig. 8 . The type species, Janacekia herberti from the Carboniferous (Namurian) Ostrava Schichtengruppe, Upper Silesian Coal Basin, Czech Republic, is so remarkably similar to Acharax radiata (Meek and Worthen) from the Mazon Creek Lagerstätte that, aside from differences in the relative relief of the radial ribs, the two are nearly indistinguishable. For example, compare Růžička and Řehoř (1978, pl. 7, fig. 9) with Bailey (2011, pl. 3, figs. 1-9; pl. 4, figs. 1-7). Interestingly, Rủžička and Řehoř listed numerous specimens referred by various authors to Solemya primaeva Phillips (= type species of Janeia King, 1850 ) as synonyms of both Janacekia herberti and Janacekia leosi. However, as noted above and by both Bailey $(2011,2016)$ and Logan (1967), S. primaeva is a probable Acharax.

In addition to $J$. herberti, three additional species of Janacekia (i.e., J. leosi, J. mariae, and J. talboti) were described by Růžička and Řehor (1978) (see Appendix). However, the apparent differences in shell profile and prosopon, which both seem fairly minor, are possibly due to variable taphonomic effects on the thin shells and compliant periostracum.

\section{CONCLUSIONS}

Character state analysis of the primary ligament and its support structures argues that Acharax and Solemya are monophyletic, a conclusion now in harmony with 18S rRNA and DNA studies (Taylor et al., 2008; Sharma et al., 2013). Thus, classification systems placing the two genera in separate families or superfamilies are not supported; Pojeta's (1966) placement of the two genera together in a single family and subfamily (Solemyidae: Solemyinae) is preferred.

Within the Solemyidae the external ligament and nymphae of Acharax, Clinopistha, Dystactella, and Psiloconcha are shared primitive (symplesiomorphic) characters, whereas the unique submarginal ligament and nymphae of Solemya are shown to be derived (autapomorphic) characters.

The submarginal nymphae of Solemya arose through depression of the external nymphae of Acharax ancestors followed by secondary overgrowth of a thin outer shelly layer, thus covering the ligament as well as its supporting nymphae and the internymphal gap separating them. Previously, submarginal nymphae in Solemya have been unsuitably termed "chondrophores", thus obscuring their homological relation to external nymphae of Acharax.

The adjusted ranges of Acharax and Solemya are: Lower Devonian-Holocene for Acharax; and Mesozoic (possibly Jurassic)-Holocene for Solemya.

Where ligaments are not preserved, fossil Acharax and Solemya are distinguishable from internal molds. New terms representing these characters are introduced: An internymphal gap, evident in Acharax, is absent in Solemya; a simple buttress, evident in Acharax, is compound in Solemya; an entire posterior adductor scar, evident in Acharax, is occluded in Solemya.

Misconceptions relating to King's (1850) Paleozoic genus Janeia have been instrumental in obscuring the monophyletic connections between Acharax and Solemya. Especially significant is the erroneous belief that Janeia, like Solemya, possessed an internal ligament - incorrectly presumed to represent a primitive (plesiomorphic) condition.

King's (1850) material basis for Janeia is critically reviewed. Although the figured type of J. primaeva (Phillips, 1836) (= King's selection as type species) is lost, topotypes have an external primary ligament and should be placed in Acharax. The remaining designated species of King (1850) are J. biarmica (de Verneuil, 1845) and J. phillipsiana (King, 1848). King's example of $J$. biarmica is a misidentified Wilkingia elegans (King, 1850), whereas de Verneuil's (1845) figured type designated Solemya biarmica is a clinopisthin, probably Dystactella. Janeia phillipsiana of King is an alleged fiction based on non-existent fossils.

In this study, Paleozoic solemyids previously placed in Janeia have been found to be mainly assignable either to Acharax, Dystactella, or Clinopistha. Other alleged Janeia (misidentifications) are not solemyids (see Appendix).

Based on King's (1850) erroneous assertions, subsequent authors were persuaded that Paleozoic solemyids possessed an internal ligament. De Ryckholt (1854), Beushausen (1895), and Hind (1900) misinterpreted the internymphal gap as an orifice (or slit) through which a presumed internal ligament was permitted to emerge to the outside. The small ossicle shown in Quenstedt's (1930) transverse section of $\mathrm{J}$. truncata, is reinterpreted herein as an external nymph rather than an internal chondrophore as he had originally supposed. Unfortunately, Quenstedt's misinterpretation cou- 
pled with King's erroneous conclusions formed the principal basis for acceptance of Janeia as a valid subgenus by Cox (1969) in the Treatise, Part N.

Janacekia is a problematic genus originally proposed by Růžička and Řehoř (1978) as a rejection of Janeia based on its inherent ambiguity and confusing history. Present analysis shows their interpretation of the shell orientation and ligamental structure to be incorrect. Janacekia is herein accepted as a junior synonym of Acharax.

\section{ACKNOWLEDGEMENTS}

I am grateful to M. Taviani, L. Angeletti, and A. Ceregato for use of the photo shown in Figure $3 \mathrm{~A}$ and to M. Riley, Sedgwick Museum, Cambridge, for the use of the two photos shown in Figure 5G$\mathrm{H}$. I thank the Geological Society of America for permission to use A.L. McAlester's photos shown in Figure 5K-M. My gratitude is likewise extended to R.E. Johnson for his assistance in the final preparation of the figures and to P.A. Johnston, A. Beu, R.L. Peck, T.A. Hegna, and two anonymous reviewers for their helpful comments on early drafts of the manuscript. My appreciation is also extended to L. Liljedahl and M. Hyžný for helpful communications. 


\section{APPENDIX}

\section{PALEOZOIC SOLEMYIDAE - REVIEW AND REVISION OF SELECTED TAXA}

The following treatise is a preliminary assessment and taxonomic review of Paleozoic bivalves misclassified either as Janeia, Janacekia, or Solemya (including nomina vana variants, Solenomya or Solenimya) based in part on the unsubstantiated assumption that among Paleozoic examples the primary ligament was set in internal chondrophores. Emphasis here is mostly on generic level evaluation and revision. Within synonymies, descriptive annotations and provenance are provided for most listings. The format in part follows recommendations of Matthews (1973) and Bengtson (1988). Publication dates given by de Ryckholt for various portions of his Mélanges Paléontologiques are revised based on Rosenberg and Petit (1987).

Abbreviations. Diagnostic character states observed: Bts = simple buttress; $\mathrm{Dp}=$ ligamental demipad; IG = internymphal gap; Le = ligament visibly external; $\mathrm{Ne}=$ nymphae external; $\mathrm{PAe}=$ posterior adductor entire; $\mathrm{PP}=$ traces of periostracal 'awning'. Prosopon: $\mathrm{Pc}=$ comarginal lirae/rugae; $\mathrm{PcO}=$ comarginal elements lacking; $\mathrm{PrO}=$ radii absent or not observed; Pr1f = fine, closely spaced radii; $\operatorname{Pr} 1$ = radii weak or obsolescent; Pr2 = radii marked; $\mathrm{Pr} 3=$ radii strongly marked; $\operatorname{Prs}=$ radii with scalloped pattern.

\section{SYSTEMATIC PALEONTOLOGY}

\author{
Class BIVALVIA Linnaeus, 1758 \\ Subclass PROTOBRANCHIA Pelseneer, 1889 \\ Superorder NUCULIFORMII Dall, 1889 \\ Order SOLEMYOIDA Dall, 1889 \\ Superfamily SOLEMYOIDEA Gray, 1840 \\ Family SOLEMYIDAE Gray, 1840 \\ Subfamily SOLEMYINAE Gray, 1840 \\ Genus ACHARAX DALL, 1908 \\ [= Janacekia Růžička and Řehoř, 1978]
}

Type species. By original designation, Acharax johnsoni (Dall, 1891), Holocene, NE Pacific.

Acharax primaeva (Phillips, 1836)

Remarks. Lost holotype of Phillips (1836) was imperfectly illustrated and diagnosed. Useful if Hind's (1900, in part, pl. 50, figs. 4, 5) topotypes are given priority (e.g., Cox, 1969). If so, Solemya puzosiana de Koninck, 1842 is a probable synonym. Hind (1900, p. 441) compared it with $S$. costellata and $S$. excisa but with stronger radial ribs.

? 1836 Solemya primaeva Phillips, p. 209, p. 247, pl. 5, fig. 6 [Pr3?, PAe?; nom. dub.; figure and diagnosis insufficient; holotype lost]; Lower Carbonferous, Lowick, Northumberland, England.

1842 Solemya puzosiana de Koninck, p. 60, pl. 5, fig. 2a, b [Pr3, Ne?, IG; = A. cf. primaeva, i.e., similar to Hind's (1900) topotypes and Portock's (1836) hypotype of S. primaeva]; Lower Carboniferous, (Tournaisian), Belgium.

1843 Solemya primaeva Phillips; Portlock, p. 441 [no figure; later figured by Hind (1900)]; Carboniferous, Aghaloo, Co. Tyrone, N. Ireland.

1844 Sanguinolites radiatus M'Coy, 1844, p. 50, pl. 13, fig. 4 [Pr3; synonym of Hind (1900, p. 438)]; Carboniferous, Killymeal, Dungannon, Co. Tyrone, N. Ireland.

? 1845 Solemya primaeva Phillips; de Verneuil, $p$. 295, pl. 19, fig. 5 [Pr2; gen. et sp. indet.; partial valve; hinge unknown]; Lower Carboniferous, Tarusa, Oka River, Russia.

? 1849 Solemya primaeva Phillips; Brown, p. 230, pl. 93, fig. 10 [Pr3?; stylized drawing after Phillips, 1836, pl. 5, fig. 6]; Lower Carboniferous limestone, Heiton and Lowick, Northumberland, England, and Co. Fermanagh, N. Ireland.

1850 Janeia primaeva (Phillips); King, p. 177 [no figure].

1850 Solemya primaeva Phillips; King, p. 246-247 [no figure].

? 1855 Solenimya? primaeva Phillips; M'Coy (?M'Coy), p. 519, pl. 3F, fig. 3, 3a [hypothetical reconstruction]; Lower Carboniferous limestone, Lowick, Northumberland, England.

1855 Solenimya primaeva Phillips var. $\beta$ puzosiana M'Coy, p. 520 [no figure]; Carboniferous, Derbyshire, and Northumberland, England

[Accepted by M'Coy (1855) as a variety of $S$. primaeva].

non 1859 Solenomya primaeva Phillips; Eichwald, [plates pub. 1859, text pub. 1860]; p. 5, pl. 39, fig.10a-b (1859) [Pr2; highly elongated shell with aberrant (upwardly curving) longiterminus; gen. et. sp. indet.; possibly not a solemyid]; p. 1040-1041 (1860); Carboniferous limestone, Tarusa and Peredki, Novgorod Oblast, Russia.

p 1885 Solemya puzosiana de Koninck; de Koninck, p. 120, pl. 23, fig. 41 [Pr3, Ne?]; fig. 29? [Pc, PrO]; figs. 33?, 34? [Pr2, Ne, IG]; [possibly 
composed of more than one species; see Bailey, 2011, p. 30]; fig. 41 [= A. cf. primaeva]; Lower Carboniferous (Tournaisian), Belgium.

1896 Solemya primaeva Phillips; Hind, p. 6, 27, 53

1900 Solenomya primaeva Phillips; Hind, pl. 50, fig. 1 (not fig. 2 as stated by Hind in error on p. 440) [Pr3, Bts, PAe; Portlock's (1836) unfigured hypotype; compares with topotypes but much larger and anteriorly more expanded]; Carboniferous, Aghaloo, Co. Tyrone, N. Ireland.

?1900 Solenomya primaeva Phillips; Hind, pl. 50, fig. 2? [Pr3; provenance?], pl. 50, fig. 3? [Pr3; valves shorter and dissimilar in profile to Hind's topotypes; = A. cf. costellata?]; Carboniferous limestone series, Ardross, Fife, Scotland.

p 1900 Solenomya primaeva Phillips; Hind, p. 438, pl. 50, figs. 4, 5 [topotypes, herein given priority; Pr3, Bts, PAe, IG]; Lower Carboniferous limestone, Lowick, Northumberland, England; non pl. 50, fig. 2 [Pr3; provenance?]; non pl. 50, fig. 3 [a hypotype, Pr3; shorter, more ovoid in profile], Carboniferous limestone series, Ardross, Fife, Scotland.

1900 Solenomya primaeva Phillips; Hind, pl. 50, fig. 6 [Pr3, Bts, PAe?; copy of M'Coy's1844 hypotype of Sanguinolites radiatus; like Portlock's hypotype but much smaller]; Carboniferous, Killymeal, Dungannon, Co. Tyrone, N. Ireland.

1969 Solemya (Janeia) primaeva (Phillips); Cox, p. N243, fig. B1,1a [topotype, Pr3, Bts, PAe; copy of Hind, 1900, pl. 50, fig. 5]; Lower Carboniferous limestone, Lowick, Northumberland, England.

1986 Solemya (Janeia) primaeva (Phillips); Zhang and Pojeta, p. 670, fig. 5.4 [Pr3, PAe, Bts(weak)]; Lower Carboniferous (Viséan), China.

2011 Acharax primaeva (Phillips); Bailey, 2011, p. 30

2013 Janeia primaeva (Phillips); Nevesskaja, et al., p. 90 , pl. 12, fig. 12.5 [copy of Hind, 1900, pl. 50, fig. 5].

Acharax costellata (M'Coy, 1844) sp. inq.

Remarks. Needs further study. Reviewed by Bailey (2011, p. 30). Hind (1900, p. 441) compared the form as similar to $S$. primaeva but with radial ribs weak to obsolescent. M'Coy's (1844, p. 48) original description is limited; the holotype, figured both by M'Coy (1844) and by Hind (1900), is an ambiguous shell fragment. Possibly useful if Hind's (1900, in part, pl. 50, figs. 8-10, non fig. 7) hypotypes are given priority. If so, one of de Koninck's (1885, pl. 23, fig. 31) examples of Solemya saginata is a possible synonym. Compares with Acharax radiata (Meek and Worthen) but not with $A$. primaeva (Phillips).

? 1844 Sanguinolites costellatus M'Coy, p. 48, pl. 8, fig. 5 [nom. dub.; gen. et. sp. indet. Pr2; fragmentary; longiterminal half missing; hinge unknown; short radial ribs faint but limited to breviventral margin]; Carboniferous, Ireland.

non 1854 Solemya saginata de Ryckholt, ("1847”), p. 53, pl. 11, figs. 9, 10 [= Dystactella cf. subnasuta]; l'argile carbonifère, Antoing, Belgium.

? 1885 Solemya saginata de Ryckholt; de Koninck, p. 121, pl. 23, figs. 31 [Pr2, Pc Ne?], 32? [Pr2, Pc]; Lower Carboniferous (Tournaisian), calcaire carbonifère, Tournai, Belgium.

? 1900 Solemya costellata M'Coy; Hind, p. 442, pl. 50, fig. 13 [Pr2, fragmentary; gen. et sp. indet.; Hind's own figure of M'Coy's (1844) holotype]; Carboniferous, Killyclogby, Lisbellaw, Co. Tyrone, N. Ireland.

p 1900 Solenomya costellata; Hind, p. 442, pl. 50, fig. 8 [Pr2, PAe], fig. 9 [Pr3, Bts?], fig. 10 [Pr2]; non fig. 7; Lower Carboniferous, Lowick and Redesdale, Northumberland, England.

? p 1900 Solemya excisa de Koninck; Hind, p. 441, pl. 50 figs. 12, 16 [Pc, Pr2, Bts, PAe, = Acharax cf. costellata]; Carboniferous, Ardross, Scotland; non pl. 50, figs. 11, 14, 15 [ventrally embayed; Pc, Pr1; = Acharax cf. normalis sensu Howse]; Lower Carboniferous, Lowick, Northumberland. [See also Dystactella excisa (de Koninck)].

Acharax cf. normalis (Howse, 1848) n. comb.

Remarks. No figure accompanied Howse's (1848) description; his subsequent (1857a) figure is rudimentary and is, as he personally remarked, inaccurate; holotype lost. Useful if Logan's (1967, pl.10, figs. 13,14$)$ material is given priority. If so, Solemya excisa de Koninck of Hind (1900, in part, pl. 50 , figs. $11,14,15$ ) is a possible synonym.

? 1848 Solenimya normalis Howse, p. 244 [nom. dub.; description only; no figure; radii described as lacking]; Upper Permian, Magnesian Limestone, Humbleldon Hill Quarry, Durham, England.

non 1848 Solemya phillipsiana King, p. 11 [allegedly fictitious (nom. nud.) but accepted by King as senior synonym of $S$. normalis Howse].

non 1850 Janeia phillipsiana King; King, p. 179, pl. 16, fig. 8 [description and figure, allegedly fictitious (nom. nud.) but accepted by King as senior synonym of $S$. normalis Howse]. 
? 1857a Solemya normalis Howse; Howse, p. 25, pl. 4, fig. 7 [Pr1; nom. dub.; rudimentary drawing; anterior margin described by Howse as inaccurate; holotype lost]; Upper Permian, Magnesian Limestone, Humbledon Hill, Durham, England.

? 1861 Solemya normalis Howse; Geinitz, p. 61, pl. 12, figs. 20, 21? [gen. et sp. indet; prosopon with fine comarginal growth lines and a few obsolescent radii]; Upper Permian (lower Zechstein), Thieschitz bei Gera, Germany.

non 1894 Solemya normalis Howse; Netschajew, p. 303, pl. 10, fig. 7 [gen. et sp. indet.; possible edmondiid?]; Permian, Volga River, mouth of Kama, Russia.

? p 1900 Solenomya excisa de Koninck; Hind, pl. 50, figs. 11, 14, 15, [ventrally embayed; Pc, Pr1; = Acharax cf. normalis]; Lowick, Northumberland; non pl. 50, figs.12, 16 [= Acharax cf. costellata]; Carboniferous, Ardross, Scotland. [See also Dystactella excisa (de Koninck)].

1967 Janeia normalis (Howse); Logan, p. 61, pl. 10, figs. 13, 14 [best published examples; Pr1, Le]; Upper Permian, Middle Magnesian Limestone, Tunstall Hill, Durham, England.

? 1978 Janeia normalis (Howse); Kłapciński and Karwowski, p. 73, pl. 3, figs. 1, 2 [Bts?; = aff. Acharax]; Upper Permian (middle Zechstein), Main Dolomite, Stassfurt Cyclothem, Poland.

non 1981 Solemya (Janeia) normalis (Howse); Muromtseva, p. 29, pl. 10, fig. 18 [Pc, PrO; very small, gen. et sp. indet; possible edmondiid? or nuculoid?]; Upper Permian, Novaya Zemlya.

non 1984 Solemya (Janeia) normalis (Howse); Muromtseva and Guskov, p. 35, pl. 24, fig.15, Seregovo, Komi Republic, Russia; pl. 41,fig. 18 $[\mathrm{Pc}, \mathrm{PrO}$; very small, gen. et sp. indet.; edmondiid?]; Upper Permian (Kazanian) Novaya Zemlya.

Acharax radiata (Meek and Worthen, 1860)

Remarks. Figures, missing in Meek and Worthen's (1860) original publication, were later added by the same authors (1866, pl. 26, figs. 10a-b). Compares with A. costellata (M'Coy), $A$. herberti (Růžička and Řehoř), and A. cylindrica (Hind), but not with A. primaeva s. s. Widely accepted; reviewed by Pojeta (1988) and Bailey (2011).

1860 Solemya radiata Meek and Worthen, p. 457 [no figure]; Pennsylvanian Coal Measures, Grayville, Illinois; [figure published by the authors in 1866].

1866 Solenomya radiata Meek and Worthen; Meek and Worthen, p. 349, pl. 26, fig. 10a-b [Pr2, $\mathrm{Ne}$; Pennsylvanian Coal Measures, Schuyler Co., Illinois.
? 1872 Solenomya sp. Meek, pl. 2, fig. 12a-b [figures only; no description; partial internal mold with attached shell fragment; $\mathrm{PrO}, \mathrm{Bts}$ ?, $\mathrm{Ne}$ ?];

Pennsylvanian, Upper Coal Measures, Rock Bluff, Nebraska.

1877 Solenomya radiata Meek and Worthen; Miller, p. 204 [no figure].

1889 Solenomya radiata Meek and Worthen; Miller, p. 512 [no figure].

1896 Solemya radiata Meek and Worthen; Hind, p. 32 [no figure].

1900 Solenomya radiata Meek and Worthen; Beede, p. 160, pl. 22, fig. 5-5a [Pr2-3, Ne?; copy of Meek and Worthen's description]; Pennsylvanian, Topeka, Kansas.

1922 Solenomya radiata Meek and Worthen; Morningstar, p. 193-194 [description but no figure]; Pennsylvanian, lower Mercer Limestone, Muskingum Co., Ohio.

non 1930 Solenomya radiata? Meek and Worthen; Branson (?Branson), p. 41, pl. 9, figs. 21, 22 [PrO, Pc0; featureless cast of an internal mold, gaping (?) at both ends; ligament and hinge unknown; same specimen (UM 5275) tentatively called Solemya $s p$. by Ciriacks (1963); profile resembles Dystactella]; Upper Permian, Park City Formation, Ervay Member, near Cody, Wyoming.

1961 Solemya radiata Meek and Worthen; Hoare, p. 94, pl. 12, fig. 12 [Pr2]; Middle Pennsylvanian (Desmoinesian), Tiawah Limestone, St. Clair Co., Missouri.

? 1961 Solemya sp. Hoare, p. 96, pl. 12, fig. 13 [Bts, PAe; partial internal mold; possibly Acharax radiata?]; Middle Pennsylvanian (Desmoinesian), Seville Limestone, Henry Co., Missouri.

1979 Solemya (Janeia) radiata (Meek and Worthen); Hoare, Sturgeon and Kindt, p. 29, pl. 2, fig.12 [Pr2], fig. 13? [Pr2]; Middle Pennsylvanian, Putnam Hill Shale, Ohio.

1983 Solemya (Janeia) radiata (Meek and Worthen); Kues, p. 80 [no figure]; Middle Pennsylvanian, Upper Los Moyos Limestone, Cedro, New Mexico.

1988 Solemya radiata Meek and Worthen; Pojeta, p. 215, pl. 22, figs. 1, 2, 5 [Pr3], fig. 4 [Pr3, Bts], Pennsylvanian Coal Measures, New Lisbon, Ohio; pl. 22, fig. 3 [Pr2], Pennsylvanian, Schuyler Co., Illinois; figs. 6, 7 [Pr2], fig. 10 [Pr3], pl. 23, figs. 1, 2 [Pr2], figs. 3, 4 [Pr2, Bts, PAe]; Pennsylvanian, Henry Co., Missouri.

non 1988 Solemya radiata Meek and Worthen; Pojeta, pl. 24, figs. 2, 3 [Pr1, Bts, PAe]; Pennsylvanian, Illinois?; figs. 4, 6 [Pr2, Bts, PAe; = 
Acharax (Nacrosolemya) trapezoides]; Pennsylvanian, Kansas City, Missouri.

1992 Solemya radiata Meek and Worthen; Kues, p. 91, figs. 2.7, 2.8 [Pr3, Bts, PAe]; Upper Pennsylvanian, basal limestone, Kinney Quarry, Manzanita Mts., New Mexico.

1997 Solemya radiata Meek and Worthen; Cope, pl. 1, fig. 10 [Pr3, Le(?)]; Upper Carboniferous, Ohio.

1997 "Solemya" radiata Meek and Worthen; Bailey and Sroka, p. 101, fig. 8A.2, C-E [Pr2, Le]; Middle Pennsylvanian (Westphalian D), Francis Creek Shale, Carbondale Formation, WillKankakee counties, Illinois.

2011 Acharax radiata (Meek and Worthen); Bailey, 2011, p. 27, pl. 3, figs. 1-6, 9; pl. 4, figs. 1-7 [based on topotypes; Pr2-3, Bts, PAe, Ne, Le, IG, PE]; Middle Pennsylvanian (Westphalian D), Francis Creek Shale, Carbondale Formation, Will-Kankakee and Fulton counties, Illinois.

Acharax (Nacrosolemya) trapezoides (Meek, 1874)

Remarks. First published as a figure (Solenomya sp. undet. Meek and Worthen, 1873, pl. 27, fig. 1ab); later named by Meek (1874, p. 583) but only briefly characterized. Beede and Rogers (1899, p. 132) gave the first detailed description. Reviewed by Pojeta (1988) and Carter (1990); lectotype nominated by Bailey (2011).

1873 Solenomya sp. undet. Meek and Worthen, pl. 27, fig. 1a-b [Pc, PrO, Ne, Dp]; same specimen (USNM 36315; labeled, "Coal Meas. Illinois?") later figured by Bailey (2011, p. 31, pl. 5, figs. 1-5) and nominated as lectotype of Acharax trapezoides (Meek and Worthen)].

1874 Solenomya sp. undet. Meek, p. 582 [ref. Meek and Worthen, 1873, pl. 27, fig 1a-b].

1874 Solenomya (Janeia) trapezoides Meek, p. 583 [ref. Meek and Worthen, 1873, pl. 27, fig 1a-b].

1899 Solenomya trapezoides Meek; Beede and Rogers, p. 132, pl. 34, fig. 2a-b [Pc, PrO/Pr1, Bts, PAe, Ne, IG]; Pennsylvanian, Coal Measures, Westport, Missouri, and Porterville, Kansas.

1900 Solenomya trapezoides Meek; Beede, p. 159, pl. 21, fig. 2a-b [Pc, PrO, Bts, PAe, Ne]; near junction of Upper and Lower Coal Measures, Porterville, Kansas, and Westport, Missouri.

? 1961 Solemya trapezoides Meek; Hoare, 1961, p. 96, pl. 12, fig. 14 [PrO; few details; more smoothly rounded than other $A$. (N.) trapezoides]; Weir-Pittsburg Coal, Henry Co., Missouri.
? 1979 Solemya (Janeia) trapezoides Meek; Hoare, Sturgeon and Kindt, p. 30, pl. 2, figs.14? (fragment), 15? (fragment), 16, 17 [Pc]; Pennsylvanian, Putnam Hill Shale, Ohio.

1988 Solemya trapezoides Meek; Pojeta, p. 215, pl. 22, figs. 8, 9 [Pr1, Bts, PAe,]; Pennsylvanian, Henry Co., Missouri; pl. 24, fig. 1? [Pr2, Bts, PAe]; Pennsylvanian, Beatrice, Nebraska; pl. 24, fig. 5? [Pr2, Bts, PAe]; Pennsylvanian, Clover Land, Clay Co., Indiana; pl. 24, figs. 7, 8 [Pr1, Bts, PAe]; Pennsylvanian, Kansas City, Missouri.

1988 Solemya sp. Pojeta, pl. 23, figs. 5-8 [Pr1, Bts, $\mathrm{PAe}, \mathrm{Ne}, \mathrm{IG}$; Pennsylvanian, Hertha Limestone, Kansas.

? 1988 Acharax? sp. Pojeta (?Pojeta), pl. 20, fig. 9 [left internal mold; Pc, Pr1, PAe, Bts(weak); compares with A. (N.) trapezoides]; Permian, near Wymore, Nebraska.

1990 Acharax (Nacrosolemya) trapezoides (Meek); Carter, 1990, p. 174, figs. 17, 18 [PrO/Pr1, Le, Ne]; Upper Carboniferous, Breathitt Formation, Eastern Kentucky.

1992 Solemya trapezoides Meek; Kues, p. 93, fig. 2.9 [Pc, Bts?, Ne], fig. 2.10 [Pc, Pr1]; Upper Pennsylvanian, basal limestone, Kinney Quarry, Manzanita Mts., New Mexico.

1997 Acharax (Nacrosolemya) trapezoides (Meek); Bailey and Sroka, p. 102 [no figure].

2002 Solemya trapezoides Meek; Kues et al., 2002, p. 129, fig. 4Q [Pc]; Upper Pennsylvanian, Derry Hills, New Mexico.

? 2003 Solemya trapezoides Meek; Krainer, et al., 2003, fig. 7L [Pc, PrO Le; Bts; poorly preserved composite mold; shell profile short and rounded, nearly ovoid; intermediate (?) between $A$. trapezoides and $A$. radiata]; Upper Pennsylvanian, Zuni Mts., New Mexico.

2011 Acharax (Nacrosolemya) trapezoides (Meek); Bailey, p. 31, text-fig. 3, Middle Pennsylvanian, Carbondale Formation, Canton, Illinois; pl. 5, figs.1-5; = lectotype, USNM 36315, "Coal Meas., Illinois?" [Pc, Pr1, Bts, PAe, Ne, IG]; pl. 5, fig. 6 [Pr1]; Middle Pennsylvanian, Carbondale Formation, Will Co., Illinois.

\section{Acharax parallela (Beede and Rogers, 1899)}

Remarks. Junior homonym of Solemya parallela de Ryckholt. Known mostly from original designation by Beede and Rogers (1899). Subsequent reports are questionable. Compares with $A$. primaeva (Phillips) (see Bailey, 2011, p. 30, 37). Logan's (1967, in part) example of Janeia biarmica is a possible synonym. 
non 1853 Solemya parallela de Ryckholt, (“1854”), p. 51, pl. 11, figs., 11, 12 [senior homonym; not a solemyid; = Wilkingia?, i.e., W.? aff. abramovi Muromtzeva in Biakov, 2019, pl. 3, fig. 20]; Lower Carboniferous, (Tournaisian) l'argile carbonifère, Tournai, Belgium.

1899 Solenomya parallela Beede and Rogers, $\mathrm{p}$. 131, pl. 34, fig. 1 [Pr3, Bts, PAe]; Pennsylvanian Coal Measures, Kansas City and Lawrence, Kansas.

? 1952 Solemya (Janeia) parallela (Beede and Rogers); Chronic, p. 153 [fragmentary, no figure]; Middle Permian, Kaibab Formation, Arizona.

? p 1967 Janeia biarmica (de Verneuil, 1845); Logan, p. 60 , pl. 10, fig. 12 [Le, IG], non fig. 11; Upper Permian, Tunstall Hill, Durham, England.

? 1986 Solemya (Janeia) parallela (Beede and Rogers); Zhang and Pojeta, p. 669, fig. 5.14 [PAe; shorter than expected for A. parallela; compares with $A$. radiata and $A$. costellata]; Lower Carboniferous, Ceshui Formation, China.

2011 Acharax parallela (Beede and Rogers); Bailey, 2011, p. 30, 37 [possible variant (?) of Acharax primaeva (Phillips)].

Acharax cylindrica (Hind, 1907) n. comb.

Remarks. Poorly known. The syntype (BGS GSE6465) clearly shows a simple buttress and entire posterior adductor scar. Radii weak; compares with $A$. costellata (M'Coy) and $A$. radiata (Meek and Worthen).

1907 Solemya cylindrica Hind, p. 351, pl. 2, figs. 60, 61 [Pr1; Bts?]; Carboniferous (Namurian), Millstone Grit, Coatbridge, Dumbartonshire, Scotland [ref.: BGS GSE6465

(syntype), Pr1, Bts, PAe; labeled "Solemya costellata?" (McCoy), Carboniferous (Namurian), Millstone Grit, Gain Quarry, Glenboig, Lanarkshire, Scotland.

Acharax holmwoodensis (Dickins, 1963) n. comb.

Remarks. Useful but not widely studied.

1963 'Solemya' holmwoodensis Dickins, p. 59, pl. 7, figs. 1-9 [Pc, Pr1f(internal), Bts, Le, Ne]; pl. 8, figs. 17, 18; Lower Permian (Sakmarian) Holmwood Shale, W. Australia.

Acharax herberti (Růžička and Řehor, 1978) n. comb.

Remarks. Shell compares in profile to both $A$. radiata and $A$. costellata, but radial ribs are more conspicuous; J. herberti has priority; J. leosi, J. mariae, and $J$. talboti are probable synonyms; differences are judged to be taphonomic in origin.
1978 Janacekia herberti Růžička and Řehor, p. 63, pl. 1, figs. 1-8; pl. 2, figs. 1-8; pl. 3, figs. 1-13; pl. 4, figs. 2-9; pl. 5, figs. 1-9; pl. 11, fig. 1; pl. 14, fig. 6; [Pc, Pr3, Bts, PAe, Le]; Carboniferous, Ostrava Schichtengruppe, Upper Silesian Coal Basin, Czech Republic.

1978 Janacekia leosi Růžička and Řehor, p. 66, pl. 4, fig. 1; pl. 6, figs. 1-12; pl. 7, figs. 1-10; pl. 8, figs. 1-9; pl. 9, figs. 1-9; pl. 10, figs. 1-10; pl. 11, figs. 2-6; pl.12, figs. 1-10; pl. 13, figs. $1-$ 10; pl. 14, figs. 2, 8; pl. 15, figs. 2-4; [PP?, Pc, Pr3, Bts, PAe, Le, Ale ]; Carboniferous, Ostrava Schichtengruppe, Upper Silesian Coal Basin, Czech Republic.

1978 Janacekia mariae Růžička and Řehor, p. 69, pl. 14, figs. 1, 3, 5; pl. 16, figs. 1, 2 [PP?, Pc, Pr3, Bts]; Carboniferous, Ostrava Schichtengruppe, Upper Silesian Coal Basin, Czech Republic.

1978 Janacekia talboti Růžička and Řehor, p. 69, pl. 14, figs. 4, 7 [Pc, Pr3]; Carboniferous, Ostrava Schichtengruppe, Upper Silesian Coal Basin, Czech Republic.

Acharax solikamica (Muromtseva, 1981) n. comb.

Remarks. Compares with $A$. radiata, A. costellata, and $A$. herberti. Ligament described by Muromtseva (1981, p. 30) as posteriorly placed, external.

1981 Solemya (Janeia) solikamica Muromtseva, p. 30, pl. 7, figs. 12, 16, 17 [Le, Pr2/3]; Upper Permian, North European part of Russia.

1984 Solemya (Janeia) solikamica Muromtseva; Muromtseva and Guskov, p. 35, pl. 24, figs. 11, 13, 14 [Pr2, Bts]; Upper Permian, West Verkhoyansk, Russia; pl. 37, figs. 9?, 11, 12 [Pr2; Bts?, PAe?]; Permian, Novaya Zemlya.

Acharax? petschorica (Guskov, 1984) n. comb.

? 1984 Solemya (Janeia) petschorica Guskov (in Muromtseva and Guskov, 1984), p. 35, pl. 24, fig. 10 [Pr2, Bts? PAe?; possible Acharax]; Lower Permian (Kungurian), Pechora Basin, Russia.

Acharax sp. Pojeta, 1988

Remarks. Three shell fragments; two indeterminate, showing only prosopon; a third showing external nymph, small buttress (simple) and posterior adductor (entire).

p 1988 Acharax sp. Pojeta, pl. 20, fig. 6? [indet. fragment, Pc, Prs, Pr2-3], fig. 7? [indet. fragment, Pc; Pr2-3], pl. 20, fig. 8, pl. 23, fig. 9 [fragment, Le(with insertion groove), Bts, Pae]; Lower Permian, Bone Springs Limestone, Sierra Diablo, Texas.

aff. Acharax incertis (Dickins, 1999) n. comb. 
Remarks. Unnamed new solemyid genus; wellpreserved impressions of adductor musculature; anterior adductor clearly showing visceral retractor band. Like Acharax but distinguished by thickened, finely dentate hinge plate.

1999 Janeia? incertis Dickins (?Dickins), 1999, pl. 1, figs. 13-18 [Bts, PAe, IG, Ne (traces)]; Middle Permian, Khuff Formation, Oman.

Acharax sp. Bailey, 2011

Remark. Unnamed new species.

1988 Solemya (Janeia) sp. Prosh, 1988, p. 162, pl. 23, fig. 4; Lower Devonian, Disappointment Bay Formation, Young Island, Nunavut, Canada.

2011 Acharax [sp.] Bailey, 2011, p. 26, pl. 3, fig. 7 [Pr2, Bts, PAe, IG]; Lower Devonian, Disappointment Bay Formation, Young Island, Nunavut, Canada.

2016 Acharax sp. Bailey and Prosh, abst. 12-12.

2016 Acharax sp. Bailey, abst. 118-2.

Subfamily CLINOPISTHINAE Pojeta, 1988 Genus CLINOPISTHA Meek and Worthen, 1870

Type species. By monotypy, Clinopistha radiata var. levis Meek and Worthen, 1870, p. 44 (= Clinopistha levis Meek and Worthen, 1870, p. 45); Coal Measures (Pennsylvanian), west-central, Illinois. Reviewed by McAlester (1968, p. 20) and Pojeta (1988, p. 216).

Clinopistha truncata (Golfuss, 1840) n. comb.

Remarks. Beushausen's type (Sanguinolaria truncata Goldfuss, 1840) is a generically indeterminate shell fragment. Useful if Beushausen's (1895, pl. 26 , figs. 4,5$)$ topotypes are given priority. Compares with certain examples of Clinopistha levis showing fine prosoponal radii, especially on the inner surface of the shell (e.g., Pojeta, 1988, pl. 9, fig. 8; pl. 11, figs. 1-9).

? 1840 Sanguinolaria truncata Goldfuss, p. 279, pl. 159, fig. 13a, b; [gen. et sp. indet.; breviterminus encased in matrix; poorly exposed; possibly not a solemyid]; Devonian, Eifel.

? 1858b Edmondia? radiata Hall (?Hall); p. 716, pl. 29, fig. 3 [Pr1; = Clinopistha; like C. levis Meek and Worthen $(1870$, p. 45$)$ but fine prosoponal radii more pronounced; holotype lost]; Coal Measures (Pennsylvanian), lowa.

p 1895 Janeia truncata (Goldfuss); Beushausen, p. 296, pl. 26, figs. 4, 5, [Pr1f; like C. levis but prosoponal radii more pronounced; non textfig. 32, p. 297]; Devonian, Eifel and Gerolstein, Germany.
1930 Janeia truncata (Goldfuss); Quenstedt, pl. 1, figs. 4, 5, Middle Devonian, Gerolstein, Germany.

1969 Solemya (Janeia) truncata (Goldfuss); Cox, 1969, p. N243, fig. B1,1b (copy of Quenstedt, 1930, pl. 1, fig. 4).

Clinopistha abbreviata (de Ryckholt, 1854)

Remarks. Ligament posterodorsal, parivincular, external. Compares with Clinopistha levis Meek and Worthen, 1870; Hind (1900, p. 447) agreed.

1854 Solemya abbreviata de Ryckholt, p. 53, pl. 16, figs. 18, 19 [short, anteroventrally extended shell, PrO, Le]; Lower Carboniferous, (Tournaisian) Tournai, Belgium.

1885 Clinopistha abbreviata (de Ryckholt); de Koninck, pl. 14, figs. 48-50; pl. 23, figs. 15-19 [short, anteroventrally extended shell; $\operatorname{Pr} 0$, Le]; Lower Carboniferous, (Tournaisian), calschiste de Tournai, Belgium.

1900 Clinopistha abbreviata (de Ryckholt); Hind, p. 446, pl. 50, fig. 17; Lower Carboniferous, Fourlaws Limestone, Coombs Quarry, Redesdale, Northumberland.

Clinopistha curta (Walcott, 1884) n. comb.

Remarks. Name originally applied to two different taxa: Walcott (1884, pl. 22, fig. 6) is Clinopistha, i.e., C. cf. levis Meek and Worthen, but pl. 22, fig. 11 is probably Dystactella, i.e., D. cf. subnasuta (Hall and Whitfield). By priority, the trivial name, curta, is herein assigned to Clinopistha as it appears first on Walcott's plate 22 .

p 1884 Solenomya curta Walcott, p. 242, pl. 22, fig. 6 [Pc, Pr1; = Clinopistha cf. levis Meek and Worthen], non fig. 11 [Pc, Pr1; = Dystactella cf. subnasuta (Hall and Whitfield, 1872)]; Lower Carboniferous, Eureka District, Nevada.

? 1889 Solenomya curta Walcott; Miller, p. 512 [no figure]; Subcarboniferous, Nevada.

Clinopistha? kasanensis (Netschajew, 1894) n. comb.

Remarks. Generic identity of the Netschajew's (1894) type material (internal molds) is questionable; shell profiles resemble Clinopistha but diagnostic characters are lacking. Kłapciński and Karwowski's (1978) specimen is indeterminate, whereas examples of Muromtseva (1981) and Muromtseva and Guskov (1984) appear to be edmondiids.

? 1894 Solemya (Janeia) kasanensis Netschajew, p. 304, pl. 10, fig. 16 [possible Clinopistha?]; Volga River, mouth of the Kama; pl. 10, fig. 20? [gen. indet.], Permian, Krasnowidowo, Volga River, Russia; pl. 10, fig. 21 [possible 
Clinopistha?]; Permian, Bogorodskoye, Volga River, Russia.

? 1978 Janeia kasanensis (Netschajew); Kłapciński and Karwowski, p. 73, pl. 2, fig. 14 [internal mold; Bts?; gen. indet.]; Upper Permian (middle Zechstein), Main Dolomite, Stassfurt Cyclothem, Poland.

non 1981 Solemya (Janeia) kasanensis Netschajew; Muromtseva, p. 30, pl. 10, fig. 17 [gen. indet.; possible edmondiid]; Upper Permian, Novaya Zemlya.

non 1984 Solemya (Janeia) kasanensis Netschajew; Muromtseva and Guskov, p. 35, pl. 41, fig. 17 [gen. indet.; possible edmondiid]; Permian, Novaya Zemlya.

Genus DYSTACTELLA Hall and Whitfield, 1872 [= Palaeosolemya Pojeta and Runnegar, 1985]

Type species. By monotypy, Tellinomya subnasuta Hall and Whitfield, 1872, lower Givetian (upper Middle Devonian) near Louisville, Kentucky.

Dystactella biarmica (de Verneuil, 1845) n. comb.

Remarks. Holotype of de Verneuil (1845) is an internal mold with profile and ligament (external, parivincular) similar to Dystactella subnasuta (Hall and Whitfield). Shell exterior and prosopon not preserved in the holotype. Judged by Meek (1871, p. 67 ) to be possible synonym of Solemya (Janeia) vetusta Meek (= Dystactella; see below). Solemya saginata of de Ryckholt 1854 is a possible synonym.

1845 Solemya biarmica de Verneuil, p. 294, pl. 19, fig. 4a-b [IG, Le]; Lower Permian, Nizhny Novgorod Oblast, Russia.

? 1848 Solemya biarmica de Verneuil; Geinitz, p. 8, pl. 3, fig. 34. [Tiny oval shell with low umbos; gen. et sp. indet.] Upper Permian, Kupferschiefer, Kamsdorf, Germany.

non 1850 Janeia biarmica (de Verneuil); King, p. 178, pl. 16, fig. 7 [= probable pholadomyid, i.e., Wilkingia elegans (King); see Logan, 1967, p. 63]; Upper Permian, Humbledon Hill, Durham, England.

? 1854 Solemya saginata de Ryckholt, p. 53, pl. 11, figs. 9, 10 [Pc, PrO; = Dystactella cf. subnasuta; compares with Pojeta (1988, pl. 8 figs. 1, 2)]; Lower Carboniferous, (Tournaisian), l'argile carbonifère, Tournai, Belgium.

non 1858 Solemya biarmica? de Verneuil; Howse (?Howse), p. 266, pl. 11, figs. 8, 9 [formerly, Solenimya abnormis Howse, 1848, and Solemya abnormis Howse, 1857a] [= Stutchburia? cf. modioliformis (King) sensu Logan (1967, p. 51)]; Upper Permian, Silksworth, Durham, England.
? 1860 Solenomya biarmica? de Verneuil; Swallow and Hawn (?Swallow and Hawn), p. 190. [Material described as "imperfect"; no description, no figure; Swallow was doubtful about generic placement]; Upper Permian, Council Grove, Kansas.

p ? 1861 Solemya biarmica de Verneuil; Geinitz, p. 60, pl. 12, fig. 18 [Pc; shell form fairly consistent with $D$. biarmica; ligament unknown]; Upper Permian, Zaufensgraben bei Gera, Germany; non pl. 12, fig. 19 [= type of Solemya phllipisiana sensu Schauroth]; Upper Permian (lower Zechstein), Bucha, Germany.

non 1866 Solemya biarmica de Verneuil; Geinitz, p. 15, pl. 1 fig. 22; [gives size but no description; hinge, ligamental and interior uknown; the smoothly ovoid profile, pointed subcentral umbo, and fasciculate comarginal growth laminae are unlike known solemyids; gen. et sp. indet.] Pennsylvanian, Plattsmouth Limestone Member, Oread Limestone, Nebraska City, Nebraska.

1877 Solenomya biarmica de Verneuil; Miller, p. 204 [no figure].

1889 Solenomya biarmica de Verneuil; Miller, p. 512 [no figure].

non 1894 Solemya biarmica de Verneuil; Netschajew, p. 302, pl. 10, fig. 13 [gen. et. sp. indet.; probably not a solemyid]; Permian, Volga River at the mouth of the Kama.

1896 Solemya biarmica de Verneuil; Hind, p. 24, 36 [no figure].

non 1897 Solemya (Janeia) biarmica (de Verneuil); Diener, p. 173, pl. 8, figs. 7, 8 [= Sanguinolites? M'Coy, 1844]; Upper Permian, Kuling Shales, south of Pomerang, India.

? 1967 Janeia biarmica (de Verneuil); Logan, p. 60, pl. 10, fig. 11?, fig. 12? [possible Dystactella, sp. indet.; Pc, Ne, IG]; Upper Permian, Middle Magnesian Limestone, Tunstall Hill, Durham, England.

? 1978 Janeia biarmica (de Verneuil); Kłapciński and Karwowski, p. 72, pl. 2, figs. 12, 13; [poor preservation; gen. et sp. indet.]; Upper Permian (middle Zechstein), Main Dolomite, Stassfurt Cyclothem, Poland.

non 1984 Solemya (Janeia) biarmica (de Verneuil); Muromtseva and Guskov, p. 34, pl. 24, fig. 4a-b [= cf. Acharax sp.; PrO, Ne, Bts?, IG]; non fig. 5 [gen. et sp. indet]; fig. 6a-b [= clinopisthin, cf. Clinopistha sp.; Pc, Ne, IG]; fig. 7 [= Dystactella?]; Lower Permian (Kungurian), Pechora Basin, Russia.

Dystactella vetusta (Meek, 1871) n. comb.

Remarks. Judged by Meek (1871, p. 67) to be possible synonym of Solemya biarmica de Ver- 
neuil. Pojeta (1988, p. 217) placed Hall's (1885) examples of Dystactella vetusta (Meek) in Dystactella valvulus (Hall and Whitfield). See D. valvulus (below).

1871 Solemya (Janeia) vetusta Meek, p. 66 [description only; no figure]; Devonian, Corniferous Group, Dublin, Franklin Co., Ohio.

1873 Solemya (Janeia) vetusta Meek; Meek, p. 206, pl. 18, fig. 4 [Pr1, Ne]; Devonian, Corniferous Group, Dublin, Franklin Co., Ohio.

1877 Solenomya vetusta Meek; Miller, p. 204 [no figure].

1878 Solenomya vetusta Meek; Bigsby, p. 76 [no figure]; Corniferous Limestone, Dublin, Franklin Co., Ohio.

non 1885 Solemya (Janeia) vetusta Meek; Hall, p. 463, pl. 45, figs. 53-55; pl. 94, fig. 10 [= Dystactella valvulus (Hall and Whitfield); see Pojeta, 1988, p. 217].

1889 Solenomya vetusta Meek; Miller, p. 512, fig. 922 [figure copied from Meek, 1873, pl. 18, fig. 4].

1890 Solemya (Janeia) vetusta Meek; Lesley, p. 972 [figure copied from Meek, 1873, pl. 18, fig. 4].

1901 Solemya (Janeia) vetusta Meek; Kindle, p. 690, pl. 16, figs. 1, 1a-b, 2 [Pc, Pr1, Ne, IG]; Middle Devonian, Sellersburg beds; Watson, Indiana, and Falls of the Ohio.

non 1944 Solemya? vetusta Meek; Shimer and Shrock (?Shimer and Shrock), p. 369, pl. 44, figs. 1, 2 [with figure copies of Hall, 1885, pl. 47, figs. 53, 55; Pojeta (1988, p. 217) referred these to Dystactella valvulus.]; Middle Devonian (Onondaga-Hamilton), New York, Pennsylvania, Ohio, Indiana, Kentucky.

Dystactella cf. subnasuta Hall and Whitfield, 1872

Remarks. Dystactella subnasuta Hall and Whitfield was reviewed by Pojeta (1988, p. 217); items in his brief synonymy are omitted here as none were referred either to Solemya or Janeia.

p 1884 Solenomya curta Walcott, p. 242, pl. 22, fig. 11 [Pc, Pr1; = Dystactella cf.subnasuta (Hall and Whitfield, 1872); hinge, ligament and interior unknown]; non pl. 22, fig. 6 [Pc, Pr1; = Clinopistha cf. levis Meek and Worthen]; Lower Carboniferous, Eureka District, Nevada.

? 1889 Solenomya curta Walcott; Miller, p. 512 [no figure]; Subcarboniferous, Nevada.

Dystactella valvulus (Hall and Whitfield, 1872)

Remarks. Reviewed by Pojeta (1988, p. 217). Hall (1885) placed Yoldia? vetusta Hall and Whitfield in synonymy with Solemya (Janeia) vetusta Meek. Pojeta (1988, p. 217) placed Hall's (1885) examples of Dystactella vetusta (Meek) in Dystactella valvulus (Hall and Whitfield). See $D$. vetusta (above).

non 1871 Solemya (Janeia) vetusta Meek, p. 66 [description only; no figure]; Devonian, Corniferous Group, Dublin, Franklin Co., Ohio.

1872 Yoldia? valvulus Hall and Whitfield (?Hall and Whitfield), p. 190 [description only; figures published in Hall and Whitfield, 1875, pl. 11, figs. 18-20]; Middle Devonian, Hydraulic Beds near Louisville, Kentucky.

non 1873 Solemya (Janeia) vetusta Meek; Meek, p. 206, pl. 18, fig. 4 [Pr1, Ne]; Devonian, Corniferous Group, Dublin, Franklin Co., Ohio.

1875 Yoldia? valvulus Hall and Whitfield (?Hall and Whitfield), pl. 11, figs. 18-20 [Pc, Ne; figures to accompany description in Hall and Whitfield, 1872, p. 190].

1883 Yoldia? valvulus Hall and Whitfield (?Hall and Whitfield); Hall, pl. 47, figs. 53-55 [Pc, Ne; figures copied from Hall and Whitfield, 1875, pl. 11, figs. 18-20].

1885 Solemya (Janeia) vetusta Meek; Hall, p. 463, pl. 47, figs. 53-55 [Pc, Ne; figures copied from Hall and Whtifield, 1875, pl. 11, figs. 1820]; Middle Devonian Hamilton Group, near Louisville, Kentucky; pl. 94, fig. 10 [Prs, Ne]; Hamilton Group, Charlestown, Indiana.

1889 Yoldia? valvulus Hall and Whitfield (?Hall and Whitfield); Nettleroth, p. 223, pl. 4, figs. 4, 5 [Pc, PrO, Ne]; Devonian, from the cherty layers above the Hydraulic Limestone, Jefferson Co., Kentucky, and Clark Co., Indiana.

1944 Solemya? vetusta Meek; Shimer and Shrock (?Shimer and Shrock), p. 369, pl. 44, figs. 1, 2 [figures copied from Hall, 1885, pl. 47, figs. 53, 55], Middle Devonian (Onondaga-Hamilton), New York, Pennsylvania, Ohio, Indiana, Kentucky.

1988 Dystactella valvulus (Hall and Whitfield); Pojeta, p. 217, pl. 10, figs. 1-4 [Prs, Pr1, Ne; these specimens used by Nettleroth (1889) for his description and figures]; Middle Devonian (Lower Givetian), Silver Creek Limestone Member, Falls of the Ohio, Clark Co., Indiana.

Dystactella excisa (de Koninck, 1885)

Remarks. A species of Dystactella with large, welldefined external ligament on the brevidorsum. The lost undescribed (nom. nud.) specimen of Solemya symesii figured by Baily (1880) is nearly identical to de Koninck's $(1885$, pl. 9, figs. 13, 14) type of Solemya excisa; other specimens of de Koninck 
attributed to $S$. excisa are indeterminate. Because the trivial name, excisa, is applied first to pl. 9, figs. 13,14 , it is here given priority.

1880 Solemya symesii Baily, p. 22. [no description (nom. nud.); based on two unnumbered figures of a single specimen, now lost; strong external ligament; similar to de Koninck's (1885, pl. 9 figs. 13, 14) examples of Solemya excisa]; lower limestone series, Easky, Bunowna, Co. Sligo, Ireland.

p 1885 Solemya excisa de Koninck, p. 122, pl. 9, figs. 13,14 , pl. 23 , figs. $30,39,40$, non pl. 23 , fig. 42, 43 [gen. et sp. indet.]; Lower Carboniferous, (Tournaisian) calcaire carbonifère, Tournai, Belgium.

non 1900 Solemya excisa de Koninck; Hind, p. 441, non pl. 50 , figs. 11,14 ?, 15 [ventrally embayed; Pc, Pr1; = Acharax cf. normalis sensu Howse]; Lower Carboniferous, Lowick, Northumberland; non pl. 50 figs. 12, 16 [Pc, Pr2, Bts, PAe; = Acharax cf. costellata]; Carboniferous, Ardross, Scotland.

Dystactella? silurica (Liljedahl, 1984) n. comb.

Remarks. Possibly a new subgenus of Dystactella. Pojeta (1988) reassigned Janeia silurica to Dystactella, but because of its uniquely asymmetric ligament support structures, Bailey (2011, p. 20) suggested placement in a new genus very close to Dystactella s. s.].

1984a Janeia silurica Liljedahl, p. 28, figs. 4, 13-15, 34:5. Silurian (Upper Wenlockian), Halla beds, Mölbos, Gotland.

1984b Janeia silurica Liljedahl; Liljedahl, p. 693-698, text-figs. 1-3. Silurian (Upper Wenlockian), Halla beds, Mölbos, Gotland.

1988 Dystactella silurica (Liljedahl); Pojeta, 1988, p. 215.

1991 Janeia silurica Liljedahl; Liljedahl, p. 222, text-figs. 2E-G, 3.

1994 Janeia silurica Liljedahl; Liljedahl, p. 12, etc.

2011 Dystactella? silurica (Liljedahl); Bailey (?Bailey), 2011, p. 20; text-fig. 4.

Subclass AUTOBRANCHIA Grobben, 1894 Order HIATELLIDA Carter, 2011

Superfamily EDMONDIOIDEA King, 1850

Family EDMONDIIDAE King, 1850

Genus EDMONDIA De Koninck, 1842

Type species. By original designation, Isocardia unioniformis Phillips, 1836, Carboniferous, Bolland, Yorkshire.

Edmondia? soleniformis (Cox, 1857) new comb.

Remarks. Cox's (1857) type incomplete; umbo subcentral, broad and elevated; prosopon with reg- ular comarginal lirae, closely spaced and distinct; radii lacking; hinge, ligament and interior unknown. Placed in Solemya by Cox (1857), Keyes (1888) and Hind (1896). Not a solemyid; probable edmondiid: Edmondia?

? 1857 Solenimya soleniformis Cox, p. 573, pl. 9, fig. 5; [Pc(strong), Pr0; = Edmondia?]; Pennsylvanian, Coal Measures, Union Co., Kentucky.

1877 Solenomya soleniformis Cox; Miller, p. 204 [no figure].

1888 Solenomya soleniformis Cox; Keyes, 1888, p. 234 [no figure or description; Keyes compared it to Solenimya soleniformis sensu Cox but larger]; Lower Coal Measures (Pennsylvanian), Des Moines, lowa.

1889 Solenomya soleniformis Cox; Miller, p. 512 [no figure].

1896 Solemya soleniformis Cox; Hind, 1896, p. 29 [no figure].

Edmondia anodontoides (Meek, 1875)

Remarks. Studies prior to Morningstar (1922) placed the species in Solemya. Restudy of Hoare, Sturgeon, and Kindt (1979) accepted it as Edmondia.

1875 Solenomya? anondontoides Meek (?Meek), p. 339, pl. 19, fig. 11 [hinge, ligament and interior unknown; Meek called it a possible Edmondia]; Pennsylvanian, Newark, Ohio.

1877 Solenomya anodontoides, Meek; Miller, p. 204 [no figure].

1886 Solenomya anondontoides Meek; Claypole, p. 241-242 [no description, or figure]; Pennsylvanian, Wilkes-Barre, Pennsylvania.

1887 Solenomya? anodontoides Meek (?Meek); Herrick, p. 29, pl. 4, fig. 10 [Pc(strong); possible Edmondia, but hinge, ligament and interior unknown. Herrick was doubtful about generic placement]; Pennsylvanian, Flint Ridge, Ohio.

1889 Solenomya anodontoides Meek; Miller, p. 512 [no figure].

1922 Edmondia anodontoides? (Meek); Morningstar (?Morningstar), p. 196 [description/discussion but no figure; judged Meek's and Herrick's specimens to be disparate species]; Pennsylvanian, Perry Co., Ohio.

1979 Edmondia anodontoides (Meek); Hoare, Sturgeon and Kindt, p. 57, pl. 15, figs. 12-14; Pennsylvanian, Brush Creek, Ohio.

Edmondia meekiana (Herrick, 1887)

Remark. Solemya? meekiana Herrick subsequently accepted as Edmondia.

1887 Solenomya? meekiana Herrick (?Herrick), p. 30, pl. 4, fig. 9 [hinge, ligament, interior 
unknown; probable Edmondia. Herrick noted similarities to Edmondia reflexa Meek (1872, p. 233, pl. 4, fig. 7) but did not accept it as a synonym]; Pennsylvanian Coal Measures, Flint Ridge, Ohio.

1922 Edmondia meekiana? (Herrick); Morningstar (?Morningstar), p. 198, pl. 10, fig. 6; Pennsylvanian, Lower Mercer Limestone, Flint Ridge, Ohio.

? 1958 Edmondia meekiana (Herrick); Wanless, p. 44 [no figure]; Pennsylvanian, Liverpool Cyclothem, western Illinois.

1979 Edmondia meekiana (Herrick); Hoare, Sturgeon and Kindt, p. 58, pl. 16, figs. 6, 7; Pennsylvanian, Lower Mercer unit, Flint Ridge, Ohio.

? 1983 Edmondia aff. E. meekiana (Herrick); Kues (aff. Kues), p. 80 [no figure]; Middle Pennsylvanian, Upper Los Moyos Limestone, Cedro, New Mexico.

ORDER CARDIIDA Férussac, 1822 SUPERFAMILY KALENTEROIDEA Marwick, 1953 FAMILY KALENTERIDAE, Marwick, 1953 Genus PLEUROPHORELLA Girty, 1904

Type species. Pleurophorella papillosa Girty, 1904 by original designation, Graham Limestone, Pennsylvanian (Cisco), Young County, Texas.

Remarks. Janeia? compressa (Goldfuss) Beushausen (1895) and Janeia laevigata (Goldfuss) Beushausen (1895) are not solemyids; both are here provisionally placed in Pleurophorella. Shell posteriorly elongated, somewhat modioliform, laterally compressed with well-defined lunule and long escutcheon; hinges and internal morphologies unknown.

Pleurophorella? aff. transversa (de Koninck, 1842)

Remarks. Janeia? compressa (Goldfuss) Beushausen compares with Sanguinolaria compressa Goldfuss and with Pleurophorella transversa (de Koninck). Beushausen himself was uncertain about generic placement.

? 1840 Sanguinolaria compressa Goldfuss, 1840, p. 280, pl. 159, fig. 16a-b [= Beushausen's type of $J$.? compressa; hinge and interior unknown; well-defined lunule and long escutcheon]; Devonian, Uebergangskalk, Eifel.

? 1842 Cypricardia transversa de Koninck, p. 94, pl. 1, fig. 3, pl. 3, fig. 8? [compares with but not identical to S. compressa Goldfuss]; Lower Carboniferous, (Tournaisian), Tournai, Belgium.

1895 Janeia? compressa (Goldfuss); Beushausen (?Beushausen) 1895, p. 297, pl. 26, fig. 1a-c [compares with S. compressa Goldfuss; hinge and ligament unknown; Pr0]; Devonian, Daleiden, Germany.

? 1991 Pleurophorella transversa (de Koninck); Morris et al. (1991, p. 87, fig. 41) [compares with J.? compressa sensu Beushausen]; Lower Carboniferous, (Tournaisian) Tournai, Belgium.

\section{Pleurophorella? sp.}

Remarks. Beushausen's poorly exposed type of Janeia laevigata (i.e., Sanguinolaria laevigata Goldfuss) is indeterminate. Beushausen's (1895, pl. 26, fig. 2a-c) example of Janeia laevigata compares with Pleurophorella sp. Morris et al., 1991, fig. 40, Upper Pennsylvanian, Graham Formation, Texas, and also with ?Pleurophorella cuneata (Phillips) (Morris et al., 1991, p. 88, fig. 42), Lower Carboniferous (Viséan), Yorkshire.

non 1840 Sanguinolaria laevigata Goldfuss, p. 279, pl. 149, fig. 14; [gen. indet., nom. dub.; a partially exposed, unidentifiable shell; probably not a solemyid]; Devonian, Eifel.

p 1895 Janeia laevigata (Goldfuss); Beushausen, p. 294, pl. 26, fig. 2a-c [possible Pleurophorella; hinge and interior unknown]; Devonian, Daleiden, Germany; non pl. 26, fig. 8 [copy of Goldfuss' type, gen. indet.].

Pleurophorella? cf. tricostata (Portlock, 1843)

Remark. Different from Beushausen's other Janeia laevigata; compares with Sanguinolites striatogranulatus Hind, considered by Morris et al. (1991) as possibly synonymous with Pleurophorella tricostata (Portlock).

p 1895 Janeia laevigata (Goldfuss); Beushausen, p. 294, pl. 26, fig. 3a-b [Pc, Pr2; with buttresslike feature]; Middle Devonian, Gerolstein, Germany; non pl. 26, fig. 2a-c; Devonian Daleiden, Germany.

? 1900 Sanguinolites striatograunulatus Hind, $p$. 393-394, pl. 42, figs. 16-22; Lower Carboniferous, Isle of Man, Yorkshire, and Ireland.

? 1991 Pleuorphorella tricostata (Portlock); Morris et al., p. 87, fig. 38a-h; Lower Carboniferous, Isle of Man, Yorkshire, and Ireland.

Genus STUTCHBURIA Etheridge, 1900

Type species. By original designation, Orthonota? costata Morris, 1845; Permian, southeastern Australia.

Remarks. Needs further study. Logan's (1967) placement of Cardiomorpha modioliformis King in Stutchburia is uncertain. Although the subquadrate shell profile and coarse radial ribs of the type species are lacking, Logan (1967, p. 50) argued that Etheridge's original definition of Stutchburia was 
broadly defined to include forms with a modioloid outline and variable prosopon.

Stutchburia? cf. modioliformis (King, 1850) sp. inq.

Remark. Howse's (1857a, pl. 4, figs. 8, 9) simple drawing of Solemya abnormis Howse superficially compares with Stutchburia modioliformis (King, 1850), but hinge, ligament, and interior unknown.

1848 Solenimya abnormis Howse, p. 244 [description only; Pc, Pr0; prosopon with comarginal "waves"; anisomyarian; adductor muscles deeply impressed; hinge and ligament unknown; not a solemyid]; Upper Permian, Magnesian Limestone, Silksworth and Tunstall.

non 1850 Janeia biarmica (de Verneuil); King, p. 178 (non de Verneuil, 1845); [no figure; in error, King considered Solenomya abnormis of Howse to be a junior synonym of $\mathrm{J}$. biarmica (de Verneuil).

? p 1850 Cardiomorpha modioliformis King, p. 180, pl. 14, 20-22; non figs. 18, 19, 23; Upper Permian, "Shell-Limestone", Tunstall Hill, Ryehope Field-House-Farm and Humbleton Quarry, Durham, England.

1857a Solemya abnormis Howse; Howse, p. 309; pl. 4, figs. 8, 9 [figures to accompany 1848 description; Pc, PrO; modioloid profile, anisomyarian, not a solemyid]; Upper Permian, "Shell-Limestone", Silksworth, Durham, England.

1858 Solemya biarmica? de Verneuil; Howse (?Howse), p. 266, pl. 11, figs. 8, 9 [same specimen was shown by Howse (1857a) under the name of Solemya abnormis]; Upper Permian, "Shell Limestone", Silksworth, Durham, England.

? 1967 Stutchburia modioliformis (King); Logan, p. 51 , pl. 8, fig. 8a-e (= lectotype); [compares with both Solemya abnormis Howse and Cardiomorpha modioliformis King]; Upper Permian, Middle Magnesian Limestone, Tunstall Hill, Durham, England.

? p 1981 Stutchburia modioliformis (King); Muromtseva, p. 41, pl. 10, fig. 11?, non 12a [gen. et sp. indet.]; Permian, Novaya Zemlya.

? 1984 Stutchburia modioliformis (King); Muromtseva and Guskov, p. 85, pl. 5, pl. 5, figs. 2, 10, 11; pl. 24, fig. 9a-b [compares with Solemya abnormis Howse]; Upper Permian, Russian Platform, Urals and Pechora Basin.

\section{PROBLEMATICA (incertae sedis)}

Remarks. The following listings marked ?? are either generically indeterminate or misidentified, etc. See comments in brackets.

?? Solenomya phillipsiana King, 1850, p. 179, pl. 16, fig. 8. [nom. dub.; Howse $(1849$, p. 9) called it a "mere fiction" based allegedly on nonexistent material from the "Shell-Limestone"]; Humbledon Quarry, Durham, England.

non 1854 Solenomya phillipsiana King; Schauroth, p. 553, pl. 21, fig. 5 [Pc, Pr1; gen.indet.]; Upper Permian (lower Zechstein), Bucha, Germany.

non 1861 Solemya biarmica de Verneuil; Geinitz, p. 60, pl. 12, fig. 19a-c [gen. indet.; Schauroth's original specimen of $S$. phillipsiana was refigured but significantly altered and reassigned in error by Geinitz to S. biarmica]; Upper Permian (lower Zechstein), Bucha, Germany.

?? Solemya arcuata (Phillips); de Ryckholt, (1847) 1854 , p. 52 [no figure; not a solemyid; based solely on earlier studies of Phillips and King]; Lower Carboniferous, (Tournaisian) l'argile carbonifère, Tournai, Belgium.

? 1836 Sanguinolaria? arcuata Phillips (?Phillips) 1836, p. 209, pl. 5 , fig. 4 [possible mytilid, aff. Lithophaga Röding, 1798]; Harelaw, Northumberland, England.

non 1849 Sanguinolites arcuatus (Phillips); Brown, $p$. 219, pl. 90, fig. 16 [drawing after Phillips; possible mytilid, aff. Lithophaga].

non 1850 Edmondia arcuata (Phillips); King, p. 164 [no figure].

non 1899 Edmondia arcuata (Phillips); Hind, p. 310, pl. 35, fig. 2 [= Acharax?; solemyiform shell, expanded brevidorsal auricle; Bts?, PAe?, Pc, Pr0]; fig. 3 [like fig. 2 but with fine radial ornament; Pc, Pr1]; Carboniferous, Redesdale Ironstone series, Northumberland; non pl. 35, figs. 1, 4, 6-10; Hurlet Limestone, St. Monans, Fife, and Redesdale Ironstone, Northumberland.

non 1903 Edmondia? arcuata Cleland (?Cleland), 1903 , p. 44 , pl. 4, figs. 5-7 [= possible Edmondia but junior homonym of Edmondia arcuata (Phillips)]; Ordovician (Beekmantown), New York.

?? Solemya devonica de Ryckholt (1847) 1854, p. 51, pl. 16, figs. 16, 17; [gen. indet.; possible solemyid based on description, but fig. 16 is badly flawed, described by de Ryckolt himself, p. 51, as "plus inexacte"]; Devonian, Eifel.

1878 Solenomya devonica de Ryckholt; Bigsby, p. 76 [no figure]; Devonian, Eifel, Paffrath, Germany. 
?? Solemya parallela de Ryckholt, (1847) 1854, p. 51, pl. 11, figs. 11, 12. [non Solenomya parallela Beede and Rogers (1899); Pr0; parallel dorsal and ventral margins; beaks placed at extreme breviterminus; treated by Hind (1899, p. 318 ) as possible synonym of Edmondia sulcata Phillips, 1836; not a solemyid; possible pholadomyid, cf. Wilkingia Wilson, 1959]; Lower Carboniferous, (Tournaisian) Tournai, Belgium.

non 1885 Solemya parallela de Ryckholt; de Koninck, p. 121 , pl. 23 , figs. 35,36 [possible solemyid?, PrO, Ne?]; non figs. 37, 38 [= Edmondia, cf. arcuata (Phillips)]; Lower Carboniferous, (Tournaisian), calschiste de Tournai, Belgium.

?? Solemya (?) recurvata Swallow (?Swallow) 1858 , p. 208-209 [gen. indet.; description only; no figure; described as showing the remains of an external ligament; recurving gibbous shell, large beaks; comarginal growth laminae described; radii not indicated]; Upper Coal Measures, Clifton Park, Kansas.

1877 Solenomya recurvata Swallow; Miller, p. 204 [no figure].

1889 Solenomya recurvata Swallow; Miller, p. 512 [no figure].

1896 Solemya recurvata Swallow; Hind, p. 29 [no figure].

?? Solenomya monroensis Worthen, 1884, p. 13. [gen. indet.; description only; no figure; size small with comarginal growth lines; ligament, hinge and interior unknown]; Mississippian, St. Louis Limestone, Monroe Co., Illinois.

1889 Solenomya monroensis Worthen; Miller, $\mathrm{p}$. 512 [no figure].

1896 Solenomya monroensis Worthen; Hind, p. 52 [no figure].

1890 Solenomya monroensis Worthen; Worthen, p. 131 , pl. 18 , fig. 5,5 a [copy of 1884 description; figure 5 shows umbo too narrow and prominent for a solemyid; radii lacking; evenly spaced comarginal growth varices; oblique longiterminus with longidorsum slightly elevated; dorsum (Worthen's fig. 5a) shows no evidence of ligament; form suggestive of Edmondia].

?? Solenomya varsoviensis Worthen, 1884, p. 12 [no figure; description of the shell form and size; ligament, hinge, and interior unknown]; Mississippian, Keokuk Limestone, Warsaw, Illinois.

1889 Solenomya varsoviensis Worthen; Miller, $\mathrm{p}$. 512 [no figure].

? 1890 Solenomya varsoviensis Worthen; Worthen, p. 131 [copy of 1884 description], pl. 19, fig. 7 [not a solemyid; featureless; outline com- pares with Edmondia ovata Meek and Worthen, 1873]; non pl. 19, fig. 8, 8a [not a solemyid; smooth outer surface; posteriorly elongate and expanded; dorsal view shows no ligament; concave posterodorsal margin; possibly with large posterior gape; probable pholadomyid, cf. Chaenomya Meek, 1864; compares with Anelli et al., fig. 7A]; Mississippian, Keokuk Limestone, Warsaw, Illinois.

1896 Solenomya varsoviensis Worthen; Hind, 1896, p. 52 [no figure].

?? Solenomya? iowensis Worthen (?Worthen), 1884, p. 13 [no figure; size (small) and shell shape described; ornament, ligament and internal features unknown]; Mississippian, St. Louis Limestone, Pella, lowa.

1889 Solenomya iowensis Worthen; Miller, p. 512 [no figure].

1890 Solenomya? iowensis Worthen (?Worthen); Worthen, p. 132 [copy of 1884 description]; pl. 19, fig. 5, 5a [not a solemyid; possible kalenterid, cf. Pleurophorella? Girty, 1904; compares with Anelli et al., 2009, fig. 2H]; Mississippian, St. Louis Limestone, Pella, lowa.

1896 Solenomya? iowensis Worthen (?Worthen); Hind, p. 52 [no figure].

?? Solenomya subradiata Herrick, 1887 , p. 30 , pl. 3, fig. 8. [gen. indet.; possible solemyid? Shell thin, somewhat solemyiform with prosoponal radii, but umbos too prominent; protruding heel on breviterminus; hinge, ligament, and interior unknown]; Coal Measures, (Pennsylvanian), Flint Ridge, Ohio.

?? Solenomya? cuyahogensis Herrick (?Herrick), 1888, p. 115, pl.10, fig. 1 [gen. indet.; short valves, very small and conjoined; probably not a bivalve; possible conchostracan. Herrick thought it might be Edmondia]; Lower Mississippian, Waverly Group, Cuyahoga Falls, Ohio.

? 1895 Solenomya? cuyahogensis Herrick (?Herrick); Herrick, pl. 22, fig. 25 [gen. indet.; short valves, very small and conjoined - possible conchostracan]; Carboniferous, Cuyahoga Shale, Cuyahoga Falls, Ohio.

?? Janeia phaseolina (Goldfuss); Beushausen, 1895, p. 295 pl. 26, figs. 6, 7, 9 [a heterogeneous mix].

? 1840 Sanginolaria phaseolina Goldfuss, p. 279, pl. 159, fig. 15 [gen. et sp. indet; Pc, Pr1; elevated umbos, hinge, ligament and interior unknown]; Devonian, Eifel.

non 1855 Edmondia phaseolina (Goldfuss); M'Coy, 1855, p. 502. Lower Carboniferous limestone, Lowick, Northumberland; [= Edmondia lowickensis Hind, 1899, p. 296, pl. 33, figs. 1- 
4]; Carboniferous, Fourlaws Limestone, Coombs, Northumberland, etc.

? 1895 Janeia phaseolina (Goldfuss); Beushausen, pl. 26, fig. 9 [copy of Goldfuss's type; differs slightly, hinge, ligament and interior unknown; Pc; gen. et sp. indet.; possible edmondiid?].

? 1895 Janeia phaseolina (Goldfuss); Beushausen, p. 296, text-fig. 31 [differs from Goldfuss' type; hinge, ligament, and interior uniknown = Edmondia?]; Middle Devonian, Gerolstein, Germany.

? 1895 Janeia phaseolina (Goldfuss); Beushausen, pl. 26, fig. 6 [differs in form Goldfuss' type and from text-fig. 31; shell thick; Pc (strong), buttress lacking; hinge and ligament uknown = Edmondia?]; Devonian, Eifel.

? 1895 Janeia phaseolina (Goldfuss); Beushausen, pl. 26, fig. 7, [significantly differs from Beushausen's other examples of J. phaseolina; short, sulcate shell with tumid umbos; possible sanguinolitid, = Myofossa? Waterhouse]; Middle Devonian, Gerolstein, Germany.

?? Solenomya brevis Hind, 1907, p. 351, pl. 2, figs. 45, 47 [Pr0; gen.indet.; non-solemyid shell profile; hinge, ligament and interior unknown]; Carboniferous, Millstone Grit, Coatbridge, Dumbartonshire, Scotland.

?? Solenomya? sharonensis Morningstar (?Morningstar), 1922, p. 194, pl. 10, figs. 1, 2, [not a sole- myid; characters include small but prominent umbos, nasute longiterminus; straight/slightly declining hinge line; possible modiomorphoid, aff. Sphenotomorpha Williams and Breger, 1916]; Pennsylvanian, Scioto Co., Ohio.

?? Solenomya sp. McKee, 1938, pl. 15, fig. 4. [gen. indet; not a solemyid; PrO; ventrally embayed; alate; elevated subcentral umbos]; pl. 15, fig. 10 [gen. indet.; Kues and Lucas (1989, p. 171) called it Sanguinolites?]; Permian, ' $\beta$ ' member, Kaibab Formation, Grand Canyon, Arizona.

?? Solemya (Janeia) elliptica Zhang, 1977, p. 526, pl. 200, figs. 16, 17 [Pr2; possible solemyin, cf. Acharax?, but ligament and internal morphology not observed]; Permian, south-central (Hubei, Hunan), China.

?? Solemya (Janeia) minuta Zhang, 1977, p. 526, pl. 200, fig. 18 [Pr2; hinge, ligament not observed, possible solemyin?]; Permian, south-central (Lichuan, Hubei) China.

?? Solemya (Janeia) sp. Kues and Lucas, 1989, p. 171, fig. 3A-C [gen. indet.; poorly preserved]; Permian, San Andres Formation, Ojo Caliente, New Mexico.

?? Solemya (Jania) [sic] sp. Hoare, 2007, p. 65, fig. 3.20; [gen. indet.; broken shell with radiating ridges intersected by coarse comarginal discontinuities; probably not a solemyid]; Mississippian, Maxville Limestone, Ohio.

\section{REFERENCES}

Allen, J.A. and Hannah, F.J. 1986. A reclassification of the Recent genera of the subclass Protobranchia (Mollusca: Bivalvia). Journal of Conchology, 32:225-249.

Amano, K. and Kiel, S. 2011. Fossil Adulomya (Vesicomyidae, Bivalvia) from Japan. The Veliger, 51(2):76-90.

Amler, M.R.W. 1999. Synoptical classification of fossil and Recent Bivalvia. Geologica et Palaeontologica, 33:237-248.

Anelli, L.E., Rocha-Campos, A.C., Simões, M.G., and Peck, R.L. 2009. Pennsylvanian Heteroconchia (Mollusca, Bivalvia) from the Piauí Formation, Parnaíba Basin, Brazil. Revista Brasileira de Paleontologia, 12(2):93-112. https://doi.org/10.4072/rbp.2009.2.01

Bailey, J.B. 1983. Middle Devonian Bivalvia from the Solsville Member (Marcellus Formation) central New York State. Bulletin of the American Museum of Natural History, 174:196-325.

Bailey, J.B. 2009. Shell orientation terminology among the Bivalvia (Mollusca): problems and proposed solutions. Journal of Paleontology, 83:493-495. https://doi.org/10.1666/08-111.1

Bailey, J.B. 2011. Paleobiology, paleoecology, and systematics of Solemyidae (Mollusca: Bivalvia: Protobranchia) from the Mazon Creek Lagerstätte, Pennsylvanian of Illinois. Bulletins of American Paleontology, 382:1-72.

Bailey, J.B. 2016. "O Solemya..." Ligamental plesiomorphy and apomorphy in the AcharaxSolemya clade (Bivalvia: Solemyidae). Geological Society of America 2016 Annual Meeting, 25-28 September, Denver, Colorado. Geological Society of America Abstracts with Programs, 48(7):118-11. https://doi.org/10.1130/abs/2016AM-281610 
Bailey, J.B. and Prosh, E.C. 2016. Revisiting the Early Devonian reef knolls of Lowther Island, Nunavut Territory, Arctic Canada: A retrospective on the research of Eric C. Prosh. Geological Society of America, North-Central Section 50th Annual Meeting, 18-19, April 2016, University of Illinois at Urbana-Champaign. Geological Society of America Abstracts with Programs, 48(5):12-12. https://doi.org/10.1130/abs/2016NC-275422

Bailey, J.B. and Sroka, S.D. 1997. Chapter 8A. Bivalvia, with descriptions of two new species, p. 93-116. In Shabica, C.W. and Hay, A.A. (eds.), Richardson's Guide to the Fossil Fauna of Mazon Creek. Northeastern Illinois University, Chicago.

Baily, W.H. 1880. Palaeontological notes, p. 18-22. In Symes, R.G. and Kilroe, J.R., Explanatory memoir to accompany sheet 54 , and the south-west portion of 42 of the maps of the geological survey of Ireland, illustrating parts of the counties of Sligo and Mayo. Memoirs of the Geological Survey, Dublin.

Beede, J.W. 1900. Carboniferous invertebrates. Kansas University Geological Survey, 6(2):1187.

Beede, J.W. and Rogers, A.F. 1899. New and little known pelecypods from the coal measures. University of Kansas Quarterly, 8:131-134.

Bengtson, P. 1988. Open nomenclature. Palaeontology, 31(1):223-227.

Bernard, F.R. 1980. A new Solemya s. str. from the northeastern Pacific (Bivalvia: Cryptodonta). Venus, 39:17-23.

Beushausen, L. 1895. Die Lamellibranchiaten des rheinischen Devon mit Ausschluss der Aviculiden. Königlich Preussischen geologischen Landesanstalt, Neue Folge, 17:1-514.

Bieler, R., Carter, J.G., and Coan, E.V. 2010. Classification of bivalve families, p. 113-133. In Bouchet, P. and Rocroi, J.-P. (eds.), Nomenclator of bivalve families with a classification of bivalve families. Malacologia, 52(2):1-184. https://doi.org/10.4002/040.052.0201

Bieler, R., Mikkelsen, P.M., Collins, T.M., Glover, E.A., González, V.L., Graf, D.L., Harper, E.M., Healy, J., Kawauchi, G.Y., Sharma, P.P., Staubach, S., Strong, E.E., Taylor, J.D., Tëmkin, I., Zardus, J.D., Clark, S., Guzmán, A., Mclntyre, E., Sharp, P., and Giribet, G. 2014. Investigating the Bivalve Tree of Life - an exemplar-based approach combining molecular and novel morphological characters. Invertebrate Systematics, 28:32-115. https://doi.org/10.1071/IS13010

Bigsby, J.J. 1878. Thesaurus Devonico-Carboniferus. The Flora and Fauna of the Devonian and Carboniferous Periods. John Van Voorst, London.

Branson, C.C. 1930. Paleontology and stratigraphy of the Phosphoria Formation. Missouri University Studies, 5(2):1-99.

Brown, T. 1849. Illustrations of the Fossil Conchology of Great Britain and Ireland with Descriptions and Locations of the Species. Smith, Elder and Co., London.

Campbell, K.A., Nesbitt, E.A., and Bourgeois, J. 2006. Signatures of storms, oceanic floods and forearc tectonism in marine shelf strata of the Quinault Formation (Pliocene), Washington, United States. Sedimentology, 53:945-969. https://doi.org/10.1111/j.1365-3091.2006.00788.x

Carter, J.G. 1990. Chapter 10. Evolutionary significance of shell microstructure in the Palaeotaxodonta, Pteriomorphia and Isofilibranchia (Bivalvia Mollusca), p.135-296. In Carter, J.G. (ed.), Skeletal Biomineralization: Patterns, Processes and Evolutionary Trends. Van Nostrand Reinhold, New York.

Carter, J.G. 2001. Shell and ligament microstructure of selected Silurian and Recent palaeotaxodonts (Mollusca: Bivalvia). American Malacological Bulletin, 16(1):217-238.

Carter, J.G., Lawrence, D.R., and Sanders, H. 1990. Chapter 12. Shell microstructural data for the Bivalvia. Part 2. Orders Nuculoida and Solemyoida, p. 303-319. In Carter, J.G. (ed.), Skeletal Biomineralization: Patterns, Processes and Evolutionary Trends. Van Nostrand Reinhold, New York.

Carter, J.G., Campbell, D.C., and Campbell, M.R. 2000. Cladistic perspectives on early bivalve evolution, p. 47-97. In Harper, E.M., Taylor, J.D., and Crame, J.A. (eds.), The Evolutionary Biology of the Bivalvia. Geological Society (London), Special Publications, 177. https://doi.org/10.1144/GSL.SP.2000.177.01.04

Carter, J.G., Altaba, C.R., Anderson, L.C., Araujo, R., Biakov, A.S., Bogan, A.E., Campbell, D.C., Campbell, M., Jin-hua, C., Cope, J.C.W., Delvene, G., Dijkstra, H.H., Fang Zong-jie, Gardner, R.N., Gavrilova, V.A., Goncharova, I.A., Harries, P.J., Hartman, J.H., Hautmann, M., Hoeh, W.R., Hylleberg, J., Bao-yu, J., Johnston, P., Kirkendale, L., Kleemann, K., Koppka, J., Kř́ž, J., Machado, D., Malchus, N., Márquez-Aliaga, A., Masse, J-P., McRoberts, C.A., Middelfart, P.U., Mitchell, S., Nevesskaja, L.A., Özer, S., Pojeta, J. Jr., Polubotko, I.V., Pons, J.M., 
Popov, S., Sánchez, T., Sartori, A.F., Scott, R.W., Sey, I.I., Signorelli, J.H., Silantiev, V.V., Skelton, P.W., Steuber, T., Waterhouse, J.B., Wingard, G.L., and Yancey, T. 2011. A synoptical classification of the Bivalvia (Mollusca). Paleontological Contributions, 2011(4):147. https://doi.org/10.17161/pc.1808.8287

Carter, J.G., Harries, P.J., Malchus, N., Sartori, A.F., Anderson, L.C., Bieler, R., Bogan, A.E., Coan, E.V., Cope, J.C.W., Cragg, S.M., García-March, J.R., Hylleberg, J., Kelley, P., Kleemann, K., Kříž, J., McRoberts, C., Mikkelsen, P.M., Pojeta, J. Jr., Tëmkin, I., Yancey, T., and Zieritz, A. 2012. Illustrated glossary of the Bivalvia, Part N, Revised, Volume 1, Chapter 31. Treatise Online, 48: 1-209. https://doi.org/10.17161/to.v0i0.4322

Children, J.G. 1823. Lamarck's genera of shells (with plates), continued. Quarterly Journal of Science, Literature and the Arts, 14(28):298-322.

Chronic, H. 1952. Molluscan fauna from the Permian Kaibab Formation, Walnut Canyon, Arizona. Geological Society of America Bulletin, 16:95-166. https://doi.org/10.1130/0016-7606(1952)63[95:MFFTPK]2.0.CO;2

Ciriacks, K.W. 1963. Permian and Eotriassic bivalves of the Middle Rockies. Bulletin of the American Museum of Natural History, 125(1):1-100 + 16 pl.

Claypole, E.W. 1886. Report on some fossils from the lower Coal Measures near Wilkes-Barre, Luzerne County, Pennsylvania. Proceedings and Collections of the Wyoming Historical and Geological Society, 2:239-253.

Cleland, H.F. 1903. Further notes on calciferous (Beekmantown) Formation of the Mohawk Valley with descriptions of new species. Bulletins of American Paleontology, 4(18):1-51.

Coan, E.V., Scott, P.V., and Bernard, F.R. 2000. Bivalve Seashells of Western North America. Santa Barbara Museum of Natural History, Santa Barbara, California.

Combosch, D.J., Collins, T.M., Glover, E.A., Graf, D.L., Harper, E.M., Healy, J.M., Kawauchi, G.Y., Lemer, S., Mclntyre, E., Strong, E.E., Taylor, J.D., Zardus, J.D., Mikkelsen, P.M., Giribet, G., and Bieler, R. 2016. A family-level Tree of Life for bivalves based on a Sangersequencing approach. Molecular Phylogenetics and Evolution, 107:191-208. https://doi.org/10.1016/j.ympev.2016.11.003

Conrad, T.A. 1842. Observations on the Silurian and Devonian systems of the United States with descriptions of new organic remains. Journal of the Academy of Natural Sciences of Philadelphia, 8(2):228-280.

Conrad, T.A. 1870. Descriptions of new fossil Mollusca, principally Cretaceous. American Journal of Conchology, 6(2):96-103.

Cope, J.C.W. 1995. The early evolution of the Bivalvia, p. 361-370. In Taylor, J.D. (ed.), Origin and Evolutionary Radiation of the Mollusca. Oxford University Press, Oxford. [Dated 1996]

Cope, J.C.W. 1996. Early Ordovician (Arenig) bivalves from the Llangynog inlier, South Wales. Palaeontology, 39:979-1025.

Cope, J.C.W. 1997. Early phylogeny of the Class Bivalvia. Palaeontology, 40(3):713-746.

Cope, J.C.W. 2000. A new look at early bivalve phylogeny, p. 81-95. In Harper, E.M., Taylor, J.D., and Crame, J.A. (eds.), The Evolutionary Biology of the Bivalvia. Geological Society, London, Special Publications, 177. https://doi.org/10.1144/gsl.sp.2000.177.01.05

Cope, J.C.W. 2002. Diversification and biogeography of bivalves during the Ordovician period, p. 25-52. In Crame, J.A. and Owen, A.W. (eds.), Palaeobiogeography and Biodiversity Change: The Ordovician and Mesozoic-Cenozoic Radiations. Geological Society of London Special Publications, 194. https://doi.org/10.1144/gsl.sp.2002.194.01.04

Cox, E.T. 1857. Palaeontological report of Coal Measure Mollusca, p. 557-576. In Lyon, S.S., Cox, E.T., and Lesquereux, L. (eds.), The Palaeontological Report of S. S. Lyon, E.T. Cox, and Leo. Lesquereux as Prepared for the Geologic Report of Kentucky and Published in Volume 3. Kentucky Geological Survey, Frankfurt, Kentucky.

Cox, L.R. 1969. Superfamily Solemyacea, p. N241-N243. In Moore, R.C. and Teichert, C. (eds.), Treatise on Invertebrate Paleontology, Part N, Mollusca 6, Bivalvia 2. Geological Society of America and University of Kansas Press, Boulder, Colorado, and Lawrence, Kansas.

Cuvier, G. 1836. Le Règne Animal Distribue D'Après son Organisation, pour servier de base a L'Histore Naturelle Des Animaux. Les Mollusques, Atlas. Paris, Fortin, Masson et Cie.

Dall, W.H. 1889. On the hinge of pelecypods and its development, with an attempt toward a better subdivision of the group. American Journal of Science, 38:445-462.

https://doi.org/10.2475/ajs.s3-38.228.445 
Dall, W.H. 1891. Scientific results of explorations by the U. S. Fish Commission steamer Albatross. No. XX.-On some new or interesting West American shells obtained from the dredgings of the U.S. Fish Commission steamer Albatross in 1888, and from other sources. Proceedings of the United States National Museum, 14:173-191. https://doi.org/10.5479/si.00963801.14-849.173

Dall, W.H. 1908. A revision of the Solenomyacidae. The Nautilus, 22:1-2.

Dechaseaux, C. 1952. Classe des Lamellibranches, p. 220-246, 261-364. In Piveteau, J. (ed.), Traité de Paléontologie, 2. Masson et Cie, Paris.

Dell, R.K. 1995. New species and records of deep-water Mollusca from off New Zealand. Tuhinga: Records of the Museum of New Zealand Te Papa Tongarewa, 2:1-26.

de Férussac, A.E. 1821-1822. Tableaux Systématiques des Animaux Mollusques. ArthusBertrand, Paris; J.B. Sowerby, London.

de Koninck, L.G. 1841-1844. Description des animaux fossiles qui se trouvent dans le terrain carbonifère de Belgique. Dessain, Liège, Belgium.

de Koninck, L.G. 1885. Faune du calcaire carbonifère de la Belgique, Cinquième Partie, Lamellibranches. Annales du Musée Royal d'Histoire Naturelle de Belgique, 11:1-285.

de Ryckholt, P. 1851-1862. Mélanges Paléontologiques. 1851. Parts 1-3, Mémoires Couronnés et Mémoires des Savants Étrangers de l'Académie Royale des Sciences, des Lettres et des Beaux-Arts de Belgique, 24. M. Hayez, Bruxelles.

de Verneuil, P.E.P. 1845. Mollusques, p. 37-376. In Murchison, R.I., de Verneuil, E., and de Keyserling, A., Géologie de la Russie D’Europe et Des Montagnes De L'Oural, Vol. 2, no. 3, Paléontologie. John Murray, Albemarle Street, London, and Bertrand, Rue Saint-André-desArts, no. 38, Paris.

Dickins, J.M. 1963. Permian pelecypods and gastropods from western Australia. Commonwealth of Australia, Department of National Development, Bureau of Mineral Resources, Geology and Geophysics, Bulletin, 63:1-203.

Dickins, J.M. 1999. Mid-Permian (Kubergandian-Murgabian) bivalves from the Khuff Formation, Oman: Implications for world events and correlations. Rivista Italiana di Paleontologia e Stratigrafia, 105(1):23-36. https://doi.org/10.13130/2039-4942/5364

Diener, C. 1897. The Permian fossils of the Productus shales of Kumaon and Gurhwal. Palaeontologica Indica. Memoirs of the Geological Survey of India, series 15, Himalayan Fossils, series 1(4):1-54.

Duff, K.L. 1978. Bivalvia from the English Lower Oxford Clay (Middle Jurassic). The Palaeontographical Society [London], 132(553):1-137 + 13 pl.

Eichwald, E. 1859-1860. Lethaea Rossica ou Paléontologie de la Russie, 1. E. Schweizerbart, Stuttgart.

Etheridge, R. Jr. 1900. Little known and undescribed Permo-Carboniferous Pelecypoda in the Australian Museum. Records of the Australian Museum, 3:178-187. https://doi.org/10.3853/j.0067-1975.3.1900.1168

Geinitz, H.B. 1848. Die Versteinerungen des deutschen Zechsteingebirges, p. 1-26. In Geinitz, H.B. and Gutbier, A. (eds.), Die Versteinerungen des Zechsteinsgebirge und Rothliegenden, oder des permischen Systemes in Sachsen, Heft. 1. Arnoldische Buchhandlung, Dresden and Leipzig.

Geinitz, H.B. 1861. Zechsteinformation und das Rothliegende, Heft 1. Die Animalischen Ueberreste der Dyas. Verlag von Wilhelm Engelmann, Leipzig.

Geinitz, H.B. 1866. Carbonformation und Dyas in Nebraska. E. Blochmann, Dresden.

Giribet, G. 2008. 6. Bivalvia, p. 105-135. In Ponder, W.F. and Lindberg, D.R. (eds.), Phylogeny and Evolution of the Mollusca. University of California Press, Berkeley. https://doi.org/10.1525/california/9780520250925.003.0006

Giribet, G. and Distel, D.L. 2003. Bivalve phylogeny and molecular data, p. 45-90. In Lydeard, C. and Lindberg, D.R. (eds.), Molecular Systematics and Phylogeography of Mollusks. Smithsonian Books, Washington D.C.

Girty, G.H. 1904. New molluscan genera from the Carboniferous. Proceedings of the United States National Museum, 27(1372):721-736. https://doi.org/10.5479/si.00963801.27-1372.721

Goldfuss, G.A. 1833-1840. Petrefacta Germaniae, 2. Arnz and Company, Düsseldorf, Germany.

Gray, J.E. 1840. Synopsis of the Contents of the British Museum, 42nd edition. C. Woodfall and Son, London. 
Gray, J.E. 1847. A list of the genera of Recent Mollusca, their synonyma and types. Zoological Society of London, Proceedings, 15:129-219.

Grobben, C. 1894. Zur Kenntniss der Morphologie, der Verwandtschaftsverhältnisse und des Systems der Mollusken. Kaiserliche Akademie der Wissenschaften (MathematischNaturwissenschaftlichen Classe), Sitzungsberichte, 103(1):61-86.

Hajkr, O., Lukasová, A., Růžička, B., and Řehoř, F. 1978. Janacekia gen. nov. (Bivalvia) aus dem Karbon. Freiberger Forschungshefte, C, Geowissenschaften-Paläontologie, 325:1-124 + 49 pl.

Hall, J. 1847. Palaeontology of New York. Volume 1. Containing descriptions of organic remains of the lower division of the New-York System (equivalent to the Lower Silurian rocks of Europe). Natural History of New York. Albany, New York.

Hall, J. 1858a. Descriptions of new species of fossils from the Carboniferous limestones of Indiana and Illinois. Transactions of the Albany (New York) Institute, 4(1):1-36.

Hall, J. 1858b. Palaeontology of lowa. Report of the Geological Survey of the State of lowa, $1(2): 473-724$.

Hall, J. 1883. Lamellibranchiata, plates and explanations. Natural History of New York, Palaeontology, 5(1):1-268 + 92 pl.

Hall, J. 1885. Lamellibranchiata II, descriptions and figures of the Dimyaria of the upper Helderberg, Hamilton, Portage and Chemung groups. New York State Geological Survey, Paleontology (Natural History of New York), 5(1):269-561.

Hall, J. (and Whitfield, R.P.) 1869-1870. Preliminary notice of the lamellibranchiate shells of the Upper Helderberg, Hamilton, and Chemung groups, with others from the Waverly sandstones, pt. 2. New York State Museum, Albany.

Hall, J. and Whitfield, R.P. 1872. Descriptions of new species of fossils, from the vicinity of Louisville, Kentucky, and the Falls of the Ohio; from the collection of Dr. James Knapp, of Louisville. Annual Report of the Regents of the University of the State of New York, 24:181200.

Hall, J. and Whitfield, R.P. 1875. Annual Report on the New York State Museum, 27, pl. 11. [no text]

Herrick, C.L. 1887. A sketch of the geological history of Licking County accompanying an illustrated catalogue of Carboniferous fossils from Flint Ridge, Ohio. Bulletin of the Denison University, 2(1):5-70.

Herrick, C.L. 1888. Geology of Licking County, O(hio). Bulletin of the Denison University, 4(1):97123.

Herrick, C.L. 1895. Observations on the so-called Waverly Group of Ohio. Report of the Geological Survey of Ohio, 7:495-515.

Hind, W. 1896-1901. A Monograph of the British Carboniferous Lamellibranchiata, vol. 2, pt.1. The Palaeontographical Society, London. https://doi.org/10.1080/02693445.1901.12035496

Hind, W. 1907. On the lamellibranch and gasteropod [sic] fauna found in the Millstone Grit of Scotland. Transactions of the Royal Society of Edinburgh, 46(2):331-360. https://doi.org/10.1017/S0080456800002799

Hoare, R.D. 1961. Desmoinesian Brachiopoda and Mollusca from southwest Missouri. University of Missouri Studies, 36:1-262.

Hoare, R.D. 2007. Bivalve mollusks from the Maxville Limestone (Mississippian) of Ohio. Ohio Journal of Science, 107(4):63-75.

Hoare, R.D., Sturgeon, M.T., and Kindt, E.A. 1979. Pennsylvanian marine Bivalvia and Rostroconchia of Ohio. Ohio Division of Geological Survey Bulletin, 67:1-77 + 18 pl.

Howse, R. 1848. A catalogue of the fossils of the Permian System of the counties of Northumberland and Durham. Transactions of the Tyneside Naturalists' Field Club, 1:219264.

Howse, R. 1857a. Notes on the Permian System of Northumberland and Durham; being a supplement to the Catalogue of Fossils of the Permian System of these Counties. Annals and Magazine of Natural History, series 2, 19(109):33-53; (112):304-312; (114):463-473. https://doi.org/10.1080/00222935708697690; https://doi.org/10.1080/00222935708693931 ; https://doi.org/10.1080/00222935708693968

Howse, R. 1857b. Note on the right of priority of a Catalogue of Permian Fossils, published by the Tyneside Naturalists' Field Club in Newcastle on Thursday, August 17th, 1848. South Shields, Philipson and Hare, Tyne Street. 
Howse, R. 1858. Notes on the Permian System of Northumberland and Durham; being a supplement to the Catalogue of Fossils of the Permian System of these Counties. Transactions of the Tyneside Naturalists' Field Club, 3:235-294.

Hryniewicz, K., Little, C.T.S., and Nakrem, H.A. 2014. Bivalves from the latest Jurassic-earliest Cretaceous hydrocarbon seep carbonates from central Spitzbergen, Svalbard. Zootaxa, 3859(1):1-66. https://doi.org/10.11646/zootaxa.3859.1.1

Hryniewicz, K., Jakubowicz, M., Belka, Z., Dopieralska, J., and Kaim, A. 2017. New bivalves from a Middle Devonian methane seep in Morocco: the oldest record of repetitive shell morphologies among some seep bivalve molluscs. Journal of Systematic Paleontology, 15(1):19-41. https://doi.org/10.1080/14772019.2015.1136900

Imhoff, J.F., Sahling, H., Süling, J., and Kath, T. 2003. 16s rDNA-based phylogeny of sulphuroxidising bacterial endosymbionts in marine bivalves from cold-seep habitats. Marine Ecology Progress Series, 249:39-51. https://doi.org/10.3354/meps249039

Kamenev, G.M. 2009. North Pacific species of the genus Solemya Lamarck, 1818 (Bivalvia: Solemyidae), with notes on Acharax johnsoni (Dall, 1891). Malacologia, 51:233-261. https://doi.org/10.4002/040.051.0202

Keyes, C.R. 1888. On the fauna of the Lower Coal Measures of Central lowa. Proceedings of the Academy of Natural Sciences of Philadelphia, 40:222-246.

Kiel, S. 2010. The fossil record of vent and seep molluscs, p. 255-277. In Kiel, S. (ed.), The Vent and Seep Biota. Aspects from Microbes to Ecosystems. Topics in Geobiology, 33. Springer, Dordrecht, Heidelberg, London and New York. https://doi.org/10.1007/978-90-481-9572-5_8

Kindle, E.M. 1901. The Devonian fossils and stratigraphy of Indiana. Indiana Department of Geology and Natural Resources Annual Report, 25:529-775.

King, W. 1848. A Catalogue of the Organic Remains of the Permien [sic] Rocks of Northumberland and Durham. Newcastle-upon-Tyne. [Printed and published by the author]

King, W. 1850. A monograph of the Permian fossils of England. The Palaeontological Society, London.

Kłapciński, J. and Karwowski, L. 1978. The Zechstein Fauna in the northern part of the ForeSudetic Monocline. Geologia Sudetica, 3(2):67-80.

Krainer, K., Lucas, S.G., and Kues, B.S. 2003. Upper Pennsylvanian strata in the Zuni Mountains, west-central New Mexico, p. 219-229. In Lucas, S.G., Semken, S.C., Berglof, W.R., and Ulmer-Scholle, D.S. (eds.), Geology of the Zuni Pleateau. New Mexico Geological Society Guidebook, 54th Annual Field Conference.

Kues, B.S. 1983. Cephalopod aptychi from Los Moyos Limestone, Madera Group (Middle Pennsylvanian), near Albuquerque, New Mexico. New Mexico Geology, 5(4):78-80.

Kues, B.S. 1992. A Late Pennsylvanian restricted-marine fauna from the Kinney Quarry, Manzanita Mountains, New Mexico. New Mexico Bureau of Mines and Mineral Resources Bulletin, 138:87-97.

Kues, B.S. and Lucas, S.G. 1989. Stratigraphy and paleontology of the San Andres Formation (Permian, Leonardian) outlier, Zuni Indian Reservation, New Mexico, p. 167-176. In Anderson, O.J., Lucas, S.G., Love, D.W., and Cather, S.M. (eds.), Southeastern Colorado Plateau. New Mexico Geological Society, 40th Annual Fall Field Conference Guidebook.

Kues, B.S., Giles, K.A., Mack, G.H., and Lawton, T.F. 2002. A Late Pennsylvanian outer shelf marine fauna from a highstand systems tract, Derry Hills, south-central New Mexico. New Mexico Geology, 24:121-130.

Kuroda, T. 1931. Molluscan fossils, p. 1-90. In Honma, F. (ed.), Shinano Chûbu Chishitu-Shi (Geologic Records of Central Shinano), Part 4. Kokon Shoin, Tokyo. [In Japanese]

Lamarck, J.B. 1799. Prodrome d'une nouvelle classification des coquilles, comprenant une rédaction appropriée des caractéres génériques, et l'établissement d'un grand nombre de genres nouveaux. Mémoires de la Société d'Histoire Naturelle de Paris, 1:63-91.

Lamarck, J.B. 1818. Histoire Naturelle des Animaux Sans Vertèbres, 5. A. Lanoe, Paris.

Leckenby, J. 1859. On the Kelloway Rock of the Yorkshire Coast. Quarterly Journal of the Geological Society of London,15:4-15. https://doi.org/10.1144/GSL.JGS.1859.015.01-02.07

Lesley, J.P. 1890. A dictionary of the fossils of Pennsylvania and neighboring states. Pennsylvania Geological Survey Report, Pt. 4, 1889, 3:915-1283.

Liljedahl, L. 1984a. Silurian silicified bivalves from Gotland. Sveriges Geologiska Undersökning C, 804:1-82.

Liljedahl, L. 1984b. Janeia silurica, a link between nuculoids and solemyoids (Bivalvia). Palaeontology, 27:694-698. 
Liljedahl, L. 1991. Contrasting feeding strategies in bivalves from the Silurian of Gotland. Palaeontology, 34(1):219-235.

Liljedahl, L. 1994. Silurian nuculoid and modiomorphid bivalves from Sweden. Fossils and Strata, 33:1-89. https://doi.org/10.1111/j.1502-3931.1993.tb01539.x

Logan, A. 1967. The Permian Bivalvia of Northern England. Palaeontographical Society Monographs, 121(518):1-72.

McAlester, A.L. 1968. Type species of Paleozoic nuculoid genera. Geological Society of America Memoir, 105:1-143. https://doi.org/10.1130/MEM105-p1

M'Coy, F. 1844. A Synopsis of the Characters of the Carboniferous Limestone Fossils of Ireland. M.H. Gill, University of Dublin Press, Dublin.

M'Coy, F. 1855. Description of the British Palaeozoic Fossils in the Geological Museum of the University of Cambridge. John W. Parker and Son, London.

McKee, E.D. 1938. The environment and history of the Toroweap and Kaibab formations of northern Arizona and southern Utah. Carnegie Institute of Washington Publication, 492:1268.

Marwick, J. 1953. Divisions and faunas of the Hokonui System (Triassic and Jurassic). New Zealand Geological Survey Paleontological Bulletin, 21:1-141.

Matthews, S.C. 1973. Notes on open nomenclature and synonymy lists. Palaeontology, 16(4):713-719.

Maxwell, P.A. 1988. Comments on "A Reclassification of the Recent genera of the Subclass Protobranchia (Mollusca: Bivalvia)" by Allen, J.A. and Hannah, F.J. (1986). Journal of Conchology, 33:85-96.

Mayer, M.C. 1861. Description de Coquilles fossiles des terrains tertiaires supérieurs. Journal de Conchyliologie, 3e série, 9:358-373.

Mayr, E. and Ashlock, P.D. 1991. Principles of Systematic Zoology, 2nd ed. McGraw-Hill, New York.

Meek, F.B. 1864. Check list of the invertebrate fossils of North America. Cretaceous and Jurassic. Smithsonian Miscellaneous Collection, 177:1-40.

Meek, F.B. 1871. New species of invertebrate fossils from the Carboniferous and Devonian rocks of Ohio. Proceedings of the Academy of Natural Sciences of Philadelphia, 23(1):57-88.

Meek, F.B. 1872. Report on the paleontology of Eastern Nebraska with some remarks on the Carboniferous rocks of that district, p. 83-245. In Hayden, F.V. (ed.), Final Report of the United States Geological Survey of Nebraska and Portions of the Adjacent Territories. Government Printing Office, Washington. https://doi.org/10.3133/70039703

Meek, F.B. 1873. Descriptions of invertebrate fossils of the Silurian and Devonian Systems. Report of the Geological Survey of Ohio, 1(2):1-243.

Meek, F.B. 1874. Notes on some of the fossils figured in the recently-issued fifth volume of the Illinois State Geological Report. American Journal of Science, 3:580-584. https://doi.org/10.2475/ajs.s3-7.42.580

Meek, F.B. 1875. A report on some of the invertebrate fossils of the Waverly Group and Coal Measures of Ohio. Report of the Geological Survey of Ohio, 2(2):269-347.

Meek, F.B. 1876. A report on the invertebrate Cretaceous and Tertiary fossils of the upper Missouri country. Report of the United States Geological Survey of the Territories, 9:1-629. https://doi.org/10.3133/70038980

Meek, F.B. and Worthen, A.H. 1860. Descriptions of new Carboniferous fossils from Illinois and other western states. Proceedings of the Academy of Natural Sciences of Philadelphia, 2(12):447-472.

Meek, F.B. and Worthen, A.H. 1866. Descriptions of invertebrates from the Carboniferous System. Geological Survey of Illinois, 2:145-423.

Meek, F.B. and Worthen, A.H. 1870. Descriptions of new species and genera of fossils from the Palaeozoic rocks of the western states. Proceedings of the Academy of Natural Sciences of Philadelphia, 22:22-45.

Meek, F.B. and Worthen, A.H. 1873. Fossils from the Coal Measures. Illinois Geological Survey, Volume 5, Geology and Palaeontology, Part 2, Descriptions of Invertebrates from the Carboniferous System, p. 560-619.

Ménégaux, A. 1889. Sur la branchie des lamellibranches et sur sa comparaison avec celle des Scutibranches. Société Philomatique de Paris, Bulletin (series 8), 1(1):137-144.

Miller, S.A. 1877. The American Paleozoic Fossils. Cincinnati, Ohio. [published by the author] 
Miller, S.A. 1889. Geology and Palaeontology for the Use of Amateurs, Students, and Scientists. Cincinnati, Ohio. [published by the author]

Morningstar, H. 1922. Pottsville Fauna of Ohio. Geological Survey of Ohio Bulletin, 25:1-312.

Morris, J. 1845. Descriptions of fossils, p. 270-291. In Strzelcki, P.E. (ed.), Physical Description of New South Wales and Van Dieman's Land. Longman, London.

Morris, N.J., Dickins, J.M., and Astafieva-Urbaitis, K. 1991. Upper Palaeozoic anomalodesmatan Bivalvia. Bulletin of the British Museum of Natural History (Geology), 47(1):51-100.

Muromtseva, V.A. 1981. Bivalve Mollusks, p. 26-51. In Kalashnikov, V.A., Kolod, N.A., Makarov, K.K., Mohn, V.A., Muromtseva, V.A., Sosipatrova, G.P., Ustritskiy, V.I., Felfilova, L.A., and Chernyak, G.Y. (eds.), Permian Deposits of Novaya Zemlya. Akademia Nauka, Leningrad. [In Russian]

Muromtseva, V.A. and Guskov, V.A. 1984. Permian Marine Deposits and Bivalve Molluscs of the Soviet Arctic. Ministry of Geology, USSR, Leningrad. [In Russian]

Netschajew, A. 1894. Die Fauna der permischen Ablagerungen des östlichen Theils des europäischen Russlands. Transactions of the Society of Naturalists, Kazan Imperial University, 27(4):1-503. [title in German; text in Russian]

Nettleroth, H. 1889. Kentucky fossil shells, a monograph of the fossil shells of the Silurian and Devonian rocks of Kentucky. Kentucky Geological Survey, Frankfurt, Kentucky.

Neulinger, S.C., Sahling, H., Sülling, J., and Imhoff, J F. 2006. Presence of two phylogenetically distinct groups in the deep-sea mussel Acharax (Mollusca: Bivalvia: Solemyidae). Marine Ecology Progress Series, 312:161-168. https://doi.org/10.3354/meps312161

Nevesskaja, L.A. 2009. Principles of systematics and the system of bivalves. Paleontologicheskii Zhurnal, 43(1):1-11. https://doi.org/10.1134/S0031030109010018

Nevesskaja, L.A., Popov, S.V., Goncharova, I.A., Guzhov, A.V., Janin, B.T., Polubotko, I.V., Biakov, A.S., and Gavrilova, V.A. 2013. Phanerozoic Bivalvia of Russia and surrounding countries. Transactions of the Paleontological Institute, 294:1-524. [In Russian]

Newell, N.D. 1957. Notes on certain primitive heterodont pelecypods. American Museum Novitates, 1857:1-14.

Oliver, G., Rodrigues, C.F., and Cunha, M.R. 2011. Chemosymbiotic bivalves from the mud volcanoes of Cadiz, NE Atlantic, with descriptions of new species of Solemyidae, Lucinidae and Vesicomyidae. ZooKeys, 113:1-38. https://doi.org/10.3897/zookeys.113.1402

Peck, R.L., Bailey, J.B., Heck, R.J., and Scaiff, N.T. 2009. X-ray CT scan as an aid to identification of a new bivalve species from the Mississippian Bluefield Formation, southeastern West Virginia. Journal of Paleontology, 83(6):954-961. https://doi.org/10.1666/09-100.1

Pelseneer, P. 1889. Sur la classification phylogénétique des pélécypodes. Bulletin Scientifique de la France et de la Belgique, 20:27-52.

Phillips, J. 1836. Illustrations of the Geology of Yorkshire, or a Description of the Strata and Organic Remains: Accompanied by a Geologic Map, Sections, and Diagrams and Figures of Fossils, Part 2, the Mountain Limestone District. John Murray, London.

Pojeta, J., Jr. 1988. The origin and Paleozoic diversification of solemyoid pelecypods. New Mexico Bureau of Mines and Mineral Resources Memoir, 44:201-271.

Pojeta, J., Jr. and Runnegar, B. 1985. The early evolution of diasome molluscs, p. 295-336. In Trueman, E.R. and Clarke, M.R. (eds.), The Mollusca vol. 10, Evolution. Academic Press, Orlando. https://doi.org/10.1016/B978-0-12-751410-9.50015-0

Poli, G.S. 1791-1795. Testacea Utriusque Siciliae Eorumque Historia et Anatome Aeneis Illustrata a losepho Xaverio Poli. Bodoni, Parma.

Portlock, J.E. 1843. Report on the geology of the County of Londonderry and of parts of Tyrone and Fermanagh. Milliken, Hodges and Smith, Dublin.

Prosh, E.C. 1988. A Lower Devonian Reef Sequence and Fauna, Disappointment Bay Formation, Canadian Arctic Islands. Unpublished Ph.D. dissertation, University of Western Ontario, London, Canada.

Quenstedt, W. 1930. Die Anpassung an die grabende Lebenweise in der Geschichte der Solenomyiden und Nuculaceen. Geologische und Paläontologische Abhandlungen, Neue Folge, 18(1):1-119.

Röding, P.F. 1798. Museum Boltenianum sive Catalogus cimeliorum e tribus regnis naturae quae olim collegerat Joachim Friedrich Bolten, M.D. p.d., Pars Secunda. Typis Johan Christi Trapii, Hamburg. 
Ros, S., De Renzi, M., Damborenea, S., and Márquez-Aliaga, A. 2012. Part N, Revised, Volume 1, Chapter 25: Early Triassic-Early Jurassic bivalve diversity dynamics. Treatise Online, 39:119. https://doi.org/10.17161/to.v0i0.4271

Ros-Franch, S., Márquez-Aliaga, A., and Dambonenea, S.E. 2014. Comprehensive database on Induan (Lower Triassic) to Sinemurian (Lower Jurassic) marine bivalve genera and their paleobiogeographic record. Paleontological Contributions, 8:1-219. https://doi.org/10.17161/PC.1808.13433

Rosenberg, G. and Petit, R.E. 1987. Ryckholt's Mélanges Paléontologiques, 1851-1862, with a new name for Tudicula H. and A. Adams, non Ryckholt. Proceedings of the Academy of Natural Sciences of Philadelphia, 139:53-64.

Růžička, B. and Řehoř, F. 1978. Janacekiidae Růžička and Řehoř fam. nov., p. 37-78. In Hajkr, O., Lukasová, A., Růžička, B., and Řehoř, F. (eds.), Janacekia gen. nov. (Bivalvia) aus dem Karbon. Freiberger Forschungshefte, series C, Geowissenschaften-Paläontologie, 325. TU Bergakademie Freiberg, Freiberg.

Say, T. 1822. An account of some of the marine shells of the United States. Journal of the Academy of Natural Sciences of Philadelphia, 2(2):221-325.

Scarlato, O.A. and Starobogatov, Y.I. 1979. Osnovnye Cherty Evoluyutsii i sistema Klassa Bivalvia Morfologiya, Sistematika i Filogeniya Mollyuskov. Trudy Zoologicheskogo Instituta, Akademiya Nauk SSSR, 80:5-38. [In Russian] English edited translation, by Boss, K.J. and Jacobson, M.K., 1985. Museum of Comparative Zoology, Department of Mollusks Special Occasion Publication, 5.

Schenck, H.G. 1934. Classification of nuculid pelecypods. Bulletin du Musée royal d'Histoire naturelle de Belgique, 10(20):1-78.

Seilacher, A. 1990. Aberrations in bivalve evolution related to photo- and chemosymbiosis. Historical Biology, 3:289-311. https://doi.org/10.1080/08912969009386528

Sharma, P., Zardus, E., Boyle, E., González, V., Jennings, R., Mclntyre, E., Wheeler, W., Etter, R., and Giribet, G. 2013. Into the deep: a phylogenetic approach to the bivalve subclass Protobranchia. Molecular Genetics and Evolution, 69:188-204. https://doi.org/10.1016/j.ympev.2013.05.018

Shimer, H.W. and Shrock, R.R. 1944. Index Fossils of North America. John Wiley and Sons, New York.

Smith, E.A. 1874. Mollusca, p. 1-7. In Richardson, J. and Gray, J.E. (eds.), The Zoology of the Voyage of the H. M. S. Erebus and Terror: Under the Command of Captain Sir James Clark Ross, R.N., F.R.S., During the Years 1839 to 1843, Volume 2. E. W. Janson, London.

Swallow, G.C. 1858. Solemya (?) recurvata Swallow, p. 208-209. In Shumard, B.F. and Swallow, G.C. (eds.), Descriptions of new fossils from the Coal Measures of Missouri and Kansas. Transactions of the Academy of Science of St. Louis, 1:198-227.

Stanley, S.M. 1970. Relation of shell form to life habits of the Bivalvia (Mollusca). Geological Society of America Memoir, 125:1-296. https://doi.org/10.1130/MEM125-p1

Stanley, S.M. and Yang, X. 1987. Approximate evolutionary stasis for bivalve morphology over millions of years: A multivariate, multilineage study. Paleobiology, 13(2):113-139. https://doi.org/10.1017/S009483730000868X

Sterren, A.F. and Cisterna, G.A. 2010. Bivalves and brachiopods in the Carboniferous-Early Permian of Argentine Precordillera: Diversification and faunal turnover in Southwestern Gondwana. Geologica Acta, 8(4):501-517. https://doi.org/10.1344/105.000001585

Swallow, G.C. and Hawn, F. 1858 [1860]. The rocks of Kansas. Transactions of the Academy of Science of St. Louis, 1:173-197.

Taviani, M., Angeletti, L., and Ceregato, A. 2011. Chemosynthetic bivalves of the family Solemyidae (Bivalvia, Protobranchia) in the Neogene of the Mediterranean Basin. Journal of Paleontology, 85(6):1067-1076. https://doi.org/10.1666/10-119.1

Taylor, J.D., Glover, E.A., and Williams, S.T. 2008. Ancient chemosynthetic bivalves: systematics of Solemyidae from eastern and southern Australia (Mollusca: Bivalvia), p. 75-104. In Davie, P.J.F. and Phillips, J.A. (eds.), Proceedings of the Thirteenth International Marine Biological Workshop. The Marine Fauna and Flora of Moreton Bay, Queensland. Memoirs of the Queensland Museum - Nature, 54(1).

Ulrich, E.O. 1894. The Lower Silurian Lamellibranchiata of Minnesota. Final Report of the Minnesota Geological and Natural History Survey, 3:475-628.

Vokes, H.E. 1954. Some primitive fossil pelecypods and their possible significance. Journal of the Washington Academy of Science, 44:233-236. 
von Schauroth, K. 1854. Ein Beitrag zur Palaeontologie des deutschen Zechsteingebirges. Zeitschrift der Deutschen geologischen Gesellschaft, 6:553-577.

von Zittel, K. 1913. Textbook of Paleontology, Charles R. Eastman, ed. Volume 1. MacMillan and Co., Ltd., St. Martin's Street, London.

Walcott, C.D. 1884. Paleontology of the Eureka District. Monographs of the United States Geological Survey, 8:1-298.

Waller, T.R. 1990. The evolution of ligament systems in the Bivalvia, p. 49-71. In Morton, B. (ed.), The Bivalvia - Proceedings of a Memorial Symposium in Honour of Sir Charles Maurice Yonge, Edinburgh, 1986. Hong Kong University Press, Hong Kong.

Waller, T.R. 1998. Origin of the molluscan class Bivalvia and a phylogeny of major groups, p. 147. In Johnston, P.A. and Haggart, J.W. (eds.), Bivalves - An Eon of Evolution, Paleobiological Studies Honoring Norman D. Newell. University of Calgary Press, Alberta, Canada.

Walton, K. 2015. New Zealand living Solemyidae (Bivalvia: Protobranchia). Molluscan Research, 35(4):246-261. https://doi.org/10.1080/13235818.2015.1053168

Wanless, H.R. 1958. Pennsylvanian faunas of the Beardstown, Glasford, Havana, and Vermont Quadrangles. Illinois State Geological Survey, Report of Investigations, 205:1-59.

Waterhouse, J. B. 1969. The Permian bivalve genera Myonia, Megadesmus, Vacunella and their allies, and their occurrence in New Zealand. Palaeontological Bulletin, New Zealand Geological Survey, 41:1-141.

White, C.A. and Whitfield, R.P. 1862. Observations upon the rocks of the Mississippi Valley which have been referred to the Chemung Group of New York, together with descriptions of new species of fossils from the same horizon at Burlington, lowa. Proceedings of the Boston Society of Natural History, 8:289-306.

Williams, H.S. and Breger, C.L. 1916. The fauna of the Chapman Sandstone of Maine, including descriptions of some related species from the Moose River Sandstone. United States Geological Survey, Professional Paper, 89:1-347. https://doi.org/10.3133/pp89

Wilson, R.B. 1959. Wilkingia gen. nov. to replace Allorisma for a genus of upper Palaeozoic lamellibranchs. Palaeontology, 1(4):401-404.

Worthen, A.H. 1884. Descriptions of two new species of Crustacea, fifty-one species of Mollusca, and three species of crinoids, from the Carboniferous formation of Illinois and adjacent states. Bulletin, Illinois State Museum of Natural History, 2:1-32.

Worthen, A.H. 1890. Description of fossil invertebrates. Geological Survey of Illinois, 8(2):69154.

Zardus, J.D. 2002. Protobranch bivalves. Advances in Marine Biology, 42:1-65. https://doi.org/10.1016/S0065-2881(02)42012-3

Zhang, R. 1977. Bivalvia. Palaeontological Atlas of South-Central China, 2:471-533.

Zhang, R. and Pojeta, J. Jr. 1986. New bivalves from the Datang Stage, Lower Carboniferous, Guangdong Province, China. Journal of Paleontology, 60(3):669-679. https://doi.org/10.1017/S0022336000022198

Zittel, K. von 1913. Textbook of Paleontology, Charles R. Eastman, ed. Volume 1. MacMillan and Co., Ltd., St. Martin's Street, London. 